\title{
Old Wine in New Bottles?
}

\author{
Reassessing the Effects of Globalization on Political Preferences in \\ Western Europe
}

\begin{abstract}
In both public and scholarly debates, globalization has recently been accredited with a massive impact on the political preferences and electoral behaviour of Western citizens. Some go as far as to declare a new cleavage between winners and losers of globalization driven, e.g., by individuals' exposure to international competition and their degree of national as opposed to cosmopolitan identification. Extant tests of this argument have, however, relied on class and education as proxies for these processes. In contrast, this study provides the first direct test of the influence of the globalization processes on attitudes to economic distribution, the EU and immigration as well as on vote choice across nine West European countries. The results show that variables tapping the core aspects of globalization have relatively little impact on attitudes and vote choice; are largely unable to account for the effects of class and education; and do not seem to lead to the establishment of new divisions between winners and losers within or across classes. Rather, the winners and losers of globalization seem to be the traditional winners and losers with respect to material positions and political influence in modern Western societies, i.e. those placed higher as opposed to lower in the class and education hierarchies. In this way, the proposed cleavage between winners and losers of globalization may seem to be rather much like old wine in new bottles.
\end{abstract}




\section{Introduction}

Globalization is in many ways the buzzword of the $21^{\text {st }}$ century and is often hailed or blamed for cultural, economic, and political changes all over the world. In the political sphere, globalization is also considered to have a massive impact on the political preferences and electoral behaviour of Western citizens. Some go as far as to declare a new cleavage between winners and losers of globalization, on par with or even replacing the old cleavages related to class or religion. Recent electoral events in the West seem to support this picture. Both Donald Trump's victory in the US presidential election in 2016 and the Brexit vote have been seen in this light just as globalization played a role in the debate leading up to the 2017 presidential elections in France. Free trade, immigration, and globalization surely have been high on the agenda in the West recently.

In this paper, we first present the innovative and much-cited argument made by Kriesi et al. $(2006 ; 2008 ; 2012)$ that there is in the $21^{\text {st }}$ century a new cleavage between winners and losers of globalization, taking over for important cleavages of the $20^{\text {th }}$ century. Second, we argue that there have been important flaws in former empirical tests of this argument. In particular, it is unclear whether the development is really driven by the purported globalization processes - or if we are, instead, experiencing a revival and/or strengthening of well-known individual-level processes related to class and education. To ameliorate these flaws we identify and use variables that directly tap the characteristics of the winners and losers as defined by Kriesi et al. We bring to bear, thus, measures of exposure to globalization as well as cosmopolitanism versus national identity. Thereby, we enable a focused test of the argument that it is these defining characteristics that drive voter reactions to globalization. Additionally, we extend the range of countries analysed from the six covered by Kriesi et al. (i.e. Austria, France, 
Germany, the Netherlands, Switzerland and the UK) to include also the three Scandinavian countries which, with their small and open economies, should be even more affected by globalization.

Our tests of observable implications of the globalization argument demonstrate that in Western Europe, variables tapping core aspects of globalization as defined by Kriesi et al. are largely unable to account for the effects of class and education just as they do not seem to lead to the establishment of new divisions between winners and losers within classes. Rather, the winners and losers of globalization seem - to a very considerable degree - to be the traditional winners and losers with respect to material positions and political influence in modern Western societies, i.e. those placed higher as opposed to lower in the class and education hierarchies. In this way, the proposed cleavage between winners and losers of globalization may seem to be rather much like old wine in new bottles.

\section{Globalization: A new cleavage?}

In a series of carefully developed and analytically comprehensive works Kriesi et al. $(2006 ; 2008 ; 2012)$ argue that there is a new globalization cleavage structuring political conflict in Western Europe. The cleavage was induced by economic, cultural, and political globalization processes that benefited some segments of society and put others at a disadvantage (Kriesi et al. 2006: 922). Specifically, the globalization model posits three interrelated processes creating groups of winners and losers. Economically, increased competition creates losers among those who work in previously sheltered private - sectors that now become open to international competition. This group cuts across traditional class distinctions. 
Second, Kriesi et al. (2008: 5) emphasise that an essential criterion for distinguishing losers and winners is whether someone possesses exit options or not. This is tightly connected to levels of marketable skills (Kriesi et al. 2008: 7). Culturally, third, increased immigration of people from ethnically diverse origins into Western Europe creates a threat to cultural mores, perceptions, and traditions of some members of the majority populations. Likewise, increased EU-integration creates a threat to those strongly identified with their nation state - they become losers (Kriesi et al. 2008: 6-8).

At all three levels, those who have the opposite configuration can be considered winners. In short, the winners are seen to be entrepreneurs and qualified employees in sectors open to international competition, as well as all cosmopolitan citizens. Losers of globalization, by contrast, include entrepreneurs and qualified employees in traditionally protected sectors, all unqualified employees, and citizens who strongly identify themselves with their national community (Kriesi et al. 2008: 8).

In addition to their national identity, thus, globalization losers and winners are, in the parlance of political economy, defined based both on their factor endowments (class and education) as in the Heckscher-Ohlin and Stolper-Samuelson models and their sector (i.e. how open it is to international competition) as in the Ricardo-Viner model (cf. Walter and Maduz 2009). The authors predict that, relative to the winners, losers of globalization will be more in favour of redistribution, as this to some extent protects them against the negative economic impact of globalization. They further predict that losers will be more against the EU (which they consider to be the prime symbol of political globalization for Europeans) and more against immigration - all relative to winners of globalization (Kriesi et al. 2012: 12-16). Moreover, winners and losers are expected to vote in accordance with their attitudes, i.e. for parties articulating 
programmes appealing to their preferences. In particular, globalization losers are expected to vote for populist right parties (Kriesi et al. 2008: 18-9).

While the work of Kriesi and his colleagues is theoretically innovative and highly stimulating, on closer inspection the empirical tests turn out to be somewhat problematic. In spite of the relatively clear identification of the theoretical mechanisms, the authors later state that 'social class as well as the level of education are the most important features distinguishing between winners and losers of globalization' (Kriesi et al. 2008: 61). Class and education are therefore used as measures of voters' positions in relation to the proposed new cleavage - as proxies for the variables discussed above. The argument for this approach is, in short, that people in higher classes or with higher education have 'specialized skills which are marketable inside and across the national boundaries, thus considerably increasing one's exit options' (Kriesi et al. 2008: 7).

In the empirical test, then, position in the globalization cleavage depends on an individual's factor endowments alone: The losers are people with low education and in 'lower' classes, while people with high education and in 'higher' social classes are the winners. For the countries included in the analysis, this amounts, essentially, to a test of the Heckscher-Ohlin or Stolper-Samuelson theorem, which predicts that globalization benefits those owning factors of production with which their economy is relatively well endowed (i.e. those with high skill levels in advanced economies), while hurting those owning scarcer factors (i.e. lower skills; see Hainmueller and Hiscox 2006: 470).

Although understandable for both theoretical (class and education are likely related to the core variables) and practical (i.e. data availability) reasons, this analytical approach is unfortunate. It prevents an assessment of the core theoretical elements of the globalization explanation. First, the empirical strategy does not allow us to distinguish between processes that are actually related to globalization, and processes 
that are related to the old and well-known cleavages over class and education. While the class schema Kriesi et al. use (a modified version of Daniel Oesch's (2006) class schema) is likely to be somewhat correlated with exposure to international competition, it is far from a direct measure of it. Second, while both class and education may be correlated with national identity to some degree, they are not direct measures of cosmopolitanism versus national identity (we substantiate these points below). Third, although education and class are correlated with marketable skills, they are again no direct measures. Further, skills is also a core aspect of traditional conceptions of class and education (e.g. Erikson and Goldthorpe 1992, Oesch 2006, see also Atkinson 2015, Braun and Müller 1997). Using a class schema to measure skills makes it impossible, therefore, to isolate that part of the effect of class that is unique to the globalization model from that which is due to what is traditionally seen to be the effects of class and education.

Consequently, the otherwise impressive evidence amassed by Kriesi et al. to support their conclusion only seems to provide indirect support for the existence of a globalization cleavage as something qualitatively different from cleavages over class and education.

Specifically, Kriesi and co-authors find that the unskilled workers are more economically left-wing, more anti-EU and more anti-immigration than socio-cultural specialists; they find the same for those with lower education compared to those with higher (Kriesi et al. 2008: ch. 10). While we do not dispute these results - indeed we replicate them below - what we question is their implications with respect to the globalization cleavage hypothesis. The results would seem to also accord with those of 
other analyses ${ }^{1}$ conducted from more traditional perspectives focused on the influence of class and education rather than globalization. In such accounts, the central mechanisms generating conflict between the groups are related to, for class, redistribution of wealth, income, and job security (cf., e.g., Lipset 1991: 208; Evans and de Graaf 2013: viii) and, for education, conflicting values grounded in, among other factors, different socialization experiences (cf., e.g., Lipset 1981; Stubager 2008, see also Hainmueller and Hiscox 2006).

Second, as noted the empirical strategy essentially reflects a factor-endowments model (see e.g. Stolper and Samuelson 1941, Findlay and Kierzkowski 1983), which predicts a class-based distributional conflict where high-skilled individuals are winners of globalization, whereas the low-skilled are losers (see Walter 2010: 410). This is in contrast to the theoretical argument, that also includes a (Ricardo-Viner type) sectoral component: Whether one is sheltered from international competition or not (see also Frieden and Rogowski 1996; Hays et al. 2005). In this way, the lack of empirical clarity spills over to the theoretical level in the sense that it becomes unclear who the winners and losers of globalization really are.

To put it pointedly, the analyses of Kriesi et al. seek to demonstrate the relevance of the alleged, new globalization cleavage against the traditional conflicts over class and education by using standard measures of the latter to represent the former and without taking into account the sectoral element of the purported new mechanism and its conditioning effects. With the extant set of analyses from Kriesi and his co-

\footnotetext{
${ }^{1}$ For class and left-wing attitudes see Lipset 1981; Svallfors 2006; class and EU-attitudes, see Gabel 1998; Gabel and Palmer 1995; Hix 2005; class, education and immigration-attitudes, see Coffé 2013; Dancygier and Walter 2015; Oesch 2008; Oskarson and Demker 2013; Stubager 2008.
} 
authors it is, therefore, not clear that the hypothesis regarding a new cleavage is supported: The results could just as easily be interpreted as indicating the continued maybe even renewed - influence of class and education and the processes associated with them. In essence, thus, while we agree with Kriesi et al. that class and education are important predictors of political behaviour in modern Western societies, we question whether this relationship reflects the processes suggested by the authors.

\section{Testing the Globalization Model}

To approach a better understanding of the processes at work, in this article, we aspire to subject the model of political behaviour that Kriesi et al. develop (henceforth the globalization model) to a more valid test. We do this by testing two observable implications pertaining to the core processes of the globalization model. First, we focus on the influence of the economic aspect of globalization: increased international competition. As noted, Kriesi et al. see such competition as a key aspect of the globalization model and suggest that those exposed to it - i.e. the losers of globalization - will react politically as described above. If class and education are proxies for such experiences, it means that a direct measure hereof should account for a considerable part of the effect of class and education on attitudes and vote choice.

This also applies for individuals' degree of national identity. Those who are strongly attached to their nation state are seen as losers of the globalization process that dissolves the boundaries between such states. To the extent that class and education are proxies for such identities as is assumed in the modelling of Kriesi et al., we should like for exposure to international competition - find that including a direct identity measure will reduce the effect of class and education on the attitude and party choice variables. Our first hypothesis, then, is that direct measures of exposure to international 
competition as well as strength of national identity should account for a considerable part of the effect of class and education on attitudes and party preference (H1).

Second, according to Kriesi et al. (2008: 6), the increased international competition affects individuals across traditional class boundaries resulting in 'crossclass coalitions'. This implies that we should see an interaction between individuals' class location and their exposure to international competition such that class differences diminish or disappear among those negatively affected by globalization. This is $\mathrm{H} 2$.

However, and related to the point regarding the lack of theoretical clarity of the globalization model, the effects of globalization may be more nuanced. Thus, based on work in trade theory and combining a sectoral and factoral approach Walter and Maduz (2009; see also Walter 2017) argue that the losers of globalization are those low-ability individuals who are exposed to international competition, because they are most at risk of losing their job and receiving low wages. Conversely, highly productive individuals who are exposed to international competition receive higher wages and can be characterized as globalization winners. In between these two extremes, low ability workers in sectors that are sheltered from international competition are better off than their counterparts in the exposed industries, but are worse off than the high-ability employees in the sheltered industries. According to this view, exposure to international competition has different effects for members of different classes.

Evidence of such a heterogeneous effect of globalization on political behaviour has been found for preferences regarding the welfare state (Walter 2010), income inequality (Walter 2017) and immigration policy (Dancygier and Walter 2015) as well as for party choice (Rommel and Walter 2018). Following this logic, we should, as for $\mathrm{H} 2$, expect to find an interaction between individuals' class location and their exposure to international completion. But contrary to $\mathrm{H} 2$ we would expect the lower classes to 
react negatively towards globalization when exposed to it, while the higher classes react positively when exposed to globalization. To provide a more encompassing test of the mechanisms associated with globalization, we test this argument as H3.

We examine these implications with respect to two elements both seen as central to the cleavage model of politics: political attitudes and party preference. Thus, we examine, first, the extent to which the implications are supported with respect to economic left-right, EU-, and immigration attitudes. These are the three kinds of political attitudes that globalization should be particularly relevant for, according to Kriesi et al. (2008: 5-8). Second, we investigate the degree of support for the expectations with respect to party preference, which has been the central way of measuring cleavages for decades.

We should underline that we do not purport to investigate all possible implications of the globalization model, neither as laid out by Kriesi and colleagues, nor in the political economy literature. But we do look into a set of relevant processes that seem to follow directly from the core argument of Kriesi et al. The analyses will, consequently, provide a first indication of the tenability of the globalization model as compared to more traditional class- and education-based oppositions.

\section{Data and Methodology}

To test our hypotheses, we use the latest version of the European Values Study (EVS) at the time of writing, i.e. from 2008-2010. As the only cross-national data set, the EVS contains the variables required to test the various models: 1) Several nuanced measures of economic left-right, EU, and immigration attitudes in addition to party preference, and 2) information necessary for constructing our independent and control variables. In 
total, we bring to bear evidence based on 8,084 respondents from nine countries. ${ }^{2}$

The countries comprise the six original cases from the studies of Kriesi et al. Austria, France, Germany, the Netherlands, Switzerland and the UK - as well as the three Scandinavian countries, Denmark, Norway and Sweden. This choice is based on two considerations. First, the use of the six original cases permits a replication of the analyses of Kriesi and his co-authors just as it holds constant country specific factors that might otherwise confound the analyses. Second, the inclusion of the three Scandinavian countries extends the test of the arguments to a set of cases for which the mechanisms underlying the globalization hypothesis should be particularly strong. Given their small, open economies, thus, the Scandinavian countries are highly susceptible to the influence of international competition. They may, therefore, be seen as critical cases for the globalization hypothesis - i.e. as cases in which globalization should have particularly strong impact.

\section{The independent variables}

We start out with the variables used by Kriesi et al.: class and education. The former is measured by a standard six-class version of the traditional EGP occupational class measure (Erikson et al. 1979; Erikson and Goldthorpe 1992: ch. 2. In our model, we operate with the following classes: unskilled workers, skilled workers, routine nonmanual employees, petite bourgeoisie, and the lower and higher service class. ${ }^{3}$ Second like Kriesi et al. (2008: 64), we use a standard education variable with three groups:

\footnotetext{
${ }^{2}$ For reasons discussed below, we furthermore replicate the results using the first two rounds of the European Social Survey, see the appendix.

${ }^{3}$ We have also estimated all models using instead the class schema developed by Oesch (2006); the results (available from the authors upon request) are essentially the same as those reported below. This is in line with recent evidence that the two class schemas have similar explanatory power across time (Vestin and Oskarson 2017) and space (Knutsen and Langsæther 2016).
} 
'lower' (i.e. pre-primary, primary or lower secondary education), 'medium' (upper or post-secondary education) and 'higher' (first or second stage of tertiary education).

To conduct a more direct test of the globalization model, we use measures focusing on the processes through which globalization is argued to affect people's life situation. The first is exposure to globalization. This is traditionally measured in three different ways in the political economy literature: Whether the sector an individual works in is tradable or non-tradable (e.g. Hays et al. 2005); the degree to which the sector is exposed to foreign direct investment (e.g. Scheve and Slaughter 2004); and finally, the degree to which an individual's occupation is offshorable. Offshoring - the movement of employment from one country to another - is an aspect of globalization that has accelerated rapidly over the last decades (Rommel and Walter 2018) and it is the measure that we focus on in the main analyses below.

We do so for two reasons. First, it has been argued forcefully that political preferences are "shaped much more" (Walter 2017: 63) by occupational risks than by sectoral risks, as it is easier for an individual to change his or her sector of employment than to change occupation (Iversen and Soskice 2001; Cusack et al. 2006; Rehm 2009). The measure is expected, therefore, to capture the pressure of globalization felt by individuals much better than sectoral measures. Second, it allows us to use the nuanced measures of the dependent variables in the EVS, which contains occupational data on the respondents, but unfortunately, no data on the industrial sectors in which they are employed.

However, because this is an important point in the theoretical discussion (cf. above) and to make sure that this choice does not affect our results, we have replicated the entire set of analyses as closely as possible, using the first two waves of the European Social Survey (ESS). While not all measures used below are available in the 
ESS, it allows us to include a measure of whether the individual is working in a tradeable or sheltered sector, in addition to the offshorability of their jobs. These analyses of a different data set show the same overall results as do the EVS data and we have, for this reason and due to space restrictions, placed them in the appendix. ${ }^{4}$

Following recent work in the political economy field (e.g., Dancygier and Walter 2015, Walter 2017, Rommel and Walter 2018) we use Blinder's (2009) offshorability index to assess the extent to which a person's job is offshorable. Clearly, the more easily your job can be offshored, the more exposed you are to international competition. The index is based on ISCO codes of respondents' jobs. It 'measures whether the service the job provides can theoretically be delivered over long distances with little or no degradation in quality' (Dancygier and Walter 2015: 137). The index ranges between 0 and 100 where a low value indicates that the job is hard or impossible to move out of the country and a high value indicates that the job is easily offshorable. For example, childcare has a value of zero because it requires close physical contact, while data entry keyers perform activities that are clearly offshorable and are thus assigned a value of 100 (Blinder 2009: 51-52). We transform the index to 0-10 for ease of interpretation (see the appendix for descriptive statistics for all variables). ${ }^{5}$

Second, we measure people's degree of identification with their national community as opposed to a more cosmopolitan identity. To construct this variable, we rely on a question where respondents were asked which geographical group they 'first

\footnotetext{
${ }^{4}$ Likewise, we have replicated the analyses using yet another measure of globalization exposure from Walter (2017), namely whether the sector is import-competing or export-oriented, based on revealed comparative (dis)advantage. These analyses yield essentially the same results as those presented and are available from the authors on request.

${ }^{5} \mathrm{We}$ also run all models with a dichotomous version of this variable. This does not alter any of the substantial conclusions, see the appendix.
} 
and foremost' belong to, and then which they 'secondly' belong to. They could choose between their town/local area, region, country, Europe, and the world. Respondents who place their country first, and their local or regional belonging second, or the other way around, are considered to possess a primarily national identity. Respondents who place Europe or the world first, are cosmopolitans. Respondents who either place their country, local area, or region first, and Europe or the world second, are considered to be in an intermediate position. ${ }^{6}$ This measure is used to test the part of the first hypothesis related to national identity versus cosmopolitan orientations. In all models, we control for age, gender, and urban-rural residence.

\section{The dependent variables}

Party preference is operationalised through a question of vote intention in the EVS. Like Kriesi et al. (2012), we distinguish between seven party families: Communists/Left Socialists, Social Democrats, Greens, Liberals, Christian Democrats and Conservatives, the Populist Right, and other parties (including EU protest parties). We follow Kriesi et al.'s (2012: 52-53) categorisation of the various parties for the six original countries, and extend the categorization to the three Scandinavian countries (see the appendix for a complete overview).

Economic left-right attitudes are measured by asking for the respondent's views on individual versus state responsibility, economic freedom, income inequality versus incentives, private versus public incentives, and competition. Following the work of Knutsen (2017) and Langsæther (2018) responses to these five items are combined into an index of economic left-right attitudes ranging from 0 to 10 . Higher values on the

\footnotetext{
${ }^{6}$ As a robustness check, the appendix includes analyses where we instead employ a variable measuring how proud the respondent is to be a citizen of the country. As can be seen, the results are robust to this change.
} 
index indicate left-wing positions (see the appendix for details on the scale construction).

EU attitudes are measured by respondents' responses to a number of items about fears they might have about the EU membership, like loss of social security, power, jobs, national identity/culture, as well as growth in EU-expenses for their own country. Responses to these items are combined and rescaled to the 0-10 range with higher values indicating more fear of the EU. ${ }^{7}$

Finally, for immigration attitudes we again use an index developed by Knutsen (2017). The index is based on questions related to how the respondent feels about immigration and immigrants. Are they seen as a cultural threat, should they maintain or abandon their customs and traditions, are they a strain on the welfare system or not, etc. The summated scale goes from 0 to 10 with higher values indicating more immigration positive attitudes. The multiple indicators used here represent an important improvement on extant research on globalization and political preferences (e.g., Dancygier and Walter 2015) which has mainly relied on single indicators.

\section{Methodology and models}

To assess our research question about the implication of globalization processes for cleavage development in Western Europe we run four (OLS or multinomial logistic) regression models for each dependent variable. In the first model, we include class and education in addition to the control variables. ${ }^{8}$ The model, thus, can be seen as a baseline model intended to replicate the analyses of Kriesi et al.

\footnotetext{
${ }^{7}$ These items were not asked in Norway, which is not a member of the EU. For this reason Norway is excluded from analyses of this specific attitude dimension.

${ }^{8}$ The tables below only show the coefficients of interests. Full tables are available in the appendix A.7.
} 
Our second model contains only the controls and the measures of offshorability and national identity in order to establish the existence of a relationship between the two globalization variables and the outcomes as a preliminary step before estimating the third model which combines class and education with the two globalization variables. By comparing results from this model with those from the first model containing only class and education (and the controls) we can, hence, evaluate H1 which suggest that the effects of class and education is reduced when the variables are included in the same model as offshorability and national identity. Finally, in the fourth model we interact the offshorability and class measures to test $\mathrm{H} 2$ and $\mathrm{H} 3$ about the existence of an interaction effect between class and exposure to international competition.

All models are run on a pooled data set comprising all observations. In addition, all the analyses of political attitudes are run in each of the nine countries individually. In the discussion below, focus will be on the former, although we will also comment on the country-specific results (which are presented in the appendix). In the pooled models we include country fixed effects to account for any country specific variation not captured by our independent variables.

\section{Results}

Before launching into the main analyses, it is worth noting that there is only a weak relationship between the two sets of independent variables in our analysis. Thus, as can be seen in Table A.1.7 in the appendix, there are only small differences with respect to offshoreability between the classes and educational groups. The same applies for cosmopolitanism although it is moderately related to education. These results substantiate our critique of Kriesi et al.'s use of class and education as proxies for the globalization processes just as they raise initial doubts about H1. If there is only a weak 
to moderate relationship between class and education and the globalization variables, it seems less likely that the latter mediate the effect of the former on our dependent variables. The discussion below, ordered according to the dependent variables, throws light on exactly this.

\section{Economic left-right attitudes}

Table 1 shows the results of the pooled OLS regression analysis of economic left-right attitudes. In Model 1 we see clear differences between both groups of workers and all the other classes, with the largest differences opening up between workers and the higher service class and the petite bourgeoisie - exactly as a traditional class approach would predict. Furthermore, class seems to be a much stronger predictor of left-right attitudes than education - again a result that comports with traditional models.

Model 2 shows that the globalization variables are also related to economic attitudes. But for both variables we find the opposite result of what the globalization model predicts: Those exposed to offshorability and with a strong national identity (i.e. the losers of globalization) and the most fiscally right-wing. 
Table 1. Explaining economic left-right attitudes. OLS.

\begin{tabular}{|c|c|c|c|c|}
\hline & $\begin{array}{c}1 \\
\text { Class and } \\
\text { education }\end{array}$ & $\begin{array}{c}2 \\
\text { Globalization } \\
\text { variables }\end{array}$ & $\begin{array}{c}3 \\
\text { Combined } \\
\text { model }\end{array}$ & $\begin{array}{c}4 \\
\text { Interaction } \\
\text { model }\end{array}$ \\
\hline Class:Hi.serv. & $\begin{array}{c}-0.78^{* * *} \\
(0.07)\end{array}$ & & $\begin{array}{c}-0.74^{* * *} \\
(0.07)\end{array}$ & $\begin{array}{c}-0.74^{* * *} \\
(0.09)\end{array}$ \\
\hline Class:Lo.serv. & $\begin{array}{c}-0.44^{* * * *} \\
(0.07)\end{array}$ & & $\begin{array}{c}-0.40^{* * *} \\
(0.07)\end{array}$ & $\begin{array}{c}-0.32^{* * *} \\
(0.08)\end{array}$ \\
\hline Class:Rout.nman & $\begin{array}{c}-0.19^{* * *} \\
(0.06)\end{array}$ & & $\begin{array}{c}-0.17^{* * *} \\
(0.06)\end{array}$ & $\begin{array}{l}-0.14^{*} \\
(0.07)\end{array}$ \\
\hline Class:Petite bourg. & $\begin{array}{c}-0.99^{* * *} \\
(0.09)\end{array}$ & & $\begin{array}{c}-0.94^{* * *} \\
(0.09)\end{array}$ & $\begin{array}{c}-0.93^{* * *} \\
(0.13)\end{array}$ \\
\hline Class:Skilled workers & $\begin{array}{l}-0.06 \\
(0.07)\end{array}$ & & $\begin{array}{l}-0.04 \\
(0.07)\end{array}$ & $\begin{array}{l}-0.10 \\
(0.08)\end{array}$ \\
\hline Education:Medium & $\begin{array}{c}-0.18^{* * *} \\
(0.05)\end{array}$ & & $\begin{array}{c}-0.17^{* * *} \\
(0.05)\end{array}$ & $\begin{array}{c}-0.17^{* *} \\
(0.05)\end{array}$ \\
\hline Education:Higher & $\begin{array}{l}-0.13^{*} \\
(0.06)\end{array}$ & & $\begin{array}{l}-0.15^{*} \\
(0.06)\end{array}$ & $\begin{array}{l}-0.15^{*} \\
(0.06)\end{array}$ \\
\hline Nat.ID:Intermediate & & $\begin{array}{c}0.01 \\
(0.05)\end{array}$ & $\begin{array}{c}0.07 \\
(0.05)\end{array}$ & $\begin{array}{c}0.07 \\
(0.05)\end{array}$ \\
\hline Nat.ID:Cosmopolitan & & $\begin{array}{l}0.22^{* * *} \\
(0.06)\end{array}$ & $\begin{array}{c}0.25^{* * *} \\
(0.06)\end{array}$ & $\begin{array}{l}0.26^{* * *} \\
(0.06)\end{array}$ \\
\hline Offshorability & & $\begin{array}{c}-0.04^{* * *} \\
(0.01)\end{array}$ & $\begin{array}{c}-0.02^{* * *} \\
(0.01)\end{array}$ & $\begin{array}{l}-0.01 \\
(0.02)\end{array}$ \\
\hline Hi.serv.xOffshorability & & & & $\begin{array}{l}-0.01 \\
(0.02)\end{array}$ \\
\hline Lo.serv.xOffshorability & & & & $\begin{array}{l}-0.03 \\
(0.02)\end{array}$ \\
\hline Rout.nmanxOffshorability & & & & $\begin{array}{l}-0.02 \\
(0.02)\end{array}$ \\
\hline Petite bourg.xOffshorability & & & & $\begin{array}{l}-0.01 \\
(0.03)\end{array}$ \\
\hline Skilled w.xOffshorability & & & & $\begin{array}{c}0.03 \\
(0.03)\end{array}$ \\
\hline Controls and constant & $\mathrm{X}$ & $\mathrm{X}$ & $X$ & $\mathrm{X}$ \\
\hline
\end{tabular}

Adjusted $R^{2}$
Note: ${ }^{*} p<0.05,{ }^{* *}: p<0.01,{ }^{* * *}: p<0.001 . \mathrm{N}=8,084$. Reference categories: Class: unskilled workers; Nat. ID:
Strong national identity; Education: lower. Standard errors in parentheses.


Combining the globalization variables with class and education in Model 3 permits a test of $\mathrm{H} 1$, which argues that the effects of class and education will be substantially reduced - maybe even disappear - when placed alongside variables tapping into the globalization process. As is evident from the table, the effects of class and education are almost unchanged between Model 1 and 3. This means that the hypothesis will have to be rejected. ${ }^{910}$ The same applies to $\mathrm{H} 2$ and $\mathrm{H} 3$, which are tested in Model 4. All of the individual interaction terms as well as all of them together $(F=1.5, p=.19)$ are insignificant just as the increase in the adjusted $R^{2}$ is marginal (0.001). We see no sign, that is, of globalization-based cross-class alliances forming: Class differences are not smaller among those exposed to globalization than among those not so exposed (H2). Furthermore, people in higher classes do not become more right-wing when exposed to globalization, and people in lower classes do not become more left-wing (H3). We should note, however, that when interacting education, rather than class, with offshorability there is one statistically significant interaction term: Those with the highest level of education are somewhat more right-wing when exposed to globalization compared to those not so exposed. ${ }^{11}$ This counts against $\mathrm{H} 2$ which

\footnotetext{
${ }^{9}$ In addition, we use the KHB method (Breen et al. 2013) to test the extent of mediation of the class and education effects by the two globalization variables. Except for one coefficient in one model, these tests were insignificant, hence rejecting the mediation expectation. Thus, and because the one significant coefficient was only affected marginally we conclude that the test showed no noteworthy sign of mediation.

${ }^{10}$ Since we can also note that the effects of the globalization variables do not change much from Model 2 to Model 3, while the $R^{2}$ increases, it would seem that the two sets of variables are reflecting rather separate causal processes in the formation of left-right economic attitudes $-\mathrm{a}$ point to which we return below.

${ }^{11}$ The results are available from the authors on request. We find a similar pattern in the analyses of the ESS-data.
} 
therefore has to be rejected, but the result provides some support for $\mathrm{H} 3$ (cf. Walter $2010 ; 2017)$ - a point to which we will return in the conclusion.

We have also tested the hypotheses in each country individually (see the appendix). In eight out of the nine countries, there is no support for $\mathrm{H} 1$ : The class and education coefficients do not change substantially after introducing controls for the globalization variables. Only in Denmark a small change is detectable for two classes. There is also no support for $\mathrm{H} 2$ or $\mathrm{H} 3$ in eight out of the nine countries with only minor effects showing up for a few class categories in France. Furthermore, the variables used to directly tap the globalization processes fare no better in the Scandinavian countries than in the other six, despite the open economies of the former: While the globalization variables on average explain $4 \%$ of the variance in economic left-right attitudes in the original six countries, they explain on average 5\% in the Scandinavian countries.

As far as regards economic left-right attitudes, thus, our tests have not been encouraging for the globalization perspective. While class and education are related to the attitudes in the expected way, this association does not seem to be driven by the globalization processes. Rather, the relationship conforms to what traditional models would predict. There is no evidence of cross-class alliances and no evidence of classes reacting differentially to globalization.

\section{EU attitudes}

Turning to the analysis of EU attitudes in Table 2, we see a rather similar picture. ${ }^{12}$ Both class and education (the latter more strongly so than in Table 1) are related to EU attitudes in the expected direction - i.e. those with higher levels of education or placed

\footnotetext{
${ }^{12}$ Recall, that Norway is not included in this analysis. Hence, the $\mathrm{N}$ in the table is lower than for the other analyses.
} 
higher up in the class hierarchy are more sympathetic to the EU.

Table 2: Explaining EU attitudes. OLS.

\begin{tabular}{|c|c|c|c|c|}
\hline & $\begin{array}{c}1 \\
\text { Class and } \\
\text { education }\end{array}$ & $\begin{array}{c}2 \\
\text { Globalization } \\
\text { variables }\end{array}$ & $\begin{array}{c}3 \\
\text { Combined } \\
\text { model }\end{array}$ & $\begin{array}{c}4 \\
\text { Interaction } \\
\text { model }\end{array}$ \\
\hline Class:Hi.serv. & $\begin{array}{c}-0.85^{* * *} \\
(0.12)\end{array}$ & & $\begin{array}{c}-0.74^{* * *} \\
(0.12)\end{array}$ & $\begin{array}{c}-0.74^{* * *} \\
(0.14)\end{array}$ \\
\hline Class:Lo.serv. & $\begin{array}{c}-0.65^{* * *} \\
(0.11)\end{array}$ & & $\begin{array}{c}-0.52^{* * *} \\
(0.11)\end{array}$ & $\begin{array}{c}-0.58^{* * *} \\
(0.13)\end{array}$ \\
\hline Class:Rout.nman & $\begin{array}{c}-0.34^{* *} \\
(0.11)\end{array}$ & & $\begin{array}{c}-0.28^{* * *} \\
(0.11)\end{array}$ & $\begin{array}{c}-0.34^{* * *} \\
(0.12)\end{array}$ \\
\hline Class:Petite bourg. & $\begin{array}{c}-0.64^{* * *} \\
(0.15)\end{array}$ & & $\begin{array}{c}-0.59^{* * *} \\
(0.15)\end{array}$ & $\begin{array}{l}-0.65^{* *} \\
(0.20)\end{array}$ \\
\hline Class:Skilled workers & $\begin{array}{c}0.10 \\
(0.13)\end{array}$ & & $\begin{array}{c}0.07 \\
(0.12)\end{array}$ & $\begin{array}{c}0.04 \\
(0.14)\end{array}$ \\
\hline Education:Medium & $\begin{array}{c}-0.35^{* * *} \\
(0.09)\end{array}$ & & $\begin{array}{c}-0.37^{* * * *} \\
(0.09)\end{array}$ & $\begin{array}{c}-0.38^{* * * *} \\
(0.09)\end{array}$ \\
\hline Education:Higher & $\begin{array}{c}-1.41^{* * *} \\
(0.10)\end{array}$ & & $\begin{array}{c}-1.32^{* * *} \\
(0.10)\end{array}$ & $\begin{array}{c}-1.32^{\text {**** }} \\
(0.10)\end{array}$ \\
\hline Nat.ID:Intermediate & & $\begin{array}{c}-0.95^{* * *} \\
(0.08)\end{array}$ & $\begin{array}{c}-0.75^{* * *} \\
(0.08)\end{array}$ & $\begin{array}{c}-0.75^{* * *} \\
(0.08)\end{array}$ \\
\hline Nat.ID:Cosmopolitan & & $\begin{array}{c}-1.57^{* * *} \\
(0.09)\end{array}$ & $\begin{array}{c}-1.38^{* * *} \\
(0.09)\end{array}$ & $\begin{array}{c}-1.38^{\text {**** }} \\
(0.09)\end{array}$ \\
\hline Offshorability & & $\begin{array}{c}-0.05^{* * *} \\
(0.01)\end{array}$ & $\begin{array}{l}-0.02^{*} \\
(0.01)\end{array}$ & $\begin{array}{l}-0.05 \\
(0.03)\end{array}$ \\
\hline Hi.serv.xOffshorability & & & & $\begin{array}{c}0.01 \\
(0.04)\end{array}$ \\
\hline Lo.serv.xOffshorability & & & & $\begin{array}{c}0.04 \\
(0.04)\end{array}$ \\
\hline Rout.nmanxOffshorability & & & & $\begin{array}{c}0.04 \\
(0.04)\end{array}$ \\
\hline Petite bourg.xOffshorability & & & & $\begin{array}{c}0.04 \\
(0.05)\end{array}$ \\
\hline Skilled w.xOffshorability & & & & $\begin{array}{c}0.03 \\
(0.04)\end{array}$ \\
\hline Controls and constant & $\mathrm{X}$ & $\mathrm{x}$ & $\mathrm{x}$ & $\mathrm{X}$ \\
\hline Adjusted $R^{2}$ & 0.149 & 0.126 & 0.188 & 0.188 \\
\hline
\end{tabular}

Note: ${ }^{*} p<0.05,{ }^{* * *} p<0.01,{ }^{* * *} p<0.001 . \mathrm{N}=6,935$. Reference categories: Class: unskilled workers; Nat. ID: Strong national identity; Education: lower. Standard errors in parentheses.

Unsurprisingly, Model 2 shows that whether individuals identify with their nation or have a more cosmopolitan self-conception is rather strongly related to their EU-attitudes with cosmopolitans more positively disposed. Somewhat more surprisingly, however, those occupied in jobs exposed to international competition are 
more positive towards EU than those not so exposed. Combining the globalization variables with class and education in Model 3 only affects the influence of the latter minimally and all coefficients that were significant in Model 1 remain so in Model 3. This again leads to a rejection of $\mathrm{H} 1$. Turning to Model 4, finally, we can see that $\mathrm{H} 2$ and $\mathrm{H} 3$ will also have to be rejected since none of the interaction terms are significant just as the overall test comes out insignificant $(F=0.2, p=.96) .{ }^{13}$

At the country level, the class and education coefficients change only marginally or not at all when controlling for the globalization variables, thereby contradicting $\mathrm{H} 1$. As for $\mathrm{H} 2$ and $\mathrm{H} 3$, the formal, joint tests of the interaction coefficients all turn out insignificant meaning that we have to reject these hypotheses. Furthermore, the globalization variables explain on average $9 \%$ of the variation in the six original countries, and only $6 \%$ in the Scandinavian countries. For EU-attitudes, thus, these variables fare worst where the globalization model would have expected them to do best.

In sum and as was the case for left-right economic attitudes, the globalization variables seem unable to account for the effects of class and education on EU attitudes. These effects, in other words, do not appear driven by the processes suggested by Kriesi and co-authors; processes that seem, however, to also have some effect on individuals' EU-attitudes independently of class and education.

\section{Immigration attitudes}

As can be seen in Table 3, we generally find the same pattern of results with respect to immigration attitudes. Again, we note from Model 1 the well-known connections between class, education, and immigration attitudes.

\footnotetext{
${ }^{13}$ There is also no significant interaction between education and offshorability. The same applies for immigration attitudes and party choice.
} 
As expected by the globalization model, the estimates from Model 2 show those with a cosmopolitan identity to be the most positive towards immigration, but contrary to expectations based on the model - that also applies to those most subject to international competition. This effect, however, becomes insignificant in Model 3 when placed alongside class and education. And as was the case for the two other attitudinal variables, the effects of the two latter variables are left mainly unaffected by the inclusion of the globalization variables. Again, this leads us to reject $\mathrm{H} 1$ - the effects of class and education are not accounted for by the globalization processes. Model 4, finally, indicates that we also have to reject $\mathrm{H} 2$ and $\mathrm{H} 3$ : Neither the individual coefficients nor all of them together $(F=0.76, p=.58)$ are significant. There is thus no sign of cross-class alliances between the losers of globalization; nor is there any sign that those with lower skills react negatively to exposure while those with higher skills react positively.

Table 3: Explaining immigration attitudes. OLS.

\begin{tabular}{lcccc}
\hline & $\begin{array}{c}1 \\
\text { Class and } \\
\text { education }\end{array}$ & $\begin{array}{c}\text { Globalization } \\
\text { variables }\end{array}$ & $\begin{array}{c}\text { Combined } \\
\text { model }\end{array}$ & $\begin{array}{c}\text { Interaction } \\
\text { model }\end{array}$ \\
\hline Class:Hi.serv. & $0.44^{* * * *}$ & & $0.36^{* * * *}$ & $0.31^{* *}$ \\
& $(0.10)$ & & $(0.09)$ & $(0.11)$ \\
Class:Lo.serv. & $0.45^{* * *}$ & & $0.36^{* * *}$ & $0.45^{* * * *}$ \\
& $(0.09)$ & & $(0.09)$ & $(0.10)$ \\
Class:Rout.nman & $0.24^{* *}$ & & $0.20^{*}$ & $0.21^{*}$ \\
& $(0.09)$ & & $(0.08)$ & $(0.09)$ \\
Class:Petite bourg. & 0.01 & & -0.01 & -0.03 \\
& $(0.11)$ & & $(0.11)$ & $(0.15)$ \\
Class:Skilled workers & $-0.21^{*}$ & & -0.18 & -0.21 \\
& $(0.10)$ & & $(0.10)$ & $(0.11)$ \\
Education:Medium & & & & \\
& $0.28^{* * *}$ & & $0.30^{* * *}$ & $0.30^{* * * *}$ \\
Education:Higher & $(0.07)$ & & $(0.07)$ & $(0.07)$ \\
& $1.09^{* * *}$ & & $1.01^{* * * *}$ & $1.00^{* * * *}$ \\
& $(0.08)$ & & $(0.07)$ & $(0.07)$ \\
Nat.ID:Intermediate & & & & \\
Nat.ID:Cosmopolitan & & $0.79^{* * * *}$ & $0.66^{* * * *}$ & $0.66^{* * * *}$ \\
& & $(0.06)$ & $(0.06)$ & $(0.06)$ \\
& & $1.45^{* * *}$ & $1.32^{* * *}$ & $1.32^{* * * *}$ \\
& & $(0.07)$ & $(0.07)$ & $(0.07)$
\end{tabular}


Lo.serv.xOffshorability

\begin{tabular}{ccccc} 
Adjusted $R^{2}$ & $\mathrm{X}$ & $\mathrm{X}$ & $\mathrm{X}$ & $\mathrm{X}$ \\
\hline Note: & 0.150 & 0.150 & 0.199 & 0.199
\end{tabular}

Note: ${ }^{*} p<0.05,{ }^{* *}: p<0.01,{ }^{* * * *} p<0.001 . \mathrm{N}=8,084$. Reference categories: Class: unskilled workers; Nat. ID: Strong national identity; Education: lower. Standard errors in parentheses.

The country-specific analyses support this picture. First, we find no support for H1 in six out of nine countries while only smaller changes in the class (the UK) and education coefficients (Austria and France) can be observed after controlling for the globalization variables in the three remaining countries. $\mathrm{H} 2$ and $\mathrm{H} 3$ do not receive any support in eight of the countries, neither as judged by individual coefficients nor joint tests. And while the joint test comes out significant in France, the individual coefficients show an incoherent pattern. Finally, and again in contrast to the globalization perspective, the globalization variables account for $13 \%$ of the variation in the six original countries, and only $7 \%$ on average in the open economies of Scandinavia.

Summing up, therefore, we can conclude that the globalization model fails to meet the expectations based on the observable implications derived from it also for immigration attitudes. While at least one of the variables used to directly tap its effects is significant and provide additional explanatory power (viz. the change in $R^{2}$ from Model 2 to 3), they fail to account for the effects of class and education just as we do not find an interaction between class and exposure to international competition.

\section{Party preference}

To estimate the effects of the independent variables on party preference, we rely on 
multinomial logistic regressions. With one exception, the individual coefficients are of less interest and are, therefore, presented in the appendix. Instead, we focus mainly on the overall significance and effects of the core independent variables presented in Table 4.

Table 4. Overall significance of variables and goodness-of-fit for the multinomial logit models of party preference.

\begin{tabular}{lllll}
\hline & $\begin{array}{c}1 \\
\text { Class and } \\
\text { education }\end{array}$ & $\begin{array}{c}\text { Globalization } \\
\text { variables }\end{array}$ & $\begin{array}{c}\text { Combined } \\
\text { model }\end{array}$ & $\begin{array}{c}4 \\
\text { Interaction } \\
\text { model }\end{array}$ \\
\hline Class & $175.28 * * *$ & & $154.48^{* * *}$ & $101.70^{* * *}$ \\
Education & $116.98^{* * *}$ & & $103.08 * * *$ & $101.86^{* * *}$ \\
National ID & & $142.95 * * *$ & $117.70^{* * *}$ & $118.90^{* * *}$ \\
Offshorability & & $49.78^{* * *}$ & $23.26 * * *$ & 6.00 \\
Class x & & & & 37.28 \\
Offshorability & & & & \\
\hline McFadden's $R^{2}$ & 0.126 & 0.115 & 0.133 & 0.135 \\
AIC & 19452.507 & 19653.843 & 19326.059 & 19344.385 \\
BIC & 20216.990 & 20257.382 & 20211.250 & 20430.756 \\
\hline
\end{tabular}

Note: The Wald tests show the chi square value for the Wald test, with $p$ values in parentheses.

The short version of the results is that we replicate the pattern from the three previous tables. First, it is clear from Model 1 that both class and education affect party preference. Moving on to Model 2, we can see that the two globalization variables also have significant effects on party choice. The crucial test of $\mathrm{H} 1$ is based on Model 3, where we note that the inclusion of the globalization variables does not cause the overall effects of education and class to become insignificant. From the table we cannot see, though, whether the size of the effects of the two latter variables is affected by the inclusion of the globalization variables. We return to this matter below after observing from Model 4 that $\mathrm{H} 2$ and $\mathrm{H} 3$ have to be rejected since the interaction between class and offshorability turns out insignificant. Likewise, including the interaction does not improve the pseudo- $R^{2}$, the AIC, or the BIC. As is the case for the three attitudinal 
variables, we do not, in other words, find evidence of cross-class, globalization driven coalitions when it comes to party choice. Neither do we find evidence that people in lower classes react differently from people in higher classes when exposed to globalization.

Returning to the test of H1 we rely on the value of the so-called absolute kappa to conduct a more direct test of the mediation argument entailed in the hypothesis. The kappa index is broadly defined as the group differences in party preference (see Hout $e t$ al. 1995) and is commonly applied in studies of cleavage voting (e.g., Brooks et al. 2006; Jansen 2011; Langsæther 2017). The general definition of the absolute kappa index is

$$
\kappa_{a b s}=\sqrt{\frac{\sum_{j=1}^{J} \sum_{s=1}^{S}\left(\pi_{s}^{j}-\bar{\pi}_{s}^{j}\right)^{2}}{J * S}}
$$

where $\pi_{s}^{j}$ is the (predicted) probability that a member of social group $s$ votes for party (family) $j$. As such, the index gives a summary of the total association between a multicategorical independent variable and a multi-categorical dependent variable. We have used Lachat's (2007) cindex program to estimate the absolute kappa index for each categorical variable, as well as simulated $95 \%$ confidence intervals. The kappa values for the variables included in Model 1 and 3 appear in Figure 1.

The figure shows a very clear pattern. As can be seen by comparing, respectively, the first and third and the second and fourth bars the effects of class and education on vote choice are left substantially unchanged from Model 1 to Model 3. Thus, as is the case for (at least two of) the three attitudinal variables, the two globalization variables have significant effects on the vote (see also the fifth and sixth bars), but these effects do not detract from those of class and education. Consequently, we have to reject $\mathrm{H} 1$. 
Figure 1. Effects of the variables on party preference. Absolute kappa scores.

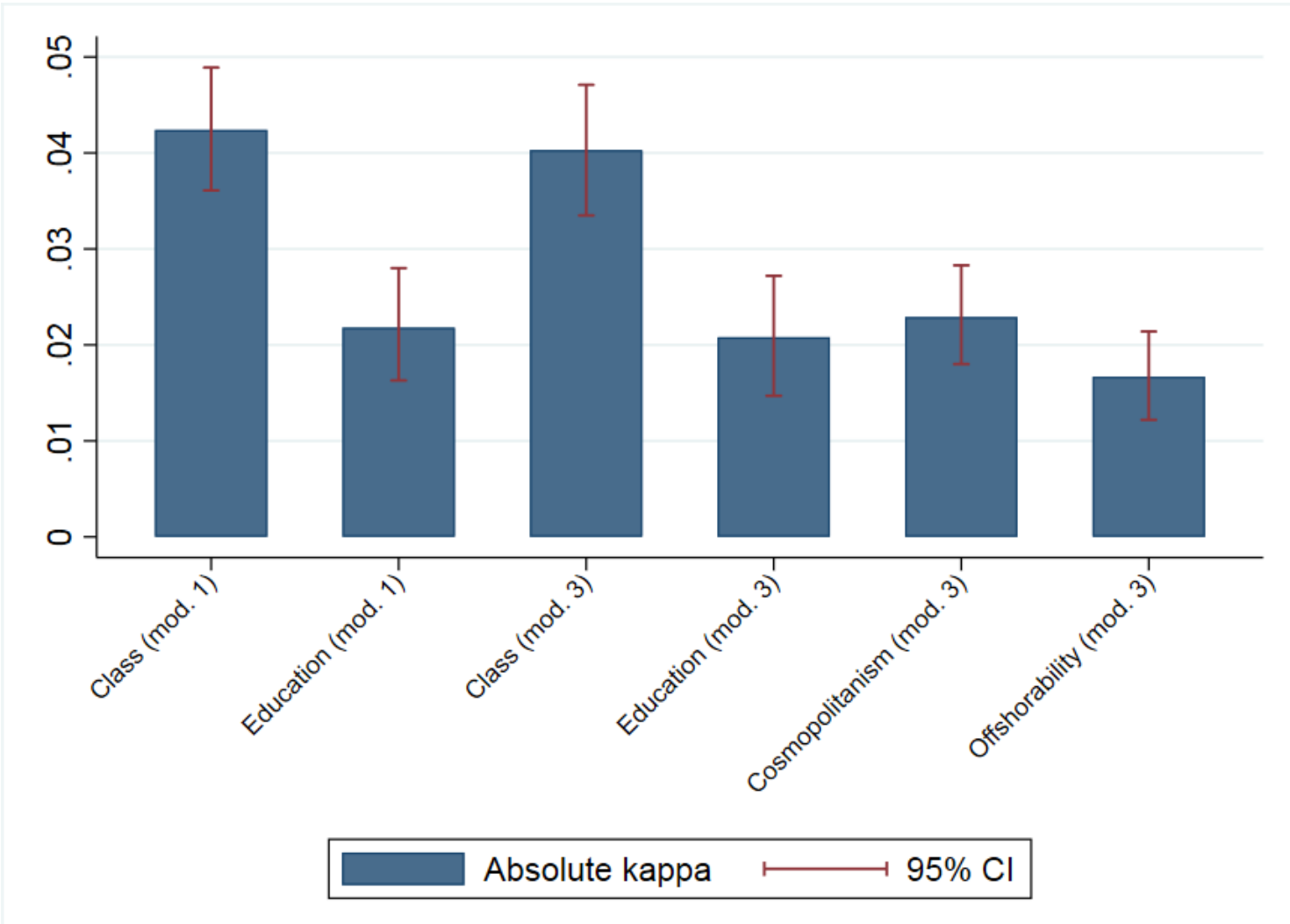

Note: The two first bars show the absolute kappa value for class and education from Model 1 . The next four bars show the kappa values for class, education, cosmopolitanism, and offshorability, calculated based on Model 3. All kappa values are shown with 95\% simulated confidence intervals. For offshorability, the calculation is based on a version of the variable with four levels of offshorability.

We should note that the conclusions with respect to party choice in general, also apply to populist right parties in particular. ${ }^{14}$ Hence, our rejection of the globalization processes as explanations for the effects of class and education also apply for the party family identified by Kriesi and co-authors as the primary choice of globalization losers. All in all, the results for party preference resemble those from the analyses of the

\footnotetext{
${ }^{14}$ The hypotheses can be evaluated based on the coefficients presented in the appendix just as a plot similar to Figure 1, but for voting for the populist right (not shown), fails to show a reduction in the effects of class and education.
} 
attitude dimensions and do not, therefore, provide the expected level of support for the implications of the globalization hypothesis. ${ }^{15}$ The effects of class and education on the vote do not, in other words, seem to reflect the globalization processes although the latter seem to have some measure of independent influence. ${ }^{16}$

\section{Conclusion and discussion}

The core claim of the globalization hypothesis advanced by Kriesi and his co-authors is that a new polarization of the 'winners' and 'losers' of globalization has taken over from older cleavages, not least over class. However, when testing this claim, the authors rely on variables tapping exactly such older cleavages, i.e. class and education. To remedy the lack of clarity with respect to the veracity of the mechanisms underlying the globalization hypothesis - degree of national (as opposed to cosmopolitan) identity, vulnerability to increased international competition, and the interaction between the latter and an individual's factor endowments - we have investigated three hypotheses about the mechanisms behind the effects of class and education on political attitudes and party preference: First, that exposure to international competition as well as individuals' degree of national versus cosmopolitan identification mediate a substantial part of the effects of class and education (H1). Second, that exposure to international competition cuts across classes leading to cross-class alliances (H2). And finally, as an

\footnotetext{
${ }^{15}$ We have opted not to conduct country level analyses of party choice simply because the individual countries - in contrast to the pooled data set used in the main analyses - do not have enough units to reliably estimate the coefficients and their standard errors given the categorical nature of both the dependent and independent variables (Menard 2002: 78-79, 93).

${ }^{16}$ We have furthermore replicated all the analyses as closely as possible with the variables available in the first two rounds of the ESS, and the results corroborate our findings here. This also holds when using other measures of globalization exposure, such as tradeability of the sector.
} 
extension of the model proposed by Kriesi et al., that exposure to globalization leads to differential political reactions from people in lower and higher classes (H3).

As the analyses above have demonstrated, the implications are not supported for any of the four, strategically selected dependent variables in our analysis: economic leftright, EU, and immigration attitudes as well as party choice. Thus, including the degree of offshorability of individuals' jobs and their degree of national identification does not reduce the effects of class and education by any noteworthy amount. Contrary to the first implication of the globalization model, hence, the effects of the two former variables are not mediated by the globalization processes. Likewise, exposure to international competition as measured by offshorability does not seem to lead to the formation of cross-class alliances of globalization winners and losers with similar attitudes and party choice nor do we see a differential reaction to globalization across classes and educational groups (except for one point discussed below). The results hold up across data sets and operationalizations, including models comprising individuals' employment sector as in the argument (but not the test) proposed by Kriesi et al.

Overall, however, although a fair amount of their impact is shared with class and education, we do find evidence for an effect of the globalization variables beyond that of the two traditional variables. Even if the variables are unable to account for the effects of class and education, this evidence might be an indicator of the existence of a globalization cleavage separate from and in addition to the traditional cleavages. Four points should, however, be noted in this context.

First, the effect of offshorability is, for all three attitudinal variables, the opposite of what the globalization model leads one to expect: those most subject to international competition, i.e. those most likely to lose from globalization, are the most economically right-wing and the most positive towards both the EU and immigration. 
Furthermore, the variable is, according to Figure 1, the one with the weakest effect on party preference - a finding that also holds for populist right parties. Second, the effect of offshorability is insignificant when controlled for class and education in Model 3 for immigration attitudes.

The cosmopolitanism/national identity variable, third, has significant effects on all four outcome variables. However, on economic attitudes, those who are more strongly identified with their country - and hence losers of globalization - have the most right-wing attitudes. This contradicts the globalization model's expectation that globalization losers should opt for protection in the form of left-wing economic policies. Nevertheless, the strength of this variable for the other three outcomes is interesting, and future research should look into whether the variable is best considered a structural or an attitudinal variable. That people who feel like they belong first and foremost to the world or to Europe are supporters of the European Union is hardly surprising. It raises, fourth, a question as to how much can be gauged about the structural roots of political alignments on the basis of this variable. ${ }^{17}$ In sum, therefore, while the two variables directly tapping into the globalization processes do show effects, these effects are often rather weak and, in many instances, run counter to expectations. We would think it appropriate, therefore, to be cautious about basing claims about a new cleavage on these variables. The same is true if we instead employ another measure of globalization exposure, namely sectoral exposure to international trade.

We should also point out that we have found no systematic country level variation in the support for our conclusions. The few differences between the results from the pooled data set and analyses in individual countries that do manifest are weak

\footnotetext{
${ }^{17}$ The same applies to our alternative operationalization of the national/cosmopolitan identification variable, cf. the appendix.
} 
and unsystematic. In addition, the globalization variables do not seem to fare better in the three Scandinavian cases in spite of the openness of their economies. We consider this problematic for the globalization model which (even if imperfectly operationalized) should be expected to have a stronger influence in countries that are highly susceptible to the influences of globalization. The same could be said in relation to the failure of the hypotheses derived from the globalization model to hold up with respect to voting for populist right parties - parties that were singled out by Kriesi and co-authors as the primary choice of the losers of globalization. Also for this critical case, hence, did the model fall short of expectations.

Across all of our models, the two traditional variables, class and education, come out as clearly significant and with fairly strong effects. As would be expected from previous research (cf. above), class is more important for economic left-right attitudes and overall party choice, education for EU and immigration attitudes. In this respect, our results do not deviate from those of Kriesi et al. who use class and education as proxies for the globalization processes. However, when placing both their and our results for these two variables alongside our tests of a set of central implications of the globalization model, the interpretation of the results would seem to be different from that offered by the globalization model. The globalization variables do not account for the effects of class and education and are, in themselves, not sufficient to sustain the claim of a new cleavage (cf. above). Rather, the purported new, globalization cleavage seems, at its core, to be a replication of the previously known conflicts over class and education.

This is not to say that the processes underlying globalization, such as increased international competition, EU-integration and migration, have no bearing on how voters behave in West European countries. Far from it, in fact. It follows straightforwardly 
from extant research on both class and education such as that reviewed above, that events like these should be expected to have political repercussions since they are likely to affect the interests and attitudes of different classes and/or educational groups in different ways, thereby creating the potential for political conflict and mobilization. Indeed, the otherwise surprising observation that individuals, particularly those with high levels of education, exposed to offshorability are more rather than less right wing on economic issues may be interpreted as indicating exactly this: that globalization processes reinvigorate classic conflicts over economic distribution. The result could reflect, thus, that those exposed to globalization in the form of international competition, the highly educated in particular, gain more from this competition than those not so exposed, i.e. the processes underlying the classic Stolper-Samuelson (1941) model (cf. also Walter 2010; 2017). Alternatively, the result could reflect that individuals with more rightist economic attitudes self-select into jobs characterized by international competition as a way to pursue the higher gains available in an internationally competitive industry; this would, incidentally, fit our observation (in Table A.1.7) that those with higher levels of education or class position are more exposed to international competition. ${ }^{18}$ Of course, these conjectures go beyond our analyses here and should be explored by future research.

In sum, our main point is not that the idea of Kriesi et al. that globalization affects political alignments is wrong - quite the contrary. What we are arguing on the basis of the analyses presented above is that the underlying conflicts are not (at least not

\footnotetext{
${ }^{18}$ For EU and immigration attitudes, the unexpected result that offshoreability is associated with more positive attitudes (although the effect is insignificant for immigration attitudes when controlling for education and class) could reflect similar self-selection and/or the effect of exposure to international impulses (cf. the contact theory of intergroup attitudes first presented by Allport 1954).
} 
primarily) centred around the mechanisms identified by Kriesi and co-authors. Rather, to a considerable degree, the conflicts revolve around the oppositions between classes and educational groups identified by previous work on these factors. We would on the basis of this, first, direct test of the mechanisms of the globalization model conclude that the proposed globalization cleavage appears rather more like old wine in new bottles. 


\section{References}

Allport, Gordon (1954). The Nature of Prejudice. Reading, MA: Addison-Wesley Publishing Co.

Atkinson, Will (2015). Class. Cambridge: Polity Press.

Blinder, Alan (2009). 'How Many U.S. Jobs Might Be Offshoreable', World Economics, 10(2), 41-78.

Braun, Michael and Walter Müller (1997). "Measurement of Education in Comparative Research", Comparative Social Research, 16(1): 163-201.

Breen, Richard, Kristian Bernt Karlson, and Anders Holm (2013). "Total, Direct, and Indirect Effects in Logit and Probit Models", Sociological Methods \& Research, 42(2): 164-191.

Brooks, Clem, Paul Nieuwbeerta, and Jeff Manza (2006). “Cleavage-based voting behavior in cross-national perspective: evidence from six postwar democracies", Social Science Research, 35(1), 88-128.

Coffé, Hilde (2013). 'Gender, class, and radical right voting', in Jens Rydgren (ed.), Class Politics and the Radical Right. New York: Routledge.

Cusack, Thomas, Torben Iversen, and Philipp Rehm (2006). 'Risks at Work: The Demand and Supply Sides of Government Redistribution', Oxford Review of Economic Policy, 22 (3), 365-389.

Dancygier, Rafaela and Stefanie Walter (2015). 'Globalization, Labor Market Risks, and Class Cleavages', in Beramendi, Pablo, Silja Häusermann, Herbert Kitschelt, and Hanspeter Kriesi (eds.), The Politics of Advanced Capitalism. Cambridge: Cambridge University Press.

Erikson, Robert, John. H. Goldthorpe, and Lucienne Portocareri (1979).

'Intergenerational class mobility in three Western European societies: England, France, and Sweden', British Journal of Sociology, 30(4), 415-441.

Erikson, Robert and John H. Goldthorpe (1992). The Constant Flux: A Study of Class Mobility in Industrial Societies. Oxford: Oxford University Press.

Evans, Geoffrey and Nan Dirk De Graaf (2013, eds.). Political Choice Matters. Explaining the Strength of the Class and Religious Cleavages in Cross-National Perspective. Oxford: Oxford University Press. 
Findlay, Ronald and Henryk Kierzkowski (1983). 'International Trade and Human Capital: A Simple General Equilibrium Model', Journal of Political Economy, $91(6), 957-978$.

Gabel, Matthew J. and Harvey D. Palmer (1995). 'Understanding Variation in Public Support for European Integration', European Journal of Political Research, 27, 3-19.

Gabel, Matthew J. (1998). 'Public Support for European Integration: An Empirical Test of Five Theories', Journal of Politics, 60(2), 333-354.

Hainmueller, Jens and Michael J. Hiscox (2006). 'Learning to Love Globalization: Education and Individual Attitudes Toward International Trade', International Organization, 60 (2), 469-498.

Hays, Jude, Sean Ehrlich, and Clint Peinhardt (2005). 'Government Spending and Public Support for Trade in the OECD: An Empirical Test of the Embedded Liberalism Thesis', International Organization, 59 (2), 473-494.

Hix, Simon (2005). 'Public Opinion', in Simon Hix (ed.), The Political System of the European Union, $2^{\text {nd }}$ edition. London: Palgrave Macmillan, 147-174.

Hout, Mike, Clem Brooks, and Jeff Manza (1995). 'The Democratic Class Struggle in the United States, 1948-1992', American Sociological Review, 60(6), 805-828.

Iversen, Torben and David Soskice (2001). 'An Asset Theory of Social Policy Preferences', American Political Science Review, 95 (4), 875-793. Jansen, Giedo (2011). Social Cleavages and Political Choices: Large-scale Comparisons of Social Class, Religion, and Voting Behaviour in Western Democracies. Nijmegen: Ipskamp Drukkers BV.

Knutsen, Oddbjørn (2017). Social Structure, Value Orientations, and Party Choice - A Comparative Study of 18 West European Countries. Palgrave Macmillan.

Knutsen, Oddbjørn and Peter Egge Langsæther (2016). Paper presented at the 24th IPSA World Congress of Political Science, Poznań, July 23 - 28.

Kriesi, Hanspeter, Edgar Grande, Martin Dolezal, Simon Bornschier, and Timothos Frey (2006). 'Globalization and the transformation of the national political space: Six European countries compared. European Journal of Political Research, 45:6, 921-956. 
Kriesi, Hanspeter, Edgar Grande, Romain Lachat, Martin Dolezal, Simon Bornschier, and Timothos Frey (2008). West European Politics in the Age of Globalization. Cambridge: Cambridge University Press.

Kriesi, Hanspeter, Edgar Grande, Martin Dolezal, Marc Helbling, Dominic Höglinger, Swen Hutter, and Bruno Wüest (2012). Political Conflict in Western Europe. Cambridge: Cambridge University Press.

Lachat, Romain (2007). "Measuring cleavage strength”. Revised version of paper prepared for delivery at the 2006 Annual Meeting of the American Political Science Association, Philadelphia, August 31-September 3.

Lipset, Seymor Martin (1981). Political Man: The Social Bases of Politics. Baltimore: John Hopkins University Press.

Lipset, Seymor Martin (1991). "No third way: a comparative perspective on the left", in Daniel Chirot (ed.). The Crisis of Leninism and the Decline of the Left. Seattle: University of Washington Press, 183-232.

Langsæther, Peter Egge (2017). 'How Religion Affects Party Preference. Mass-Party Linkages in 16 West-European Countries', paper presented at the ECPR General Conference, Oslo.

Langsæther, Peter Egge (2018). 'Class voting and the differential role of political values: Evidence from 12 West-European countries', Journal of Elections, Public Opinion, and Parties.

Menard, Scott (2002). Applied logistic regression analysis. Second edition. Thousand Oaks: Sage.

Oesch, Daniel (2006). 'Coming to Grips with a Changing Class Structure: An Analysis of Employment Stratification in Britain, Germany, Sweden, and Switzerland', International Sociology, 21(2), 263-288.

Oesch, Daniel (2008). 'Explaining Workers' Support for Right-Wing Populiar Parties in Western Europe: Evidence from Austria, Belgium, France, Norway, and Switzerland', International Political Science Review, 29, 349-373.

Oskarson, Maria and Marie Demker (2013). 'Another kind of class voting: the workingclass sympathy for Sweden Democrats', in Jens Rydgren (ed.), Class Politics and the Radical Right. New York: Routledge.

Rehm, Philipp (2009). 'Risks and Redistribution. An Individual-Level Analaysis', Comparative Political Studies, 42 (7), 855-881. 
Rommel, Tobias and Stefanie Walter (2018). "The Electoral Consequences of Offshoring: How the Globalization of Production Shapes Party Preference”, Comparative Political Studies, 51 (5), 621-658.

Scheve, Kenneth and Matthew Slaughter (2004). 'Economic Insecurity and the Globalization of Production', American Political Science Review, 48 (4), 662674.

Stolper, Wolfgang F. and Paul A. Samuelson (1941). 'Protection and real wages', The Review of Economic Studies, 9 (1), 58-73.

Stubager, Rune (2008). 'Education Effects on Authoritarian-libertarian Values: A Question of Socialization', The British Journal of Sociology, 59, 327-350.

Svallfors, Stefan (2006). The Moral Economy of Class: Class and Attitudes in Comparative Perspective. Stanford: Stanford University Press.

Vestin, Erik and Maria Oskarson (2017). "Den svenska klassröstningen på reträtt - Gör ett nytt klasschema någon skillnad?“ Politica 49 (2), 179-198.

Walter, Stefanie (2010). 'Globalization and the Welfare State: Testing the Microfoundations of the Compensation Hypothesis', International Studies Quarterly, 54 (2), 403-426.

Walter, Stefanie (2017). "Globalization and the Demand-Side of Politics: How Globalization Shapes Labor Market Risk Perceptions and Policy Preferences”, Political Science Research and Methods, 5(1), 55-80.

Walter, Stefanie and Linda Maduz (2009). 'How Globalization Shapes Individual Risk Perception and Policy Preferences. A Cross-National Analysis of Differences Between Globalization Winners and Losers', WCFIA Working Paper Series, Cambridge: Harvard University. 
Online appendix for the article Old Wine in New Bottles? Reassessing the Effects of

Globalization on Political Preferences.

\section{Contents}

A.1. Descriptive statistics

A.2. Categorization of parties into party families

A.3: The construction of the indexes

A.3.1: Economic left-right attitudes

A.3.2: EU attitudes 45

A.3.3 Immigration attitudes 46

A.4 Robustness analyses 48

A.4.1: Using another measure of national identity vs cosmopolitanism 48

A.4.2: Using a dummy version of the offshorability variable 49

A.4.3: Replications with the European Social Survey: Including a sector-based measure of globalization exposure (tradeable vs sheltered sector) 55

A.5: The country-specific analyses 65

A.5.1: Country specific analyses of economic left-right attitudes 65

A.5.2: Country specific analyses of EU attitudes 76

A.5.3: Country specific analyses of immigration attitudes 86

A.6. The multinomial logistic regression analysis of party preference 97

A.7. The full tables including all coefficients. 104 


\section{A.1. Descriptive statistics}

Table A.1.1. Descriptive statistics for continuous variables and gender.

\begin{tabular}{|l|l|l|l|l|l|}
\hline Variable & Obs. & Mean & Std. Dev. & Min & Max \\
\hline $\begin{array}{l}\text { Economic } \\
\text { left-right } \\
\text { attitudes }\end{array}$ & 8,085 & 4.20 & 1.62 & 0 & 10 \\
\hline EU attitudes & 6,936 & 5.58 & 2.59 & 0 & 10 \\
\hline $\begin{array}{l}\text { Immigration } \\
\text { attitudes }\end{array}$ & 8,085 & 4.61 & 2.16 & 0 & 10 \\
\hline Offshorability & 8,085 & 2.45 & 3.13 & 0 & 10 \\
\hline Age & 8,085 & 49.80 & 16.63 & 15 & 108 \\
\hline Urban-rural & 8,085 & 3.54 & 2.27 & 0 & 7 \\
\hline Female & 8,085 & 0.52 & 0.50 & 0 & 1 \\
\hline
\end{tabular}

Table A.1.2. Party preference

\begin{tabular}{|l|l|l|}
\hline Party family & $\#$ & $\%$ \\
\hline Comm./Left socialist & 633 & 10.48 \\
\hline Green/New Left & 518 & 8.58 \\
\hline Soc. Dem. & 1,486 & 24.60 \\
\hline Liberal & 771 & 12.76 \\
\hline Christ.Dem./Conservative & 1,639 & 27.14 \\
\hline Populist Right & 475 & 7.86 \\
\hline Other & 518 & 8.58 \\
\hline Total & 6,040 & 100.00 \\
\hline
\end{tabular}

Table A.1.3. National identity versus cosmopolitanism (variable used in main analyses, based on questions of sense of belonging).

\begin{tabular}{|l|l|l|}
\hline National identity & $\#$ & \% \\
\hline Strong national identity & 5,397 & 66.75 \\
\hline Intermediate & 1,528 & 18.90 \\
\hline Cosmopolitan & 1,160 & 14.35 \\
\hline Total & 8,085 & 100.00 \\
\hline
\end{tabular}

Table A.1.4. National identity versus cosmopolitanism - measured by question of pride over citizenship (used in robustness check, not in main analyses).

National identity $\#$ $\%$ 


\begin{tabular}{|l|l|l|}
\hline Strong national identity & 3,019 & 40.68 \\
\hline Medium national identity & 3,522 & 47.45 \\
\hline Weak national identity & 881 & 11.87 \\
\hline Total & 7,422 & 100.00 \\
\hline
\end{tabular}

Table A.1.5. Education.

\begin{tabular}{|l|l|l|}
\hline Education & $\#$ & $\%$ \\
\hline Low education & 1,874 & 23.18 \\
\hline Medium education & 3,648 & 45.12 \\
\hline Higher education & 2,563 & 31.70 \\
\hline Total & 8,085 & 100.00 \\
\hline
\end{tabular}

Table A.1.6. EGP class.

\begin{tabular}{|l|l|l|}
\hline EGP Class & $\#$ & \% \\
\hline Higher service class & 1,419 & 17.55 \\
\hline Lower service class & 2,199 & 27.20 \\
\hline Routine non-manual & 1,907 & 23.59 \\
\hline Petite bourgeoisie & 524 & 6.48 \\
\hline Skilled worker & 915 & 11.32 \\
\hline Unskilled worker & 1,121 & 13.87 \\
\hline Total & 8,085 & 100.00 \\
\hline
\end{tabular}

Table A.1.7. The relationship between offshorability, cosmopolitanism and the other independent variables.

\begin{tabular}{|l|l|l|l|l|}
\hline Class & $\begin{array}{l}\text { Offshorability } \\
\text { (mean value) }\end{array}$ & $\begin{array}{l}\text { \% } \\
\text { strong } \\
\text { national } \\
\text { id }\end{array}$ & $\begin{array}{l}\text { \% } \\
\text { intermediate }\end{array}$ & $\begin{array}{l}\text { \% } \\
\text { cosmopolitans }\end{array}$ \\
\hline Higher service class & 2.9 & 57.6 & 26.5 & 15.9 \\
\hline Lower service class & 3.1 & 61.9 & 21.6 & 16.5 \\
\hline $\begin{array}{l}\text { Routine non-manual } \\
\text { employees }\end{array}$ & 2.2 & 70.5 & 15.5 & 14.0 \\
\hline Petite bourgeoisie & 3.2 & 74.1 & 15.8 & 10.1 \\
\hline Skilled workers & 1.9 & 72.9 & 14.9 & 12.2 \\
\hline Unskilled workers & 1.1 & 73.2 & 14.5 & 12.3 \\
\hline & \multicolumn{5}{|l}{} \\
\hline Education & \multicolumn{5}{|l}{} \\
\hline Higher education & 2.7 & 57.6 & 24.0 & 18.4 \\
\hline Medium education & 2.5 & 69.9 & 16.6 & 13.5 \\
\hline Lower education & 2.1 & 72.3 & 16.4 & 10.3 \\
\hline
\end{tabular}




\begin{tabular}{|c|c|c|c|c|}
\hline \multicolumn{5}{|l|}{ Cosmopolitanism } \\
\hline $\begin{array}{l}\text { Strong national } \\
\text { identity }\end{array}$ & 2.4 & & & \\
\hline Intermediate & 2.5 & & & \\
\hline Cosmopolitan & 2.6 & & & \\
\hline \multicolumn{5}{|l|}{ Sex } \\
\hline Male & 2.6 & 64.7 & 20.1 & 15.1 \\
\hline Female & 2.3 & 68.6 & 17.7 & 13.6 \\
\hline Age (pearson's r) & 0.02 & & & \\
\hline $\begin{array}{l}\text { Urban-rural } \\
\text { residence } \\
\text { (pearson's r) }\end{array}$ & 0.05 & & & \\
\hline
\end{tabular}

The table shows that there are only small differences with respect to offshoreability between the educational groups: On average, those with higher education are at 2.7 on the scale from 0-10, while those with lower education are at 2.1 , with medium educated people in the middle at 2.5. In other words, those with higher education tend to have slightly more offshorable jobs. Likewise, there are only moderate differences across classes. The most offshorable occupations are found among the petite bourgeoisie (3.2), the lower service class (3.1) and the higher service class (2.9). The least offshorable occupations are found among the skilled (1.9) and unskilled (1.1) workers with routine non-manual employees occupying a middle position at 2.2.

Class is also only moderately associated with cosmopolitanism. While $16.5 \%$ of the lower service class are cosmopolitans, the same is true for only $10.1 \%$ of the petite bourgeoisie, with the other classes in between. The relationship is somewhat stronger for education: $18.4 \%$ of those with higher education are cosmopolitans, while for those with lower education the share of cosmopolitans is only $10.3 \%$. 
A.2. Categorization of parties into party families

\begin{tabular}{|c|c|c|c|c|c|c|}
\hline & $\begin{array}{l}\text { Communi } \\
\text { sts / } \\
\text { Radical } \\
\text { Left }\end{array}$ & $\begin{array}{l}\text { Greens/ } \\
\text { New Left }\end{array}$ & $\begin{array}{l}\text { Social } \\
\text { Democrats }\end{array}$ & Liberals & $\begin{array}{l}\text { Christian } \\
\text { Democrats / } \\
\text { Conservatives }\end{array}$ & $\begin{array}{l}\text { Populist } \\
\text { Right }\end{array}$ \\
\hline Austria & $\begin{array}{l}\text { Kommunist } \\
\text { ische } \\
\text { Partei } \\
\text { Österreich } \\
s\end{array}$ & $\begin{array}{l}\text { Die } \\
\text { Grünen/Di } \\
\text { e Grüne } \\
\text { Alternative }\end{array}$ & $\begin{array}{l}\text { Sozialdemokr } \\
\text { atische Partei } \\
\text { Österreichs } \\
(\text { SPÖ) }\end{array}$ & $\begin{array}{l}\text { Liberales } \\
\text { Forum } \\
(\text { LIF })\end{array}$ & $\begin{array}{l}\text { Österreichische } \\
\text { Volkspartei } \\
(\ddot{O} V P)\end{array}$ & $\begin{array}{l}\text { Freiheitlich } \\
\text { e Partei } \\
\text { Österreich } \\
(\text { FPÖ) }\end{array}$ \\
\hline $\begin{array}{l}\text { Denmar } \\
\mathrm{k}\end{array}$ & $\begin{array}{l}\text { Socialistisk } \\
\text { Folkeparti } \\
(S F) \text {, } \\
\text { Enhedslist } \\
\text { en - De } \\
\text { Rødgrønne } \\
(E L)\end{array}$ & & $\begin{array}{l}\text { Socialdemokr } \\
\text { atiet } i \\
\text { Danmark }(S)\end{array}$ & $\begin{array}{l}\text { Det } \\
\text { Radikale } \\
\text { Venstre } \\
(R V)\end{array}$ & $\begin{array}{l}\text { Venstre, } \\
\text { Danmarks } \\
\text { Liberale Parti } \\
(\text { V), Det } \\
\text { Konservative } \\
\text { Folkeparti (KF), } \\
\text { Kristendemokrat } \\
\text { erne (KD) }\end{array}$ & $\begin{array}{l}\text { Dansk } \\
\text { Folkeparti }\end{array}$ \\
\hline France & $\begin{array}{l}\text { Parti } \\
\text { Communist } \\
\text { e Français } \\
(P C F) \text { and } \\
\text { Trotskyist } \\
\text { parties }\end{array}$ & $\begin{array}{l}\text { Les Verts, } \\
\text { other } \\
\text { environme } \\
\text { ntalist } \\
\text { parties }\end{array}$ & $\begin{array}{l}\text { Parti } \\
\text { Socialiste } \\
(P S)\end{array}$ & $\begin{array}{l}\text { Union } \\
\text { pour la } \\
\text { Démocrati } \\
e \\
\text { Française } \\
(U D F) / M \\
\text { oDem }\end{array}$ & $\begin{array}{l}\text { Union Pour un } \\
\text { Mouvement } \\
\text { Populaire } \\
(U M P)\end{array}$ & $\begin{array}{l}\text { Front } \\
\text { National } \\
(\text { FN })\end{array}$ \\
\hline $\begin{array}{l}\text { German } \\
\mathrm{y}\end{array}$ & $\begin{array}{l}\text { Partei des } \\
\text { Demokrati } \\
\text { schen } \\
\text { Sozialismu } \\
\text { s }(P D S) \\
\end{array}$ & $\begin{array}{l}\text { Bündnis } \\
\text { 90/Die } \\
\text { Grünen }\end{array}$ & $\begin{array}{l}\text { Sozialdemokr } \\
\text { atische Partei } \\
\text { Deutschlands } \\
\text { (SPD) }\end{array}$ & $\begin{array}{l}\text { Freie } \\
\text { Demokrati } \\
\text { sche } \\
\text { Partei } \\
(\text { FDP })\end{array}$ & $\begin{array}{l}\text { Christlich- } \\
\text { Demokratische } \\
\text { Union/Christlich } \\
\text {-Soziale Union } \\
\text { (CDU/CSU) }\end{array}$ & - \\
\hline $\begin{array}{l}\text { Netherl } \\
\text { ands }\end{array}$ & $\begin{array}{l}\text { Socialistisc } \\
\text { he Partij } \\
(S P)\end{array}$ & $\begin{array}{l}\text { GroenLink } \\
s(G L)\end{array}$ & $\begin{array}{l}\text { Partij van de } \\
\text { Arbeid } \\
(P v d A)\end{array}$ & $\begin{array}{l}\text { Democrat } \\
\text { en '66 } \\
\text { (D66); } \\
\text { Volksparti } \\
\text { j voor } \\
\text { Vrijheid } \\
\text { en } \\
\text { Democrati } \\
\text { e(VVD) }\end{array}$ & $\begin{array}{l}\text { Christen- } \\
\text { Demokratisch } \\
\text { Appel (CDA) }\end{array}$ & $\begin{array}{l}\text { Partij voor } \\
\text { de Vrijheid } \\
(P V V)\end{array}$ \\
\hline Norway & $\begin{array}{l}\text { Rødt }(R), \\
\text { Sosialistisk } \\
\text { Venstrepar } \\
t i(S V)\end{array}$ & - & $\begin{array}{l}\text { Arbeiderparti } \\
\text { et }(A p)\end{array}$ & $\begin{array}{l}\text { Venstre } \\
(V)\end{array}$ & $\begin{array}{l}\text { Hoyre }(H), \\
\text { Kristelig } \\
\text { Folkeparti }(\mathrm{KrF})\end{array}$ & $\begin{array}{l}\text { Fremskritts } \\
\text { partiet } \\
(\mathrm{FrP})\end{array}$ \\
\hline Sweden & $\begin{array}{l}\text { Vänstern } \\
(V)\end{array}$ & $\begin{array}{l}\text { Miljöpartie } \\
\text { t de Gröna } \\
(M P)\end{array}$ & $\begin{array}{l}\text { Socialdemokr } \\
\text { atiske } \\
\text { arbetareparti } \\
\text { et }(S A P)\end{array}$ & $\begin{array}{l}\text { Folkpartie } \\
t \\
\text { Liberalern } \\
a(F P)\end{array}$ & $\begin{array}{l}\text { Moderaterna } \\
(M), \\
\text { Kristdemokrater } \\
\text { na }(K D)\end{array}$ & - \\
\hline
\end{tabular}




\begin{tabular}{|c|c|c|c|c|c|c|}
\hline $\begin{array}{l}\text { Switzerl } \\
\text { and }\end{array}$ & $\begin{array}{l}\text { Partei der } \\
\text { Arbeit der } \\
\text { Schweiz } \\
(\text { PdA })\end{array}$ & $\begin{array}{l}\text { Grüne } \\
\text { Partei der } \\
\text { Schweiz } \\
\text { (GPS), } \\
\text { Grünlibera } \\
\text { le Partei } \\
\text { der } \\
\text { Schweiz } \\
(\text { GlP) }\end{array}$ & $\begin{array}{l}\text { Sozialdemokr } \\
\text { atische Partei } \\
\text { der Schweiz } \\
(S P S)\end{array}$ & $\begin{array}{l}\text { Freisinnig } \\
- \\
\text { Demokrati } \\
\text { sche } \\
\text { Partei } \\
(\text { FDP }) ; \\
\text { Liberale } \\
\text { Partei der } \\
\text { Schweiz } \\
(\text { LPS })\end{array}$ & $\begin{array}{l}\text { Christlichdemok } \\
\text { ratische } \\
\text { Volkspartei der } \\
\text { Schewiz }(C V P)\end{array}$ & $\begin{array}{l}\text { Schweizeris } \\
\text { che } \\
\text { Volkspartei } \\
(S V P)\end{array}$ \\
\hline UK & & $\begin{array}{l}\text { Green } \\
\text { Party } \\
\text { (GRN) }\end{array}$ & Labour party & $\begin{array}{l}\text { Liberal } \\
\text { Democrati } \\
\text { c party }\end{array}$ & $\begin{array}{l}\text { Conservative } \\
\text { party }\end{array}$ & \\
\hline & & & & & & \\
\hline
\end{tabular}

Some parties could not be classified according to any of the six party families, and were classified as "others". These are listed below.

Austria: Bündnis Zukunft Österreich (BZÖ), Liste Dr. Hans-Peter Martin.

Denmark: -

France: Nouveau Centre; Chasse, pêche, nature et traditions; Mouvement pour la

France.

Germany: Die Republikaner (REP), Nationaldemocratische Partei Deutschlands (NPD), Deutsche Volksunion (DVU)

Netherlands: ChristenUnie (CU), Staatkundig Gereformeerde Partij (SGP), Partij voor de Dieren (PvdD), Trots op Nederland (TON)

Norway: Senterpartiet $(\mathrm{Sp})$.

Sweden: -

Switzerland: Schweizer Demokraten (SD/DS), Eidgenössisch-Demokratische Union (EDU), Evangelische Volkspartei der Schweiz (EVP), Liga der Tessiner.

UK: Plaid Cymry (PC), Scottish National Party (SNP).

A.3: The construction of the indexes

\section{A.3.1: Economic left-right attitudes}

The economic left-right value index is based on the work of Oddbjørn Knutsen (2017).

The index is based on the following variables in the dataset and the question number in the questionnaire: 
V194 (Q58A): Individual/state responsibility

V197 (Q58D): Economic freedom/control

V198 (Q58E): Income equality/incentives

V199 (Q58F): Private/public ownership

V196 (Q58C): Competition good/harmful

The variables were tapped by a question battery where the respondents were shown a card with two opposite statements located to the endpoints of a scale from 1 to 10 . The question was formulated as follows: "On this card you see a number of opposite views on various issues. How would you place your views on this scale?"

V194 (Q58A): Individual/state responsibility

"Individuals should take more responsibility for providing for themselves" versus "The state should take more responsibility to ensure that everyone is provided for".

V197 (Q58D): Economic freedom/control

"The state should give more freedom to firms" versus "The state should control firms more effectively".

V198 (Q58E): Income equality/incentives

"Incomes should be made more equal" versus "There should be greater incentives for individual effort".

V199 (Q58F): Private/public ownership

"Private ownership of business and industry should be increased" versus "government ownership of business and industry should be increased".

V196 (Q58C): Competition good/harmful

"Competition is good. It stimulates people to work hard and develop new ideas" versus "Competition is harmful, it brings out the worst in people"

Table A.3.1: Cronbach's $\alpha$ for the economic left-right values index in the pooled data and the individual countries

\begin{tabular}{|l|l|}
\hline & Cronbach's $\alpha$ \\
\hline Pooled & 0.6235 \\
\hline
\end{tabular}




\begin{tabular}{|l|l|}
\hline Austria & 0.5589 \\
\hline France & 0.5649 \\
\hline Germany & 0.5809 \\
\hline Netherlands & 0.6043 \\
\hline Switzerland & 0.6333 \\
\hline UK & 0.6332 \\
\hline Denmark & 0.6999 \\
\hline Norway & 0.7207 \\
\hline Sweden & 0.7775 \\
\hline
\end{tabular}

\section{A.3.2: EU attitudes}

We constructed the EU orientations index based on Q73: "Some people may have fears about the building of the European Union. I am going to read a number of things which people say they are afraid of. For each tell me if you - personally - are currently afraid of." The respondent may then indicate on a scale from 1-10 how much they fear the following five aspects of EU membership, where 1 indicates the respondent being very much afraid and 10 is not afraid at all:

V257: "The loss of social security"

V258: "The loss of national identity and culture"

V259: "Our country paying more and more to the European Union"

V260: "A loss of power in the world for [COUNTRY]"

V261: "The loss of jobs in [COUNTRY]"

To create the index, we first turned the scales and substracted one, so that the value 0 on a question indicates that they are not at all afraid, while the value 9 indicates that they are very much afraid. We then added the responses together for each of the five questions and divided them by five. Finally, we divided the index by 9 and multiplied it with 10 to make it go from $0-10$ like the other indexes. 
The Cronbach's alpha for the EU index in the pooled data and in each individual country are shown below and indicate very good reliability. As mentioned in the article, the question is not asked in Norway as Norway is not a member of the EU.

Table A.3.2: Cronbach's $\alpha$ for the EU index in the pooled data and the individual countries

\begin{tabular}{|l|l|}
\hline & Cronbach's $\alpha$ \\
\hline Pooled & 0.8681 \\
\hline Austria & 0.8636 \\
\hline France & 0.8527 \\
\hline Germany & 0.8258 \\
\hline Netherlands & 0.8308 \\
\hline Switzerland & 0.8797 \\
\hline UK & 0.8719 \\
\hline Denmark & 0.8619 \\
\hline Norway & - \\
\hline Sweden & 0.8929 \\
\hline
\end{tabular}

\section{A.3.3 Immigration attitudes}

The immigration index is based on the work of Oddbjørn Knutsen (2017). These orientations are tapped by six questions which are asked in a battery where the respondents were shown a card with two opposite statements located at the endpoints of a scale from 1 to 10 . The questions were formulated as follows:

Q78: "Please look at the following statements and indicate where you would place your views on this scale? (from 1 to 10 ) “

A (V268): Take jobs

"Immigrants take jobs away from natives in a country" versus "immigrants do not take jobs away from natives in a country" 
B (V269): Cultural life undermined

"A country's cultural life is undermined by immigrants" versus "a country's cultural life is not undermined by immigrants"

C (V270): Crime problems

"Immigrants make crime problems worse" versus "immigrants do not make crime problems worse"

D (V271): Welfare

"Immigrants are a strain on a country's welfare system" versus "immigrants are not a strain on a country's welfare system"

E (V272): Threat to society

"In the future the proportion of immigrants will become a threat to society" versus "in the future the proportion of immigrants will not become a threat to society"

F (V273): Customs and traditions

"For the greater good of society it is better if immigrants maintain their distinct customs and traditions" versus "for the greater good of society it is better if immigrants do not maintain their distinct customs and traditions, but adopt the customs of the country"

An equal-weighted additive index was constructed on the basis of these six items. The index has values from 0 to 10 , and a high score indicates a non-restrictive view on immigration and a positive view on immigrants.

The Cronbach's $\alpha$ for the immigration index in the pooled data and in the individual countries are listed in table A.3.3.

Table A.3.3: Cronbach's $\alpha$ for the immigration index in the pooled data and the individual countries

\begin{tabular}{|l|l|}
\hline & Cronbach's $\alpha$ \\
\hline Pooled & 0.8281 \\
\hline Austria & 0.8371 \\
\hline France & 0.8388 \\
\hline Germany & 0.7889 \\
\hline
\end{tabular}




\begin{tabular}{|l|l|}
\hline Netherlands & 0.8203 \\
\hline Switzerland & 0.8286 \\
\hline UK & 0.8512 \\
\hline Denmark & 0.8130 \\
\hline Norway & 0.7901 \\
\hline Sweden & 0.8895 \\
\hline
\end{tabular}

\section{A.4 Robustness analyses}

\section{A.4.1: Using another measure of national identity vs cosmopolitanism}

One could argue that the variable using sense of belonging is not an ideal measure of national identity. In part, it sets the bar very high for being cosmopolitan. The EVS contains another variable that could also be used to tap sense of national identity, namely a question of "how proud are you to be a [country] citizen?". Those who responded "very proud" are coded as having a strong national identity. Those who responded "quite proud" are considered to have a medium national identity. Those who responded "not very proud" or "not at all proud" are coded as having a weak national identity. Descriptive statistics for this variable is available above.

In table A.4.1, we list the results of the globalization model from the main analyses in the article's model 2 where we used the old variable related to geographic sense of belonging (A) and compare it to the same analyses using the new "pride" variable (B). Briefly stated, the effects are always in the same direction and of relatively similar strength, although the new variable is marginally better at predicting economic left-right attitudes, while the old variable is a bit better at predicting EU and immigration attitudes. None of this changes any of the substantial conclusions in the article.

Table A.4.1: Robustness analysis using different measure of national identity

\begin{tabular}{|c|c|c|c|c|c|c|}
\hline & $\begin{array}{l}\text { (1a) } \\
\text { ECLR }\end{array}$ & $\begin{array}{l}\text { (1b) } \\
\text { ECLR }\end{array}$ & $\begin{array}{l}(2 a) \\
E U\end{array}$ & $\begin{array}{l}(2 b) \\
E U\end{array}$ & $\begin{array}{c}(3 a) \\
\text { Immigration }\end{array}$ & $\begin{array}{c}(3 \mathrm{~b}) \\
\text { Immigration }\end{array}$ \\
\hline A: Intermediate & $\begin{array}{c}0.01 \\
(0.05)\end{array}$ & & $\begin{array}{c}-0.95^{* * *} \\
(0.08)\end{array}$ & & $\begin{array}{c}0.79^{* * *} \\
(0.06)\end{array}$ & \\
\hline A: Cosmopolitan & $\begin{array}{l}0.22^{* * * *} \\
(0.06)\end{array}$ & & $\begin{array}{c}-1.57^{* * *} \\
(0.09)\end{array}$ & & $\begin{array}{l}1.45^{* * *} \\
(0.07)\end{array}$ & \\
\hline B: Medium nat. id. & & $\begin{array}{l}0.24^{* * *} \\
(0.04)\end{array}$ & & $\begin{array}{c}-0.49^{* * *} \\
(0.07)\end{array}$ & & $\begin{array}{l}0.55^{\text {*** }} \\
(0.05)\end{array}$ \\
\hline B: Weak nat. id. & & $\begin{array}{l}0.56^{* * *} \\
(0.07)\end{array}$ & & $\begin{array}{c}-0.97^{* * *} \\
(0.11)\end{array}$ & & $\begin{array}{l}1.13^{* * *} \\
(0.09)\end{array}$ \\
\hline
\end{tabular}




\begin{tabular}{|c|c|c|c|c|c|c|}
\hline Offshorability & $\begin{array}{c}-0.04^{* * *} \\
(0.01)\end{array}$ & $\begin{array}{c}-0.04^{* * *} \\
(0.01)\end{array}$ & $\begin{array}{c}-0.05^{* * *} \\
(0.01)\end{array}$ & $\begin{array}{c}-0.05^{* * *} \\
(0.01)\end{array}$ & $\begin{array}{c}0.03^{* * *} \\
(0.01)\end{array}$ & $\begin{array}{c}0.03^{* * * *} \\
(0.01)\end{array}$ \\
\hline Female & $\begin{array}{c}0.40^{* * *} \\
(0.04)\end{array}$ & $\begin{array}{l}0.41^{* * *} \\
(0.04)\end{array}$ & $\begin{array}{c}0.32^{* * *} \\
(0.06)\end{array}$ & $\begin{array}{c}0.43^{* * *} \\
(0.06)\end{array}$ & $\begin{array}{l}0.24^{* * *} \\
(0.05)\end{array}$ & $\begin{array}{c}0.19^{* * * *} \\
(0.05)\end{array}$ \\
\hline Age & $\begin{array}{l}-0.00 \\
(0.00)\end{array}$ & $\begin{array}{l}-0.00 \\
(0.00)\end{array}$ & $\begin{array}{c}0.00 \\
(0.00)\end{array}$ & $\begin{array}{c}0.00 \\
(0.00)\end{array}$ & $\begin{array}{c}-0.01^{* * *} \\
(0.00)\end{array}$ & $\begin{array}{c}-0.01^{* * * *} \\
(0.00)\end{array}$ \\
\hline Urban-rural & $\begin{array}{l}0.03^{\text {** }} \\
(0.01)\end{array}$ & $\begin{array}{l}0.02^{*} \\
(0.01)\end{array}$ & $\begin{array}{c}-0.07^{* * *} \\
(0.01)\end{array}$ & $\begin{array}{c}-0.09^{* * *} \\
(0.01)\end{array}$ & $\begin{array}{c}0.08^{* * *} \\
(0.01)\end{array}$ & $\begin{array}{c}0.09^{* * * *} \\
(0.01)\end{array}$ \\
\hline Constant & $\begin{array}{c}4.33^{* * *} \\
(0.08)\end{array}$ & $\begin{array}{c}4.18^{* * *} \\
(0.09)\end{array}$ & $\begin{array}{c}6.32^{* * *} \\
(0.14)\end{array}$ & $\begin{array}{c}6.29^{* * *} \\
(0.15)\end{array}$ & $\begin{array}{c}3.57^{* * *} \\
(0.11)\end{array}$ & $\begin{array}{c}3.42^{* * * *} \\
(0.12) \\
\end{array}$ \\
\hline Observations & 8084 & 7421 & 6935 & 6407 & 8084 & 7421 \\
\hline$R^{2}$ & 0.054 & 0.064 & 0.127 & 0.090 & 0.151 & 0.125 \\
\hline Adjusted $R^{2}$ & 0.052 & 0.063 & 0.126 & 0.088 & 0.150 & 0.123 \\
\hline
\end{tabular}

\section{A.4.2: Using a dummy version of the offshorability variable}

In this section, we replicate all the pooled analyses from the article for the four dependent variables. While model 1 is identical to the ones in the article, model 2-4 now include a dichotomous measure of offshorability instead of the continuous one: Either the respondent works in an offshorable occupation, or he/she does not. To sum up, the results are identical to those in the article for EU attitudes and immigration attitudes. For economic left-right attitudes and party choice, there is some evidence in favour of a statistically significant, but substantially irrelevant, interaction effect between class and dichotomous offshorability.

Table A.4.2.1 shows the results for economic left-right attitudes. Model 2 shows, like in the article, a weak association between offshorability and economic left-right attitudes, which is further weakened in the combined model 3. Model 4 adds the interaction effect. As is clear, only one of the interaction terms is statistically significant, indicating that people in the lower service class are slightly more right-wing when they work in 
offshorable occupations. The effect is weak and the $\mathrm{R}^{2}$ only increases by 0.002

compared to model 4 (despite introducing a number of new coefficients), indicating that the interaction terms do not add anything of substantial importance to the model.

Table A.4.2.1: Explaining Economic Left-Right Attitudes. OLS. Dummy offshorable variable.

\begin{tabular}{|c|c|c|c|c|}
\hline & $\begin{array}{c}1 \\
\text { Class and } \\
\text { education }\end{array}$ & $\begin{array}{c}2 \\
\text { Globalization } \\
\text { variables }\end{array}$ & $\begin{array}{c}3 \\
\text { Combined } \\
\text { model }\end{array}$ & $\begin{array}{c}4 \\
\text { Interaction } \\
\text { model }\end{array}$ \\
\hline Hi. serv. & $\begin{array}{c}-0.78^{* * *} \\
(0.07)\end{array}$ & & $\begin{array}{c}-0.73^{* * * *} \\
(0.07)\end{array}$ & $\begin{array}{c}-0.65^{* * *} \\
(0.09)\end{array}$ \\
\hline Lo. serv. & $\begin{array}{c}-0.44^{* * *} \\
(0.07)\end{array}$ & & $\begin{array}{c}-0.38^{* * *} \\
(0.07)\end{array}$ & $\begin{array}{c}-0.23^{* *} \\
(0.08)\end{array}$ \\
\hline Rout.nman & $\begin{array}{c}-0.19^{* *} \\
(0.06)\end{array}$ & & $\begin{array}{l}-0.16^{*} \\
(0.06)\end{array}$ & $\begin{array}{l}-0.11 \\
(0.07)\end{array}$ \\
\hline Petite b. & $\begin{array}{c}-0.99^{* * *} \\
(0.09)\end{array}$ & & $\begin{array}{c}-0.92^{* * *} \\
(0.09)\end{array}$ & $\begin{array}{c}-0.88^{* * *} \\
(0.13)\end{array}$ \\
\hline Skilled w. & $\begin{array}{l}-0.06 \\
(0.07)\end{array}$ & & $\begin{array}{l}-0.04 \\
(0.07)\end{array}$ & $\begin{array}{l}-0.10 \\
(0.08)\end{array}$ \\
\hline Medium edu & $\begin{array}{c}-0.18^{* * *} \\
(0.05)\end{array}$ & & $\begin{array}{l}-0.17^{* *} \\
(0.05)\end{array}$ & $\begin{array}{c}-0.17^{* *} \\
(0.05)\end{array}$ \\
\hline Higher edu & $\begin{array}{l}-0.13^{*} \\
(0.06)\end{array}$ & & $\begin{array}{l}-0.15^{* *} \\
(0.06)\end{array}$ & $\begin{array}{c}-0.16^{* *} \\
(0.06)\end{array}$ \\
\hline Intermediate & & $\begin{array}{c}0.00 \\
(0.05)\end{array}$ & $\begin{array}{c}0.06 \\
(0.05)\end{array}$ & $\begin{array}{c}0.06 \\
(0.05)\end{array}$ \\
\hline Cosmopolitan & & $\begin{array}{c}0.22^{* * *} \\
(0.06)\end{array}$ & $\begin{array}{c}0.25^{* * *} \\
(0.06)\end{array}$ & $\begin{array}{l}0.26^{* * *} \\
(0.06)\end{array}$ \\
\hline $\begin{array}{l}\text { Offshoreable } \\
\text { (dummy) }\end{array}$ & & $\begin{array}{c}-0.29^{* * *} \\
(0.04)\end{array}$ & $\begin{array}{c}-0.18^{* * *} \\
(0.04)\end{array}$ & $\begin{array}{c}0.03 \\
(0.12)\end{array}$ \\
\hline $\begin{array}{l}\text { Hi. serv. \# } \\
\text { offshoreable }\end{array}$ & & & & $\begin{array}{l}-0.26 \\
(0.15)\end{array}$ \\
\hline $\begin{array}{l}\text { Lo. serv. \# } \\
\text { offshoreable }\end{array}$ & & & & $\begin{array}{l}-0.38^{* *} \\
(0.14)\end{array}$ \\
\hline $\begin{array}{l}\text { Rout.nman \# } \\
\text { offshoreable }\end{array}$ & & & & $\begin{array}{l}-0.20 \\
(0.14)\end{array}$ \\
\hline $\begin{array}{l}\text { Petite b. \# } \\
\text { offshoreable }\end{array}$ & & & & $\begin{array}{l}-0.19 \\
(0.20)\end{array}$ \\
\hline
\end{tabular}


Skilled w. \#
offshoreable

\begin{tabular}{|c|c|c|c|c|}
\hline Female & $\begin{array}{c}0.34^{* * *} \\
(0.04)\end{array}$ & $\begin{array}{c}0.39^{* * *} \\
(0.04)\end{array}$ & $\begin{array}{c}0.34^{* * *} \\
(0.04)\end{array}$ & $\begin{array}{c}0.32^{\text {**** }} \\
(0.04)\end{array}$ \\
\hline Age & $\begin{array}{l}-0.00 \\
(0.00)\end{array}$ & $\begin{array}{l}-0.00 \\
(0.00)\end{array}$ & $\begin{array}{l}-0.00 \\
(0.00)\end{array}$ & $\begin{array}{l}-0.00 \\
(0.00)\end{array}$ \\
\hline Urban-rural & $\begin{array}{c}0.04^{* * * *} \\
(0.01)\end{array}$ & $\begin{array}{l}0.03^{\text {** }} \\
(0.01)\end{array}$ & $\begin{array}{c}0.03^{* * *} \\
(0.01)\end{array}$ & $\begin{array}{c}0.03^{\text {**** }} \\
(0.01)\end{array}$ \\
\hline Constant & $\begin{array}{c}4.76^{* * * *} \\
(0.11) \\
\end{array}$ & $\begin{array}{c}4.35^{* * *} \\
(0.08) \\
\end{array}$ & $\begin{array}{c}4.71^{* * *} \\
(0.11) \\
\end{array}$ & $\begin{array}{c}4.68^{* * * *} \\
(0.11) \\
\end{array}$ \\
\hline $\begin{array}{l}\text { Observations } \\
R^{2} \\
\text { Adjusted } R^{2}\end{array}$ & $\begin{array}{l}8084 \\
0.084 \\
0.082\end{array}$ & $\begin{array}{l}8084 \\
0.056 \\
0.055\end{array}$ & $\begin{array}{l}8084 \\
0.090 \\
0.087\end{array}$ & $\begin{array}{l}8084 \\
0.092 \\
0.089\end{array}$ \\
\hline
\end{tabular}

Standard errors in parentheses

${ }^{*} p<0.05,{ }^{* *} p<0.01,{ }^{* * *} p<0.001$

Moving on to EU attitudes (table A.4.2.2), the results are identical to those in the article.

None of the interaction terms are statistically significant, and they also fail a joint test $(\mathrm{F}=.44, \mathrm{p}=.82)$. The explained variance does not increase at all.

Table A.4.2.2: Explaining EU Attitudes. OLS. Dummy offshorable variable.

\begin{tabular}{|c|c|c|c|c|}
\hline & $\begin{array}{c}1 \\
\text { Class and } \\
\text { education }\end{array}$ & $\begin{array}{c}2 \\
\text { Globalization } \\
\text { variables }\end{array}$ & $\begin{array}{c}3 \\
\text { Combined } \\
\text { model }\end{array}$ & $\begin{array}{c}4 \\
\text { Interaction } \\
\text { model }\end{array}$ \\
\hline Hi. serv. & $\begin{array}{c}-0.85^{* * *} \\
(0.12)\end{array}$ & & $\begin{array}{c}-0.74^{* * *} \\
(0.12)\end{array}$ & $\begin{array}{c}-0.75^{* * *} \\
(0.14)\end{array}$ \\
\hline Lo. serv. & $\begin{array}{c}-0.65^{* * *} \\
(0.11)\end{array}$ & & $\begin{array}{c}-0.51^{* * *} \\
(0.11)\end{array}$ & $\begin{array}{c}-0.55^{* * *} \\
(0.13)\end{array}$ \\
\hline Rout.nman & $\begin{array}{l}-0.34^{* *} \\
(0.11)\end{array}$ & & $\begin{array}{l}-0.28^{* *} \\
(0.11)\end{array}$ & $\begin{array}{l}-0.36^{* *} \\
(0.13)\end{array}$ \\
\hline Petite b. & $\begin{array}{c}-0.64^{* * *} \\
(0.15)\end{array}$ & & $\begin{array}{c}-0.57^{* * *} \\
(0.15)\end{array}$ & $\begin{array}{c}-0.67^{* * *} \\
(0.20)\end{array}$ \\
\hline Skilled w. & $\begin{array}{c}0.10 \\
(0.13)\end{array}$ & & $\begin{array}{c}0.07 \\
(0.12)\end{array}$ & $\begin{array}{c}0.01 \\
(0.14)\end{array}$ \\
\hline Medium edu & $\begin{array}{c}-0.35^{* * *} \\
(0.09)\end{array}$ & & $\begin{array}{c}-0.37^{\text {*** }} \\
(0.09)\end{array}$ & $\begin{array}{c}-0.38^{* * *} \\
(0.09)\end{array}$ \\
\hline Higher edu & $\begin{array}{c}-1.41^{* * *} \\
(0.10)\end{array}$ & & $\begin{array}{c}-1.33^{\text {*** }} \\
(0.10)\end{array}$ & $\begin{array}{c}-1.33^{* * *} \\
(0.10)\end{array}$ \\
\hline
\end{tabular}




\begin{tabular}{|c|c|c|c|c|}
\hline Intermediate & & $\begin{array}{c}-0.95^{\text {*** }} \\
(0.08)\end{array}$ & $\begin{array}{c}-0.75^{* * *} \\
(0.08)\end{array}$ & $\begin{array}{c}-0.75^{* * *} \\
(0.08)\end{array}$ \\
\hline Cosmopolitan & & $\begin{array}{c}-1.58^{* * *} \\
(0.09)\end{array}$ & $\begin{array}{c}-1.38^{* * *} \\
(0.09)\end{array}$ & $\begin{array}{c}-1.38^{* * *} \\
(0.09)\end{array}$ \\
\hline Offshoreable & & $\begin{array}{c}-0.31^{\text {*** }} \\
(0.06)\end{array}$ & $\begin{array}{l}-0.16^{*} \\
(0.06)\end{array}$ & $\begin{array}{l}-0.36 \\
(0.19)\end{array}$ \\
\hline $\begin{array}{l}\text { Hi. serv. \# } \\
\text { offshoreable }\end{array}$ & & & & $\begin{array}{c}0.14 \\
(0.23)\end{array}$ \\
\hline $\begin{array}{l}\text { Lo. serv. \# } \\
\text { offshoreable }\end{array}$ & & & & $\begin{array}{c}0.19 \\
(0.22)\end{array}$ \\
\hline $\begin{array}{l}\text { Rout.nman \# } \\
\text { offshoreable }\end{array}$ & & & & $\begin{array}{c}0.31 \\
(0.23)\end{array}$ \\
\hline $\begin{array}{l}\text { Petite b. \# } \\
\text { offshoreable }\end{array}$ & & & & $\begin{array}{c}0.28 \\
(0.31)\end{array}$ \\
\hline $\begin{array}{l}\text { Skilled w. \# } \\
\text { offshoreable }\end{array}$ & & & & $\begin{array}{c}0.26 \\
(0.28)\end{array}$ \\
\hline Female & $\begin{array}{c}0.39^{* * *} \\
(0.07)\end{array}$ & $\begin{array}{c}0.32^{* * *} \\
(0.06)\end{array}$ & $\begin{array}{c}0.33^{* * *} \\
(0.06)\end{array}$ & $\begin{array}{c}0.33^{* * * *} \\
(0.06)\end{array}$ \\
\hline Age & $\begin{array}{c}0.00 \\
(0.00)\end{array}$ & $\begin{array}{c}0.00 \\
(0.00)\end{array}$ & $\begin{array}{l}-0.00 \\
(0.00)\end{array}$ & $\begin{array}{l}-0.00 \\
(0.00)\end{array}$ \\
\hline Urban-rural & $\begin{array}{c}-0.07^{* * *} \\
(0.01)\end{array}$ & $\begin{array}{c}-0.07^{* * *} \\
(0.01)\end{array}$ & $\begin{array}{c}-0.05^{* * *} \\
(0.01)\end{array}$ & $\begin{array}{c}-0.05^{* * *} \\
(0.01)\end{array}$ \\
\hline Constant & $\begin{array}{l}6.56^{* * *} \\
(0.18)\end{array}$ & $\begin{array}{c}6.33^{* * *} \\
(0.14)\end{array}$ & $\begin{array}{c}6.97^{* * *} \\
(0.18)\end{array}$ & $\begin{array}{l}7.02^{* * *} \\
(0.18)\end{array}$ \\
\hline $\begin{array}{l}\text { Observations } \\
R^{2} \\
\text { Adjusted } R^{2}\end{array}$ & $\begin{array}{l}6935 \\
0.151 \\
0.149\end{array}$ & $\begin{array}{l}6935 \\
0.127 \\
0.126\end{array}$ & $\begin{array}{l}6935 \\
0.191 \\
0.188\end{array}$ & $\begin{array}{l}6935 \\
0.191 \\
0.188\end{array}$ \\
\hline
\end{tabular}

Standard errors in parentheses

${ }^{*} p<0.05,{ }^{* *} p<0.01,{ }^{* * *} p<0.001$

The same is true for immigration attitudes (table A.4.2.3). None of the interaction terms are statistically significant, and they also fail a joint test $(\mathrm{F}=1.27, \mathrm{p}=.27)$. The $\mathrm{R}^{2}$ essentially does not increase (it changes by 0.001 ).

Table A.4.2.3. Explaining Immigration Attitudes. OLS. Dummy offshorable variable.

\begin{tabular}{lcccc}
\hline & $\begin{array}{c}\text { Class and } \\
\text { education }\end{array}$ & $\begin{array}{c}\text { Globalization } \\
\text { variables }\end{array}$ & $\begin{array}{c}\text { Combined } \\
\text { model }\end{array}$ & $\begin{array}{c}\text { Interaction } \\
\text { model }\end{array}$ \\
\hline Hi. serv. & $0.44^{* * *}$ & & $0.37^{* * *}$ & $0.36^{* *}$
\end{tabular}


Lo. serv.

Rout.nman

Petite b.

0.01

(0.11)

$-0.00$

$-0.02$

(0.11)

Skilled w.

$-0.21^{*}$

(0.10)

$-0.18$

$-0.20$

(0.10)

(0.11)

Medium edu

$0.28^{* * * *}$

$0.30^{* * *}$

$0.30^{* * * *}$

(0.07)

(0.07)

(0.07)

Higher edu

$1.09^{* * *}$

(0.08)

$1.01^{* * *}$

(0.07)

$1.00^{* * * *}$ (0.07)

Intermediate

Cosmopolitan

$0.79^{* * *}$

(0.06)

$0.66^{* * * *}$

$0.66^{* * *}$

(0.06)

(0.06)

$1.45^{\text {*** }}$

$1.32^{* * *}$

$1.32^{\text {**** }}$

(0.07)

(0.07)

(0.07)

Offshoreable

$0.15^{* *}$

(0.05)

0.06

(0.05)

0.16

(0.16)

Hi. serv. \#

Offshoreable

Lo. serv. \#

Offshoreable

Rout.nman \#

Offshoreable

Petite b. \#

Offshoreable

Skilled w. \#

Offshoreable

Female

$0.13^{* *}$

$0.24^{* * *}$

$0.18^{* * * *}$

$0.17^{\text {**** }}$

(0.05)

(0.05)

(0.05)

(0.05)

Age

$-0.01^{\text {*** }}$

$-0.01^{* * *}$

$-0.01^{\text {*** }}$

$-0.01^{* * * *}$

(0.00)

(0.00)

(0.00)

Urban-rural

$0.07^{* * *}$

$0.08^{* * * *}$

$0.05^{* * *}$

$0.05^{\text {*** }}$

(0.01)

(0.01)

(0.01)

Constant

$3.52^{* * *}$

$3.57^{* * *}$

$3.15^{\text {*** }}$

$3.14^{* * * *}$

(0.11) 


\begin{tabular}{lcccc}
\hline Observations & 8084 & 8084 & 8084 & 8084 \\
$R^{2}$ & 0.152 & 0.151 & 0.201 & 0.202 \\
Adjusted $R^{2}$ & 0.150 & 0.149 & 0.199 & 0.199 \\
\hline
\end{tabular}

Standard errors in parentheses

${ }^{*} p<0.05,{ }^{* *} p<0.01,{ }^{* * *} p<0.001$

Finally, we replicate the results for party choice in table A.4.2.4. The results in model 2 and 3 mirror those in the article: Offshorability does seem to have a statistically significant, independent effect on party choice. Unlike table 4 in the article, there is also a statistically significant interaction effect $(p=.045)$. However, this seems to be of no substantial importance. The unadjusted McFadden's $\mathrm{R}^{2}$ increases by only 0.002 compared to the model with no interaction terms, and both the AIC and the BIC indicate that this model has substantially worse fit with the data than the model without interaction terms.

Table A.4.2.4. Overall significance of variables and goodness-of-fit for the multinomial logit models of party preference.

\begin{tabular}{lcccl}
\hline & $\begin{array}{c}1 \\
\text { Class and } \\
\text { education }\end{array}$ & $\begin{array}{c}\text { Globalization } \\
\text { variables }\end{array}$ & $\begin{array}{c}\text { Combined } \\
\text { model }\end{array}$ & $\begin{array}{c}\text { Interaction } \\
\text { model }\end{array}$ \\
\hline Class & $175.28^{* * *}$ & & $151.52^{* * *}$ & $95.80^{* * *}$ \\
Education & $116.98^{* * *}$ & & $104.14 * * *$ & $103.60^{* * *}$ \\
National ID & & $143.06^{* * *}$ & $117.70^{* * *}$ & $119.58^{* * *}$ \\
/Cosmopolitanism & & & & \\
Offshorability & & $60.70^{* * *}$ & $32.84 * * *$ & 4.48 \\
(dummy) & & & & $(\mathrm{p}=.61)$ \\
Class x & & & & $44.24 *$ \\
Offshorability & & & & $(\mathrm{p}=.045)$ \\
\hline McFadden's $R^{2}$ & 0.126 & 0.115 & 0.134 & 0.136 \\
AIC & 19452.507 & 19641.496 & 19315.117 & 19323.931 \\
BIC & 20216.990 & 20245.036 & 20200.308 & 20410.302 \\
\hline
\end{tabular}

Note: The Wald tests show the chi square value for the Wald test, with $p$ values in parentheses 


\section{A.4.3: Replications with the European Social Survey: Including a sector-based measure of globalization exposure (tradeable vs sheltered sector)}

In the article, and in line with other contributions to the field, we use the offshorability potential of an individual's job as a measure of globalization exposure. This was done both because the extant literature suggests that occupational labour market risks are more important than sector-specific risks, but also because this was the only measure available to us in the European Values Study. To make sure that our operationalization of globalization exposure does not affect our results, we replicate the analyses here using the first two waves of the European Social Survey. These waves contain a NACE scheme, and using replication material from Walter (2017), we were able to construct a variable that measures whether the individual works in a tradeable sector or a sheltered sector. This is another common indicator used in research on globalization exposure. We used the replication material from Walter (2017) to construct the offshorability index in the ESS as well, although in this replication we use a dummy of whether the person's job is offshorable or not, as in the robustness analyses in section A.4.2.

We replicate the analyses as closely as we can with the same nine countries as in the article. However, there are some differences due to the lack of suitable variables in the European Social Survey (which is why we used the European Values Study in the first place).

First, there is only one single item connected to economic left-right attitudes, namely a question about whether or not the state should reduce income differences. Respondents place themselves on a likert scale from 1 (agree strongly) to 5 (disagree strongly). We turn the scale so that a high value indicates a leftist orientation, as in the article. 
Second, there is only one item regarding the EU, namely a question of whether European integration has already gone too far or should go further. It should be noted that this measure is quite dissimilar from the multiple indicator measure of different EU fears that we apply in the article. Respondents place themselves on a scale from 0 (already gone too far) to 10 (unification should go further).

There are a number of different items concerning immigration. We have chosen the indicators that most closely match the ones we use in the EVS, namely questions about whether immigrants take jobs away or create new jobs; whether they enrich or undermine the country's cultural life; whether crime problems will get better or worse due to immigration; and finally whether it is necessary to stop immigration to reduce tensions in society. We construct an additive equal-weighted index based on these items (Cronbach's alpha 0.7), going from 0 (most skeptical of immigration) to 10 (most positive to immigration).

When it comes to party choice, we are mostly able to code the parties in the same way as in the article, although there are a few parties that do not exist in both data sets. These were relatively straight-forward to code (e.g. the Danish Progress Party being a Populist Right party). We are unfortunately unable to include a measure of cosmopolitanism versus national identity, as no such variable exists in the ESS. There is also no measure of the urban-rural residence of the respondent, so we leave out this control variable. We are, however, able to include age and sex.

We run a similar set of models as in the article. First, we show the relationship between class and education and each of the dependent variables, controlling for age and sex, 
and including country fixed effects. In the second, we include the two globalization variables: Offshorability and sector (tradeable versus non-tradeable). In the third, we combine class, education, and the globalization variables. In the fourth model, we add an interaction term between class and offshorability to the fourth model, replicating the results from the article. Finally, in the fifth model, we add an interaction term between class and sector (tradeable vs sheltered) to the fourth model.

Table A.4.3.1 shows the results for redistributive preferences, i.e. our replication of our results for economic left-right attitudes. Models 1-2 mirror our findings in the article: Class and education are associated with redistributive preferences, and offshorability has a weak effect. Sector does not affect redistributive preferences at all in this model, although in the combined model 3 , it has a very weak effect (a difference of 0.06 on a scale from 1-5). The fourth model reaffirms our findings from the article: All of the individual interaction terms as well as all of them together (a formal test yields $F=1.6$, $\mathrm{p}=.15)$ are insignificant, and the increase in adjusted $\mathrm{R} 2$ is marginal (0.01). Finally, in the fifth model, only one of the individual interaction terms between sector and class is significant (thus the joint test is also significant: $\mathrm{F}=2.6, \mathrm{p}=.02$ ). There is thus some suggestive evidence of an interaction between sector and class, although we note that the explained variance increases from $16.8 \%$ to $16.9 \%$ - in other words, this interaction does not seem to be substantially important.

Table A.4.3.1: Explaining Redistributive Preferences

\begin{tabular}{|c|c|c|c|c|c|}
\hline & $\begin{array}{c}1 \\
\text { Class and } \\
\text { education }\end{array}$ & $\begin{array}{c}2 \\
\text { Globalization } \\
\text { variables }\end{array}$ & $\begin{array}{c}3 \\
\text { Combined } \\
\text { model }\end{array}$ & $\begin{array}{c}4 \\
\text { Interaction: } \\
\text { Offshorability }\end{array}$ & $\begin{array}{c}5 \\
\text { Interaction: } \\
\text { Tradeable } \\
\text { sector }\end{array}$ \\
\hline Hi. serv. & $\begin{array}{c}-0.37^{* * *} \\
(0.04)\end{array}$ & & $\begin{array}{c}-0.35^{\text {*** }} \\
(0.05)\end{array}$ & $\begin{array}{c}-0.37^{* * *} \\
(0.05)\end{array}$ & $\begin{array}{c}-0.39^{* * *} \\
(0.05)\end{array}$ \\
\hline Lo. serv. & $\begin{array}{c}-0.18^{* * *} \\
(0.03)\end{array}$ & & $\begin{array}{c}-0.17^{\text {*** }} \\
(0.03)\end{array}$ & $\begin{array}{c}-0.11^{* *} \\
(0.04)\end{array}$ & $\begin{array}{c}-0.17^{\text {*** }} \\
(0.04)\end{array}$ \\
\hline
\end{tabular}




\begin{tabular}{|c|c|c|c|c|c|}
\hline Rout.nman & $\begin{array}{c}-0.10^{* * *} \\
(0.03)\end{array}$ & & $\begin{array}{l}-0.08^{*} \\
(0.03)\end{array}$ & $\begin{array}{l}-0.10^{* *} \\
(0.04)\end{array}$ & $\begin{array}{c}-0.11^{* *} \\
(0.04)\end{array}$ \\
\hline Petite bourg. & $\begin{array}{l}-0.11^{* *} \\
(0.04)\end{array}$ & & $\begin{array}{l}-0.11^{* *} \\
(0.04)\end{array}$ & $\begin{array}{l}-0.11^{*} \\
(0.04)\end{array}$ & $\begin{array}{c}-0.15^{* * *} \\
(0.04)\end{array}$ \\
\hline Skilled workers & $\begin{array}{c}0.02 \\
(0.04)\end{array}$ & & $\begin{array}{c}0.03 \\
(0.04)\end{array}$ & $\begin{array}{c}0.01 \\
(0.04)\end{array}$ & $\begin{array}{l}-0.05 \\
(0.05)\end{array}$ \\
\hline Medium edu & $\begin{array}{c}-0.15^{* * *} \\
(0.03)\end{array}$ & & $\begin{array}{c}-0.14^{* * *} \\
(0.03)\end{array}$ & $\begin{array}{c}-0.14^{* * *} \\
(0.03)\end{array}$ & $\begin{array}{c}-0.14^{* * *} \\
(0.03)\end{array}$ \\
\hline High edu & $\begin{array}{c}-0.28^{* * *} \\
(0.03)\end{array}$ & & $\begin{array}{c}-0.28^{* * *} \\
(0.03)\end{array}$ & $\begin{array}{c}-0.29^{* * *} \\
(0.03)\end{array}$ & $\begin{array}{c}-0.28^{* * *} \\
(0.03)\end{array}$ \\
\hline offshoreable & & $\begin{array}{c}-0.10^{* * *} \\
(0.02)\end{array}$ & $\begin{array}{l}-0.04 \\
(0.02)\end{array}$ & $\begin{array}{l}-0.03 \\
(0.07)\end{array}$ & $\begin{array}{l}-0.04 \\
(0.02)\end{array}$ \\
\hline $\begin{array}{l}\text { tradeable sector } \\
\text { (Dummy) }=1\end{array}$ & & $\begin{array}{l}-0.00 \\
(0.02)\end{array}$ & $\begin{array}{l}-0.06^{*} \\
(0.02)\end{array}$ & $\begin{array}{l}-0.06^{*} \\
(0.02)\end{array}$ & $\begin{array}{l}-0.13^{* *} \\
(0.04)\end{array}$ \\
\hline $\begin{array}{l}\text { Hi. serv. \# } \\
\text { offshoreable }\end{array}$ & & & & $\begin{array}{l}0.06 \\
(0.10)\end{array}$ & \\
\hline $\begin{array}{l}\text { Lo. serv. \# } \\
\text { offshoreable }\end{array}$ & & & & $\begin{array}{l}-0.11 \\
(0.08)\end{array}$ & \\
\hline $\begin{array}{l}\text { Rout.nman \# } \\
\text { offshoreable }\end{array}$ & & & & $\begin{array}{l}0.03 \\
(0.08)\end{array}$ & \\
\hline $\begin{array}{l}\text { Petite bourg. \# } \\
\text { offshoreable }\end{array}$ & & & & $\begin{array}{l}-0.01 \\
(0.09)\end{array}$ & \\
\hline $\begin{array}{l}\text { Skilled workers \# } \\
\text { offshoreable }\end{array}$ & & & & $\begin{array}{l}0.05 \\
(0.09)\end{array}$ & \\
\hline $\begin{array}{l}\text { Hi. serv. \# } \\
\text { tradeable sector } \\
(\text { Dummy) }=1\end{array}$ & & & & & $\begin{array}{l}0.13 \\
(0.09)\end{array}$ \\
\hline $\begin{array}{l}\text { Lo. serv. \# } \\
\text { tradeable sector } \\
(\text { Dummy) }=1\end{array}$ & & & & & $\begin{array}{l}-0.04 \\
(0.07)\end{array}$ \\
\hline $\begin{array}{l}\text { Rout.nman \# } \\
\text { tradeable sector } \\
\text { (Dummy) }=1\end{array}$ & & & & & $\begin{array}{l}0.13 \\
(0.07)\end{array}$ \\
\hline $\begin{array}{l}\text { Petite bourg. \# } \\
\text { tradeable sector }\end{array}$ & & & & & 0.13 \\
\hline
\end{tabular}


(Dummy) $=1$

\begin{tabular}{|c|c|c|c|c|c|}
\hline Female & $\begin{array}{c}0.17^{* * *} \\
(0.02)\end{array}$ & $\begin{array}{l}0.18^{* * *} \\
(0.02)\end{array}$ & $\begin{array}{c}0.15^{\text {*** }} \\
(0.02)\end{array}$ & $\begin{array}{c}0.15^{\text {**** }} \\
(0.02)\end{array}$ & $\begin{array}{c}0.15^{* * * *} \\
(0.02)\end{array}$ \\
\hline Age & $\begin{array}{c}0.00 \\
(0.00)\end{array}$ & $\begin{array}{l}0.00^{* * *} \\
(0.00)\end{array}$ & $\begin{array}{c}0.00 \\
(0.00)\end{array}$ & $\begin{array}{c}0.00 \\
(0.00)\end{array}$ & $\begin{array}{c}0.00 \\
(0.00)\end{array}$ \\
\hline Constant & $\begin{array}{l}3.84^{* * *} \\
(0.05)\end{array}$ & $\begin{array}{l}3.63^{* * * *} \\
(0.04) \\
\end{array}$ & $\begin{array}{c}3.84^{* * *} \\
(0.05)\end{array}$ & $\begin{array}{c}3.85^{* * * *} \\
(0.05) \\
\end{array}$ & $\begin{array}{c}3.87^{* * * *} \\
(0.05) \\
\end{array}$ \\
\hline Observations & 27692 & 26764 & 26764 & 26764 & 26764 \\
\hline$R^{2}$ & 0.169 & 0.140 & 0.168 & 0.169 & 0.169 \\
\hline Adjusted $R^{2}$ & 0.168 & 0.140 & 0.167 & 0.168 & 0.168 \\
\hline
\end{tabular}

Standard errors in parentheses

${ }^{*} p<0.05,{ }^{* *} p<0.01,{ }^{* * *} p<0.001$

In table A.4.3.2, we replicate the analyses of EU attitudes, in this case attitudes towards

EU integration. While the patterns are slightly less clear than in our article (probably because the dependent variable is only partly correlated to our multi-indicator measure), we find that class and education are associated with EU integration views, and education more so than class. The second model shows that people in offshorable occupations are slightly more positive to EU integration than people in non-offshorable occupations, while the pattern is the opposite for sector: People working in the tradeable sector are somewhat less positive to EU integration than those in sheltered sectors. In any case, model 3 demonstrates that this is likely just a spurious relationship caused by class and education, as both coefficients drop markedly and their standard errors become large.

The crucial models are again model 4 and 5 . In model 4, we see that none of the individual interaction terms are significant, and a formal test of all of them yields $\mathrm{F}=$ $.94, p=.46$. The same is true of model 5 : None of the interaction terms are statistically 
significant, and a joint test yields $\mathrm{F}=1.07, \mathrm{p}=.38$. In other words, including sectoral exposure to globalization does not alter our conclusions.

Table A.4.3.2: Explaining EU Integration Views

\begin{tabular}{|c|c|c|c|c|c|}
\hline & $\begin{array}{c}1 \\
\text { Class and } \\
\text { education }\end{array}$ & $\begin{array}{c}2 \\
\text { Globalization } \\
\text { variables }\end{array}$ & $\begin{array}{c}3 \\
\text { Combined } \\
\text { model }\end{array}$ & $\begin{array}{c}4 \\
\text { Interaction: } \\
\text { Offshorability }\end{array}$ & $\begin{array}{c}5 \\
\text { Interaction: } \\
\text { Tradeable } \\
\text { sector }\end{array}$ \\
\hline Hi. serv. & $\begin{array}{l}0.42^{* *} \\
(0.15)\end{array}$ & & $\begin{array}{l}0.40^{* *} \\
(0.15)\end{array}$ & $\begin{array}{l}0.36^{*} \\
(0.16)\end{array}$ & $\begin{array}{l}0.38^{*} \\
(0.18)\end{array}$ \\
\hline Lo. serv. & $\begin{array}{l}0.32^{*} \\
(0.13)\end{array}$ & & $\begin{array}{l}0.29^{*} \\
(0.13)\end{array}$ & $\begin{array}{c}0.27 \\
(0.16)\end{array}$ & $\begin{array}{l}0.28 \\
(0.15)\end{array}$ \\
\hline Rout.nman & $\begin{array}{l}0.25^{*} \\
(0.11)\end{array}$ & & $\begin{array}{c}0.23 \\
(0.12)\end{array}$ & $\begin{array}{c}0.23 \\
(0.15)\end{array}$ & $\begin{array}{l}0.18 \\
(0.15)\end{array}$ \\
\hline Petite bourg. & $\begin{array}{c}0.14 \\
(0.14)\end{array}$ & & $\begin{array}{c}0.17 \\
(0.14)\end{array}$ & $\begin{array}{c}0.02 \\
(0.16)\end{array}$ & $\begin{array}{c}0.27 \\
(0.18)\end{array}$ \\
\hline Skilled workers & $\begin{array}{l}-0.13 \\
(0.15)\end{array}$ & & $\begin{array}{l}-0.09 \\
(0.15)\end{array}$ & $\begin{array}{l}-0.23 \\
(0.17)\end{array}$ & $\begin{array}{l}-0.27 \\
(0.20)\end{array}$ \\
\hline Medium edu & $\begin{array}{l}0.16 \\
(0.10)\end{array}$ & & $\begin{array}{l}0.15 \\
(0.10)\end{array}$ & $\begin{array}{c}0.15 \\
(0.10)\end{array}$ & $\begin{array}{l}0.14 \\
(0.10)\end{array}$ \\
\hline High edu & $\begin{array}{l}0.82^{* * *} \\
(0.12)\end{array}$ & & $\begin{array}{l}0.83^{* * *} \\
(0.12)\end{array}$ & $\begin{array}{l}0.82^{* * *} \\
(0.12)\end{array}$ & $\begin{array}{l}0.82^{* * * *} \\
(0.12)\end{array}$ \\
\hline offshoreable & & $\begin{array}{l}0.17^{*} \\
(0.08)\end{array}$ & $\begin{array}{c}0.03 \\
(0.08)\end{array}$ & $\begin{array}{l}-0.30 \\
(0.23)\end{array}$ & $\begin{array}{c}0.01 \\
(0.08)\end{array}$ \\
\hline $\begin{array}{l}\text { tradeable sector } \\
\text { (Dummy) }=1\end{array}$ & & $\begin{array}{l}-0.24^{* * *} \\
(0.09)\end{array}$ & $\begin{array}{l}-0.10 \\
(0.09)\end{array}$ & $\begin{array}{l}-0.09 \\
(0.09)\end{array}$ & $\begin{array}{l}-0.16 \\
(0.17)\end{array}$ \\
\hline $\begin{array}{l}\text { Hi. serv. \# } \\
\text { offshoreable }\end{array}$ & & & & $\begin{array}{l}0.33 \\
(0.31)\end{array}$ & \\
\hline $\begin{array}{l}\text { Lo. serv. \# } \\
\text { offshoreable }\end{array}$ & & & & $\begin{array}{l}0.30 \\
(0.28)\end{array}$ & \\
\hline $\begin{array}{l}\text { Rout.nman \# } \\
\text { offshoreable }\end{array}$ & & & & $\begin{array}{l}0.26 \\
(0.27)\end{array}$ & \\
\hline $\begin{array}{l}\text { Petite bourg. \# } \\
\text { offshoreable }\end{array}$ & & & & $\begin{array}{l}0.63 \\
(0.33)\end{array}$ & \\
\hline $\begin{array}{l}\text { Skilled workers \# } \\
\text { offshoreable }\end{array}$ & & & & $\begin{array}{l}0.60 \\
(0.36)\end{array}$ & \\
\hline
\end{tabular}




\begin{tabular}{|c|c|c|c|c|c|}
\hline Female & $\begin{array}{c}-0.33^{* * *} \\
(0.08)\end{array}$ & $\begin{array}{c}-0.34^{* * *} \\
(0.08)\end{array}$ & $\begin{array}{c}-0.33^{* * *} \\
(0.08)\end{array}$ & $\begin{array}{c}-0.34^{* * *} \\
(0.08)\end{array}$ & $\begin{array}{c}-0.34^{* * * *} \\
(0.08)\end{array}$ \\
\hline Age & $\begin{array}{l}-0.01^{*} \\
(0.00)\end{array}$ & $\begin{array}{c}-0.01^{* * *} \\
(0.00)\end{array}$ & $\begin{array}{l}-0.01^{*} \\
(0.00)\end{array}$ & $\begin{array}{l}-0.01^{*} \\
(0.00)\end{array}$ & $\begin{array}{l}-0.01^{*} \\
(0.00)\end{array}$ \\
\hline Constant & $\begin{array}{c}4.69^{* * *} \\
(0.16) \\
\end{array}$ & $\begin{array}{l}5.15^{* * *} \\
(0.13) \\
\end{array}$ & $\begin{array}{c}4.71^{* * *} \\
(0.17)\end{array}$ & $\begin{array}{c}4.78^{* * *} \\
(0.17) \\
\end{array}$ & $\begin{array}{c}4.74^{* * *} \\
(0.18) \\
\end{array}$ \\
\hline Observations & 13169 & 12811 & 12811 & 12811 & 12811 \\
\hline$R^{2}$ & 0.065 & 0.041 & 0.065 & 0.066 & 0.066 \\
\hline Adjusted $R^{2}$ & 0.064 & 0.040 & 0.064 & 0.064 & 0.064 \\
\hline
\end{tabular}

Standard errors in parentheses

${ }^{*} p<0.05,{ }^{* *} p<0.01,{ }^{* * *} p<0.001$

In table A.4.3.3, we replicate the analyses of immigration attitudes. The first model mirrors the findings in the article: Class and education are related to immigration attitudes, although education is much more important. The second model shows that people in offshorable occupations are slightly more positive to immigration, while people in the tradeable sector are more negative. The latter coefficients is halved in the third model when class and education are included, while the effect of offshorability disappears completely. 
Model 4 yields the same conclusions as in the article: Not a single interaction term is statistically significant and a joint test yields $F=1.4, p=.24$. The same is true for the sectoral model 5: Not one of the interaction terms between sector and class are significant, and a joint test yields $\mathrm{F}=1.5, \mathrm{p}=.19$.

Table A.4.3.3: Explaining immigration orientations

\begin{tabular}{|c|c|c|c|c|c|}
\hline & $\begin{array}{c}1 \\
\text { Class and } \\
\text { education }\end{array}$ & $\begin{array}{c}2 \\
\text { Globalization } \\
\text { variables }\end{array}$ & $\begin{array}{c}3 \\
\text { Combined } \\
\text { model }\end{array}$ & $\begin{array}{c}4 \\
\text { Interaction: } \\
\text { Offshorability }\end{array}$ & $\begin{array}{c}5 \\
\text { Interaction: } \\
\text { Tradeable } \\
\text { sector }\end{array}$ \\
\hline Hi. serv. & $\begin{array}{c}0.14 \\
(0.10)\end{array}$ & & $\begin{array}{c}0.13 \\
(0.10)\end{array}$ & $\begin{array}{c}0.12 \\
(0.12)\end{array}$ & $\begin{array}{c}0.22 \\
(0.12)\end{array}$ \\
\hline Lo. serv. & $\begin{array}{c}0.33^{* * *} \\
(0.09)\end{array}$ & & $\begin{array}{l}0.31^{* *} \\
(0.10)\end{array}$ & $\begin{array}{l}0.33^{* *} \\
(0.11)\end{array}$ & $\begin{array}{l}0.34^{* * *} \\
(0.11)\end{array}$ \\
\hline Rout.nman & $\begin{array}{l}0.16^{*} \\
(0.08)\end{array}$ & & $\begin{array}{c}0.11 \\
(0.09)\end{array}$ & $\begin{array}{c}0.05 \\
(0.10)\end{array}$ & $\begin{array}{c}0.09 \\
(0.10)\end{array}$ \\
\hline Petite bourg. & $\begin{array}{l}-0.05 \\
(0.09)\end{array}$ & & $\begin{array}{l}-0.04 \\
(0.09)\end{array}$ & $\begin{array}{l}-0.08 \\
(0.11)\end{array}$ & $\begin{array}{l}-0.05 \\
(0.12)\end{array}$ \\
\hline Skilled workers & $\begin{array}{l}-0.15 \\
(0.11)\end{array}$ & & $\begin{array}{l}-0.14 \\
(0.11)\end{array}$ & $\begin{array}{c}0.01 \\
(0.13)\end{array}$ & $\begin{array}{l}-0.19 \\
(0.14)\end{array}$ \\
\hline Medium edu & $\begin{array}{c}0.41^{* * * *} \\
(0.06)\end{array}$ & & $\begin{array}{l}0.41^{* * * *} \\
(0.07)\end{array}$ & $\begin{array}{l}0.40^{* * * *} \\
(0.07)\end{array}$ & $\begin{array}{c}0.40^{* * * *} \\
(0.07)\end{array}$ \\
\hline High edu & $\begin{array}{l}1.11^{* * *} \\
(0.07)\end{array}$ & & $\begin{array}{l}1.09^{* * *} \\
(0.07)\end{array}$ & $\begin{array}{l}1.08^{* * * *} \\
(0.08)\end{array}$ & $\begin{array}{l}1.08^{* * * *} \\
(0.07)\end{array}$ \\
\hline offshoreable & & $\begin{array}{c}0.18^{* * * *} \\
(0.05)\end{array}$ & $\begin{array}{c}0.01 \\
(0.06)\end{array}$ & $\begin{array}{l}-0.01 \\
(0.20)\end{array}$ & $\begin{array}{c}0.01 \\
(0.06)\end{array}$ \\
\hline $\begin{array}{l}\text { tradeable sector } \\
\text { (Dummy) }=1\end{array}$ & & $\begin{array}{c}-0.40^{* * *} \\
(0.06)\end{array}$ & $\begin{array}{c}-0.23^{* * *} \\
(0.06)\end{array}$ & $\begin{array}{c}-0.22^{* * *} \\
(0.06)\end{array}$ & $\begin{array}{l}-0.20 \\
(0.14)\end{array}$ \\
\hline $\begin{array}{l}\text { Hi. serv. \# } \\
\text { offshoreable }\end{array}$ & & & & $\begin{array}{l}0.04 \\
(0.23)\end{array}$ & \\
\hline $\begin{array}{l}\text { Lo. serv. \# } \\
\text { offshoreable }\end{array}$ & & & & $\begin{array}{l}-0.02 \\
(0.22)\end{array}$ & \\
\hline $\begin{array}{l}\text { Rout.nman \# } \\
\text { offshoreable }\end{array}$ & & & & $\begin{array}{l}0.14 \\
(0.22)\end{array}$ & \\
\hline $\begin{array}{l}\text { Petite bourg. \# } \\
\text { offshoreable }\end{array}$ & & & & 0.12 & \\
\hline
\end{tabular}


Skilled workers \#

offshoreable

Hi. serv. \#

tradeable sector

(Dummy) $=1$

Lo. serv. \#

tradeable sector

(Dummy) $=1$

Rout.nman \#

tradeable sector

(Dummy) $=1$

Petite bourg. \#

Skilled workers \#

tradeable sector

(Dummy) $=1$

\begin{tabular}{lccccc} 
Female & -0.07 & -0.08 & -0.08 & -0.08 & -0.09 \\
& $(0.05)$ & $(0.05)$ & $(0.05)$ & $(0.05)$ & $(0.05)$ \\
Age & & & & & \\
& $-0.01^{* * *}$ & $-0.01^{* * *}$ & $-0.01^{* * *}$ & $-0.01^{* * *}$ & $-0.01^{* * *}$ \\
& $(0.00)$ & $(0.00)$ & $(0.00)$ & $(0.00)$ & $(0.00)$ \\
Constant & & & & & \\
& $4.53^{* * *}$ & $5.33^{* * *}$ & $4.61^{* * *}$ & $4.61^{* * *}$ & $4.61^{* * *}$ \\
\hline Observations & $(0.11)$ & $(0.09)$ & $(0.12)$ & $(0.12)$ & $(0.12)$ \\
$R^{2}$ & 13088 & 12569 & 12569 & 12569 & 12569 \\
Adjusted $R^{2}$ & 0.184 & 0.106 & 0.186 & 0.188 & 0.187 \\
\hline
\end{tabular}

Standard errors in parentheses

${ }^{*} p<0.05,{ }^{* *} p<0.01,{ }^{* * *} p<0.001$

In summary, then, there is little evidence that globalization has taken over as the new

cleavage. In data from the ESS, just like in our data from the EVS, offshorability has no important independent effect on any of the political attitudes and there is no significant interaction between class and offshorability. Whether one works in a tradeable or sheltered sector has a very weak independent effect on redistributive preferences, no effect on EU integration views, and a weak/moderate effect on immigration attitudes. 
There is no interaction with class for EU integration attitudes or immigration attitudes, however there is some evidence of a limited and substantially unimportant interaction effect on redistributive preferences.

Finally, we replicate table 4 from the article, predicting party choice (see table A.4.3.4 below). Model 1-3 mirror the results from the article. Class, education, offshorability and now also tradeability - have statistically significant effects on party choice.

Model 4, contrary to the results in our article, now suggests that there is in fact an interaction effect between class and offshorability. However, statistical significance is one question, substantial importance another. Including the interaction term essentially does not increase the pseudo $\mathrm{R}^{2}$ compared to model 4 with no interaction. The AIC is reduced by 1.66 , a change which according to Raftory (1995) indicates weak evidence that this model is to be preferred. However, the BIC (which takes into account that the interaction term introduces a range of new coefficients) increases by more than 200 , which is considered very strong evidence that model 3 fits better.

Similarly, model 5 indicates that there is a statistically significant interaction between class and sector when explaining party choice. Yet again the pseudo $\mathrm{R}^{2}$ only increases by 0.001 , and the changes in AIC and BIC are similar to above. In sum, there is evidence that class is interacting with globalization exposure when predicting party choice, but the substantial importance of this interaction term seems to be very limited. It is certainly too limited to make any broad claims about cross-cutting cleavages or cross-class alliances due to globalization exposure. 
Table A.4.3.4. Overall significance of variables and goodness-of-fit for the multinomial logit models of party preference.

\begin{tabular}{|c|c|c|c|c|c|}
\hline & $\begin{array}{c}1 \\
\text { Class and } \\
\text { education }\end{array}$ & $\begin{array}{c}2 \\
\text { Globalization } \\
\text { variables }\end{array}$ & $\begin{array}{c}3 \\
\text { Combined } \\
\text { model }\end{array}$ & $\begin{array}{c}4 \\
\text { Interaction } \\
\text { class- } \\
\text { offshorability }\end{array}$ & $\begin{array}{c}5 \\
\text { Interaction } \\
\text { class- } \\
\text { sector }\end{array}$ \\
\hline Class & $286.66 * * *$ & & $268.25 * * *$ & $173.93 * * *$ & $167.25 * * *$ \\
\hline Education & $292.74 * * *$ & & $292.05 * * *$ & $291.05 * * *$ & $293.79 * * *$ \\
\hline Sector (trade) & & $58.37 * * *$ & $49.06 * * *$ & $53.97 * * *$ & $18.68 * *$ \\
\hline Offshorability & & $55.76^{* * *}$ & $22.04 * *$ & $18.28 * *$ & $20.00 * *$ \\
\hline Class x & & & & $60.67 * *$ & \\
\hline \multicolumn{6}{|l|}{ Offshorability } \\
\hline Class $\mathrm{x}$ sector & & & & & $59.42 * *$ \\
\hline McFadden's & 0.110 & 0.094 & 0.112 & 0.113 & 0.113 \\
\hline \multicolumn{6}{|l|}{$R^{2}$} \\
\hline AIC & 45206.610 & 45939.190 & 45151.235 & 45149.570 & 45151.144 \\
\hline BIC & 45982.541 & 46464.084 & 46018.452 & 46245.003 & 46246.576 \\
\hline
\end{tabular}

Note: The Wald tests show the chi square value for the Wald test, with $p$ values in parentheses.

\section{A.5: The country-specific analyses}

\section{A.5.1: Country specific analyses of economic left-right attitudes}

Table A.5.1.1: Explaining Economic Attitudes in Austria

\begin{tabular}{|c|c|c|c|c|}
\hline & $\begin{array}{c}1 \\
\text { Class \& } \\
\text { education }\end{array}$ & $\begin{array}{c}2 \\
\text { Globalization } \\
\text { model }\end{array}$ & $\begin{array}{c}3 \\
\text { Combined } \\
\text { model }\end{array}$ & $\begin{array}{c}4 \\
\begin{array}{c}\text { Interaction } \\
\text { model }\end{array} \\
\end{array}$ \\
\hline Hi. serv. & $\begin{array}{c}-0.59^{* *} \\
(0.22)\end{array}$ & & $\begin{array}{c}-0.56^{* *} \\
(0.22)\end{array}$ & $\begin{array}{c}-0.49^{*} \\
(0.22)\end{array}$ \\
\hline Lo. serv. & $\begin{array}{l}-0.50^{*} \\
(0.20)\end{array}$ & & $\begin{array}{l}-0.45^{*} \\
(0.20)\end{array}$ & $\begin{array}{l}-0.54^{*} \\
(0.23)\end{array}$ \\
\hline Rout.nman & $\begin{array}{l}-0.05 \\
(0.18)\end{array}$ & & $\begin{array}{l}-0.02 \\
(0.18)\end{array}$ & $\begin{array}{l}-0.04 \\
(0.19)\end{array}$ \\
\hline
\end{tabular}


Petite b. $\quad-0.37$

(0.24)

Skilled w.

$-0.17$

(0.22)

$-0.14$

Medium edu

(0.16)

Higher edu

$-0.22$

(0.23)

Intermediate

Cosmopolitan

Offshorability

Hi. serv. \#

Offshorability

Lo. serv. \#

Offshorability

Offshorability

Petite b. \# Offshorability

Skilled w. \#

Offshorability
Rout.nman \#

$\begin{array}{lc}-0.29 & 0.15 \\ (0.25) & (0.31)\end{array}$

$-0.12$

$-0.13$

(0.22)

(0.24)

$-0.13$

$-0.09$

(0.16)

(0.16)

$-0.27$

$-0.25$

(0.23)

(0.23)

$-0.10$

(0.14)

0.01

(0.14)

0.01

0.32

$0.37^{*}$

(0.14)

(0.17)

(0.17)

$0.38^{*}$

(0.17)

$-0.03$

(0.02)

$-0.02$

(0.02)

0.08

(0.14)

$-0.15$

(0.15)

$-0.07$

(0.15)

$-0.09$

(0.14)

$-0.22$

(0.16)

$-0.09$

(0.15)

Female

0.18

$(0.11)$

$0.28^{* *}$

(0.10)

0.19

0.19

(0.11)

(0.11)

Age

$-0.00$

(0.00)

$-0.00$

(0.00)

$-0.00$

$-0.00$

(0.00)

(0.00)

Urban-rural

0.02

(0.02)

0.01

(0.02)

0.01

0.01

(0.02)

(0.02)

\begin{tabular}{lcccc} 
Constant & $4.97^{* * *}$ & $4.55^{* * *}$ & $4.82^{* * *}$ & $4.81^{* * *}$ \\
& $(0.27)$ & $(0.20)$ & $(0.28)$ & $(0.28)$ \\
\hline Observations & 960 & 960 & 960 & 960 \\
$R^{2}$ & 0.037 & 0.021 & 0.044 & 0.050 \\
Adjusted $R^{2}$ & 0.027 & 0.015 & 0.031 & 0.032 \\
\hline
\end{tabular}

Standard errors in parentheses

${ }^{*} p<0.05,{ }^{* *} p<0.01,{ }^{* * *} p<0.001$ 
Table A.5.1.2: Explaining Economic Attitudes in France

\begin{tabular}{|c|c|c|c|c|}
\hline & $\begin{array}{c}1 \\
\text { Class \& } \\
\text { education }\end{array}$ & $\begin{array}{c}2 \\
\text { Globalization } \\
\text { model }\end{array}$ & $\begin{array}{c}3 \\
\text { Combined } \\
\text { model }\end{array}$ & $\begin{array}{c}4 \\
\text { Interaction } \\
\text { model } \\
\end{array}$ \\
\hline Hi. serv. & $\begin{array}{c}-0.59^{* *} \\
(0.21)\end{array}$ & & $\begin{array}{l}-0.50^{*} \\
(0.22)\end{array}$ & $\begin{array}{l}-0.39 \\
(0.30)\end{array}$ \\
\hline Lo. serv. & $\begin{array}{l}-0.24 \\
(0.17)\end{array}$ & & $\begin{array}{l}-0.19 \\
(0.17)\end{array}$ & $\begin{array}{c}0.18 \\
(0.21)\end{array}$ \\
\hline Rout.nman & $\begin{array}{l}-0.15 \\
(0.16)\end{array}$ & & $\begin{array}{l}-0.10 \\
(0.16)\end{array}$ & $\begin{array}{c}0.13 \\
(0.20)\end{array}$ \\
\hline Petite $b$. & $\begin{array}{c}-0.93^{* * *} \\
(0.23)\end{array}$ & & $\begin{array}{c}-0.84^{* * *} \\
(0.24)\end{array}$ & $\begin{array}{l}-0.74^{*} \\
(0.34)\end{array}$ \\
\hline Skilled w. & $\begin{array}{l}-0.12 \\
(0.18)\end{array}$ & & $\begin{array}{l}-0.09 \\
(0.18)\end{array}$ & $\begin{array}{l}-0.17 \\
(0.21)\end{array}$ \\
\hline Medium edu & $\begin{array}{l}-0.19 \\
(0.14)\end{array}$ & & $\begin{array}{l}-0.20 \\
(0.14)\end{array}$ & $\begin{array}{l}-0.20 \\
(0.14)\end{array}$ \\
\hline Higher edu & $\begin{array}{l}-0.41^{*} \\
(0.18)\end{array}$ & & $\begin{array}{l}-0.46^{* * *} \\
(0.18)\end{array}$ & $\begin{array}{l}-0.47^{* * *} \\
(0.18)\end{array}$ \\
\hline Intermediate & & $\begin{array}{l}-0.12 \\
(0.14)\end{array}$ & $\begin{array}{l}-0.00 \\
(0.14)\end{array}$ & $\begin{array}{c}0.02 \\
(0.14)\end{array}$ \\
\hline Cosmopolitan & & $\begin{array}{c}0.26 \\
(0.14)\end{array}$ & $\begin{array}{l}0.35^{*} \\
(0.14)\end{array}$ & $\begin{array}{l}0.37^{* *} \\
(0.14)\end{array}$ \\
\hline Offshorability & & $\begin{array}{c}-0.05^{* * *} \\
(0.01)\end{array}$ & $\begin{array}{l}-0.03^{*} \\
(0.02)\end{array}$ & $\begin{array}{c}0.06 \\
(0.04)\end{array}$ \\
\hline $\begin{array}{l}\text { Hi. serv. \# } \\
\text { Offshorability }\end{array}$ & & & & $\begin{array}{l}-0.08 \\
(0.06)\end{array}$ \\
\hline $\begin{array}{l}\text { Lo. serv. \# } \\
\text { Offshorability }\end{array}$ & & & & $\begin{array}{l}-0.15^{* *} \\
(0.05)\end{array}$ \\
\hline $\begin{array}{l}\text { Rout.nman \# } \\
\text { Offshorability }\end{array}$ & & & & $\begin{array}{l}-0.11^{*} \\
(0.05)\end{array}$ \\
\hline Petite b. \# Offshorability & & & & $\begin{array}{l}-0.08 \\
(0.08)\end{array}$ \\
\hline $\begin{array}{l}\text { Skilled w. \# } \\
\text { Offshorability }\end{array}$ & & & & $\begin{array}{l}0.00 \\
(0.06)\end{array}$ \\
\hline Female & $\begin{array}{c}0.17 \\
(0.11)\end{array}$ & $\begin{array}{l}0.21^{*} \\
(0.10)\end{array}$ & $\begin{array}{c}0.17 \\
(0.11)\end{array}$ & $\begin{array}{c}0.13 \\
(0.11)\end{array}$ \\
\hline Age & $\begin{array}{l}-0.00 \\
(0.00)\end{array}$ & $\begin{array}{l}-0.00 \\
(0.00)\end{array}$ & $\begin{array}{l}-0.00 \\
(0.00)\end{array}$ & $\begin{array}{l}-0.00 \\
(0.00)\end{array}$ \\
\hline Urban-rural & 0.02 & 0.01 & 0.01 & 0.02 \\
\hline
\end{tabular}




\begin{tabular}{|c|c|c|c|c|}
\hline residence & $(0.02)$ & $(0.02)$ & $(0.02)$ & $(0.02)$ \\
\hline Constant & $\begin{array}{l}5.02^{* * *} \\
(0.25) \\
\end{array}$ & $\begin{array}{l}4.58^{* * *} \\
(0.18) \\
\end{array}$ & $\begin{array}{l}5.01^{* * *} \\
(0.25) \\
\end{array}$ & $\begin{array}{l}4.86^{* * *} \\
(0.26)\end{array}$ \\
\hline Observations & 1123 & 1123 & 1123 & 1123 \\
\hline$R^{2}$ & 0.042 & 0.021 & 0.053 & 0.065 \\
\hline Adjusted $R^{2}$ & 0.033 & 0.016 & 0.042 & 0.049 \\
\hline \multicolumn{5}{|c|}{$\begin{array}{l}\text { Standard errors in parentheses } \\
{ }^{*} p<0.05,{ }^{* *} p<0.01,{ }^{* * *} p<0.001\end{array}$} \\
\hline \multicolumn{5}{|c|}{ Table A.5.1.3: Explaining Economic Attitudes in Germany } \\
\hline & $\begin{array}{c}1 \\
\text { Class \& } \\
\text { education } \\
\end{array}$ & $\begin{array}{c}2 \\
\begin{array}{c}\text { Globalization } \\
\text { model }\end{array} \\
\end{array}$ & $\begin{array}{c}3 \\
\text { Combined } \\
\text { model }\end{array}$ & $\begin{array}{c}4 \\
\text { Interaction } \\
\text { model }\end{array}$ \\
\hline Hi. serv. & $\begin{array}{l}-0.66^{*} \\
(0.29)\end{array}$ & & $\begin{array}{l}-0.71^{*} \\
(0.29)\end{array}$ & $\begin{array}{l}-0.50 \\
(0.34)\end{array}$ \\
\hline Lo. serv. & $\begin{array}{l}-0.78^{* * *} \\
(0.21)\end{array}$ & & $\begin{array}{l}-0.79^{* * *} \\
(0.21)\end{array}$ & $\begin{array}{l}-0.65^{* *} \\
(0.24)\end{array}$ \\
\hline Rout.nman & $\begin{array}{l}-0.59^{* *} \\
(0.21)\end{array}$ & & $\begin{array}{l}-0.56^{* *} \\
(0.21)\end{array}$ & $\begin{array}{l}-0.44 \\
(0.24)\end{array}$ \\
\hline Petite b. & $\begin{array}{l}-0.76^{*} \\
(0.35)\end{array}$ & & $\begin{array}{l}-0.73^{*} \\
(0.34)\end{array}$ & $\begin{array}{l}-1.03^{*} \\
(0.47)\end{array}$ \\
\hline Skilled w. & $\begin{array}{l}-0.12 \\
(0.21)\end{array}$ & & $\begin{array}{l}-0.09 \\
(0.21)\end{array}$ & $\begin{array}{l}-0.17 \\
(0.24)\end{array}$ \\
\hline Medium edu & $\begin{array}{l}-0.21 \\
(0.21)\end{array}$ & & $\begin{array}{l}-0.17 \\
(0.21)\end{array}$ & $\begin{array}{l}-0.12 \\
(0.21)\end{array}$ \\
\hline Higher edu & $\begin{array}{l}-0.42 \\
(0.25)\end{array}$ & & $\begin{array}{l}-0.40 \\
(0.25)\end{array}$ & $\begin{array}{l}-0.35 \\
(0.25)\end{array}$ \\
\hline Intermediate & & $\begin{array}{c}0.19 \\
(0.17)\end{array}$ & $\begin{array}{c}0.25 \\
(0.16)\end{array}$ & $\begin{array}{c}0.23 \\
(0.16)\end{array}$ \\
\hline Cosmopolitan & & $\begin{array}{c}0.30 \\
(0.18)\end{array}$ & $\begin{array}{l}0.37^{*} \\
(0.18)\end{array}$ & $\begin{array}{c}0.37^{*} \\
(0.18)\end{array}$ \\
\hline Offshorability & & $\begin{array}{l}-0.02 \\
(0.02)\end{array}$ & $\begin{array}{l}-0.01 \\
(0.02)\end{array}$ & $\begin{array}{c}0.04 \\
(0.05)\end{array}$ \\
\hline $\begin{array}{l}\text { Hi. serv. \# } \\
\text { Offshorability }\end{array}$ & & & & $\begin{array}{l}-0.11 \\
(0.08)\end{array}$ \\
\hline $\begin{array}{l}\text { Lo. serv. \# } \\
\text { Offshorability }\end{array}$ & & & & $\begin{array}{l}-0.08 \\
(0.07)\end{array}$ \\
\hline $\begin{array}{l}\text { Rout.nman \# } \\
\text { Offshorability }\end{array}$ & & & & $\begin{array}{l}-0.08 \\
(0.07)\end{array}$ \\
\hline Petite b. \# Offshorability & & & & $\begin{array}{c}0.05 \\
(0.12)\end{array}$ \\
\hline Skilled w. \# & & & & 0.01 \\
\hline
\end{tabular}


Offshorability

$(0.07)$

\begin{tabular}{lcccc} 
Female & $0.30^{*}$ & 0.21 & $0.29^{*}$ & 0.25 \\
& $(0.15)$ & $(0.13)$ & $(0.15)$ & $(0.15)$ \\
Age & & & -0.01 & -0.01 \\
& $(0.01$ & -0.01 & $(0.00)$ & $(0.00)$ \\
Urban-rural & & $(0.00)$ & 0.01 & 0.01 \\
residence & 0.02 & 0.01 & $(0.04)$ & $(0.04)$ \\
Constant & $(0.04)$ & $(0.04)$ & & $4.89^{* * *}$ \\
& & & & $(0.37)$ \\
\hline Observations & $5.08^{* * *}$ & $4.42^{* * *}$ & $(0.36)$ & 825 \\
$R^{2}$ & $(0.36)$ & $(0.27)$ & 825 & 0.084 \\
Adjusted $R^{2}$ & 825 & 825 & 0.076 & 0.063 \\
\hline
\end{tabular}

Standard errors in parentheses

${ }^{*} p<0.05,{ }^{* *} p<0.01,{ }^{* * *} p<0.001$

Table A.5.1.4: Explaining Economic Attitudes in the Netherlands

\begin{tabular}{|c|c|c|c|c|}
\hline & $\begin{array}{c}1 \\
\text { Class \& } \\
\text { education }\end{array}$ & $\begin{array}{c}2 \\
\text { Globalization } \\
\text { model }\end{array}$ & $\begin{array}{c}3 \\
\text { Combined } \\
\text { model }\end{array}$ & $\begin{array}{c}4 \\
\text { Interaction } \\
\text { model }\end{array}$ \\
\hline Hi. serv. & $\begin{array}{c}-0.46^{* *} \\
(0.17)\end{array}$ & & $\begin{array}{c}-0.46^{* *} \\
(0.17)\end{array}$ & $\begin{array}{c}-0.49^{*} \\
(0.20)\end{array}$ \\
\hline Lo. serv. & $\begin{array}{l}-0.16 \\
(0.16)\end{array}$ & & $\begin{array}{l}-0.16 \\
(0.16)\end{array}$ & $\begin{array}{l}-0.01 \\
(0.20)\end{array}$ \\
\hline Rout.nman & $\begin{array}{l}-0.08 \\
(0.15)\end{array}$ & & $\begin{array}{l}-0.07 \\
(0.15)\end{array}$ & $\begin{array}{l}-0.03 \\
(0.19)\end{array}$ \\
\hline Petite b. & $\begin{array}{c}-0.98^{* * *} \\
(0.20)\end{array}$ & & $\begin{array}{c}-0.99^{* * *} \\
(0.20)\end{array}$ & $\begin{array}{c}-0.98^{* * *} \\
(0.28)\end{array}$ \\
\hline Skilled w. & $\begin{array}{c}0.27 \\
(0.18)\end{array}$ & & $\begin{array}{c}0.26 \\
(0.18)\end{array}$ & $\begin{array}{c}0.30 \\
(0.21)\end{array}$ \\
\hline Medium edu & $\begin{array}{l}-0.03 \\
(0.11)\end{array}$ & & $\begin{array}{l}-0.03 \\
(0.11)\end{array}$ & $\begin{array}{l}-0.03 \\
(0.11)\end{array}$ \\
\hline Higher edu & $\begin{array}{l}-0.29^{*} \\
(0.12)\end{array}$ & & $\begin{array}{l}-0.28^{*} \\
(0.12)\end{array}$ & $\begin{array}{l}-0.29^{*} \\
(0.13)\end{array}$ \\
\hline Intermediate & & $\begin{array}{l}-0.09 \\
(0.11)\end{array}$ & $\begin{array}{l}-0.02 \\
(0.10)\end{array}$ & $\begin{array}{l}-0.01 \\
(0.10)\end{array}$ \\
\hline Cosmopolitan & & $\begin{array}{l}-0.21 \\
(0.13)\end{array}$ & $\begin{array}{l}-0.18 \\
(0.13)\end{array}$ & $\begin{array}{l}-0.17 \\
(0.13)\end{array}$ \\
\hline Offshorability & & $\begin{array}{l}-0.01 \\
(0.01)\end{array}$ & $\begin{array}{c}0.00 \\
(0.01)\end{array}$ & $\begin{array}{c}0.04 \\
(0.04)\end{array}$ \\
\hline $\begin{array}{l}\text { Hi. serv. \# } \\
\text { Offshorability }\end{array}$ & & & & $\begin{array}{l}-0.01 \\
(0.04)\end{array}$ \\
\hline $\begin{array}{l}\text { Lo. serv. \# } \\
\text { Offshorability }\end{array}$ & & & & -0.07 \\
\hline
\end{tabular}


Rout.nman \#

Offshorability

Petite b. \# Offshorability

Skilled w. \#

Offshorability

Female

$0.56^{* * *}$

$(0.09)$

$0.62^{* * *}$

$(0.09)$

$0.54^{* * *}$

Age

$\begin{array}{cccc}0.01^{*} & 0.01^{*} & 0.01^{*} & 0.01^{*} \\ (0.00) & (0.00) & (0.00) & (0.00)\end{array}$

\begin{tabular}{lcccc} 
Urban-rural & 0.00 & -0.01 & 0.01 & 0.01 \\
residence & $(0.02)$ & $(0.02)$ & $(0.02)$ & $(0.02)$ \\
& & & & $3.99^{* * *}$ \\
Constant & $3.97^{* * *}$ & $3.77^{* * *}$ & $(0.22)$ & $(0.23)$ \\
\hline Observations & $(0.22)$ & $(0.18)$ & 1149 & 1149 \\
$R^{2}$ & 1149 & 1149 & 0.114 & 0.118 \\
Adjusted $R^{2}$ & 0.112 & 0.061 & 0.104 & 0.104 \\
\hline Standard errors
\end{tabular}

Standard errors in parentheses

${ }^{*} p<0.05,{ }^{* *} p<0.01,{ }^{* * *} p<0.001$

Table A.5.1.5: Explaining Economic Attitudes in Switzerland

\begin{tabular}{|c|c|c|c|c|}
\hline & $\begin{array}{c}1 \\
\text { Class \& } \\
\text { education }\end{array}$ & $\begin{array}{c}2 \\
\text { Globalization } \\
\text { model }\end{array}$ & $\begin{array}{c}3 \\
\text { Combined } \\
\text { model }\end{array}$ & $\begin{array}{c}4 \\
\text { Interaction } \\
\text { model }\end{array}$ \\
\hline Hi. serv. & $\begin{array}{c}-0.77^{\text {**** }} \\
(0.21)\end{array}$ & & $\begin{array}{c}-0.80^{* * *} \\
(0.21)\end{array}$ & $\begin{array}{c}-0.89^{* * *} \\
(0.24)\end{array}$ \\
\hline Lo. serv. & $\begin{array}{l}-0.41^{*} \\
(0.18)\end{array}$ & & $\begin{array}{l}-0.44^{*} \\
(0.18)\end{array}$ & $\begin{array}{l}-0.49^{*} \\
(0.21)\end{array}$ \\
\hline Rout.nman & $\begin{array}{l}-0.30 \\
(0.17)\end{array}$ & & $\begin{array}{l}-0.31 \\
(0.17)\end{array}$ & $\begin{array}{l}-0.26 \\
(0.19)\end{array}$ \\
\hline Petite b. & $\begin{array}{l}-0.89^{* * *} \\
(0.29)\end{array}$ & & $\begin{array}{l}-0.86^{* * *} \\
(0.29)\end{array}$ & $\begin{array}{l}-0.35 \\
(0.32)\end{array}$ \\
\hline Skilled w. & $\begin{array}{c}0.08 \\
(0.20)\end{array}$ & & $\begin{array}{c}0.07 \\
(0.20)\end{array}$ & $\begin{array}{c}-0.04 \\
(0.23)\end{array}$ \\
\hline Medium edu & $\begin{array}{c}-0.57^{* * *} \\
(0.15)\end{array}$ & & $\begin{array}{c}-0.56^{* * *} \\
(0.15)\end{array}$ & $\begin{array}{c}-0.51^{\text {*** }} \\
(0.15)\end{array}$ \\
\hline Higher edu & $\begin{array}{c}-0.65^{* * *} \\
(0.19)\end{array}$ & & $\begin{array}{c}-0.66^{* * *} \\
(0.19)\end{array}$ & $\begin{array}{c}-0.59^{* *} \\
(0.19)\end{array}$ \\
\hline Intermediate & & $\begin{array}{c}0.12 \\
(0.11)\end{array}$ & $\begin{array}{c}0.20 \\
(0.11)\end{array}$ & $\begin{array}{c}0.22^{*} \\
(0.11)\end{array}$ \\
\hline Cosmopolitan & & $\begin{array}{c}0.22 \\
(0.14)\end{array}$ & $\begin{array}{c}0.27 \\
(0.14)\end{array}$ & $\begin{array}{c}0.30^{*} \\
(0.14)\end{array}$ \\
\hline
\end{tabular}


Offshorability

Hi. serv. \#

Offshorability

Lo. serv. \#

Offshorability

Rout.nman \#

Offshorability

Petite b. \# Offshorability

Skilled w. \#

Offshorability

\begin{tabular}{|c|c|c|c|c|}
\hline Female & $\begin{array}{l}0.27^{* *} \\
(0.10)\end{array}$ & $\begin{array}{l}0.33^{* * * *} \\
(0.10)\end{array}$ & $\begin{array}{l}0.27^{* *} \\
(0.10)\end{array}$ & $\begin{array}{l}0.27^{* *} \\
(0.10)\end{array}$ \\
\hline Age & $\begin{array}{l}-0.01^{* *} \\
(0.00)\end{array}$ & $\begin{array}{l}-0.01^{* *} \\
(0.00)\end{array}$ & $\begin{array}{l}-0.01^{*} \\
(0.00)\end{array}$ & $\begin{array}{l}-0.01^{*} \\
(0.00)\end{array}$ \\
\hline $\begin{array}{l}\text { Urban-rural } \\
\text { residence }\end{array}$ & $\begin{array}{l}0.14^{* * *} \\
(0.03)\end{array}$ & $\begin{array}{l}0.13^{* * * *} \\
(0.03)\end{array}$ & $\begin{array}{l}0.14^{* * * *} \\
(0.03)\end{array}$ & $\begin{array}{l}0.14^{* * *} \\
(0.03)\end{array}$ \\
\hline Constant & $\begin{array}{c}4.97^{* * *} \\
(0.25)\end{array}$ & $\begin{array}{l}4.06^{* * * *} \\
(0.16) \\
\end{array}$ & $\begin{array}{l}4.86^{* * * *} \\
(0.26)\end{array}$ & $\begin{array}{c}4.80^{* * *} \\
(0.27)\end{array}$ \\
\hline Observations & 980 & 980 & 980 & 980 \\
\hline$R^{2}$ & 0.121 & 0.059 & 0.127 & 0.136 \\
\hline Adjusted $R^{2}$ & 0.112 & 0.053 & 0.115 & 0.120 \\
\hline
\end{tabular}

Standard errors in parentheses

${ }^{*} p<0.05,{ }^{* *} p<0.01,{ }^{* * *} p<0.001$

Table A.5.1.6: Explaining Economic Attitudes in the UK

\begin{tabular}{|c|c|c|c|c|}
\hline & $\begin{array}{c}1 \\
\text { Class \& } \\
\text { education }\end{array}$ & $\begin{array}{c}2 \\
\begin{array}{c}\text { Globalization } \\
\text { model }\end{array} \\
\end{array}$ & $\begin{array}{c}3 \\
\text { Combined } \\
\text { model }\end{array}$ & $\begin{array}{c}4 \\
\text { Interaction } \\
\text { model } \\
\end{array}$ \\
\hline Hi. serv. & $\begin{array}{c}-0.44 \\
(0.29)\end{array}$ & & $\begin{array}{l}-0.40 \\
(0.29)\end{array}$ & $\begin{array}{c}-0.73^{*} \\
(0.32)\end{array}$ \\
\hline Lo. serv. & $\begin{array}{l}-0.27 \\
(0.27)\end{array}$ & & $\begin{array}{l}-0.23 \\
(0.28)\end{array}$ & $\begin{array}{l}-0.30 \\
(0.34)\end{array}$ \\
\hline Rout.nman & $\begin{array}{l}-0.13 \\
(0.25)\end{array}$ & & $\begin{array}{l}-0.17 \\
(0.26)\end{array}$ & $\begin{array}{l}-0.24 \\
(0.28)\end{array}$ \\
\hline Petite b. & $\begin{array}{l}-0.70^{*} \\
(0.35)\end{array}$ & & $\begin{array}{l}-0.72^{*} \\
(0.35)\end{array}$ & $\begin{array}{l}-0.68 \\
(0.46)\end{array}$ \\
\hline Skilled w. & $\begin{array}{l}-0.17 \\
(0.31)\end{array}$ & & $\begin{array}{l}-0.25 \\
(0.31)\end{array}$ & $\begin{array}{l}-0.19 \\
(0.35)\end{array}$ \\
\hline
\end{tabular}

$\begin{array}{ccc}-0.02 & -0.01 & 0.00 \\ (0.02) & (0.02) & (0.06)\end{array}$

0.02

$(0.07)$

0.00

(0.06)

$-0.05$

(0.07)

$-0.20^{*}$

(0.10)

0.04

(0.07)

$0.27^{* *}$

$-0.01^{*}$

$0.14^{* * *}$ 
Medium edu

Higher edu

Intermediate

Cosmopolitan

Offshorability

Hi. serv. \#

Offshorability

Lo. serv. \#

Offshorability

Rout.nman \#

Offshorability

Petite b. \# Offshorability

Skilled w. \#

Offshorability

Female

Age

Urban-rural

residence

Constant

Observation

$R^{2}$

Adjusted $R^{2}$
0.06

(0.18)

0.25

(0.20)

0.35

(0.19)

$0.66^{* *}$

(0.24)

$-0.05^{*}$

$(0.02)$

(0.02)

$(0.24)$

$-0.05^{*}$

0.35

$(0.19)$

$(0.20)$

$0.66^{* *}$

(0.24)

$-0.10$

(0.08)

0.14

(0.10)

0.05

(0.10)

0.04

(0.09)

$-0.01$

(0.12)

$-0.04$

(0.10)

0.11

0.20

0.15

0.15

(0.16)

(0.14)

(0.16)

(0.17)

$-0.00$

(0.00)

$-0.00$

(0.00)

$-0.00$

(0.00)

0.00

(0.00)

0.07

(0.03)

$0.07^{*}$

$0.07^{*}$

$0.07^{*}$

(0.03)

(0.03)

$3.75^{* * *}$

$3.45^{\text {*** }}$

$3.63^{* * * *}$

$3.63^{* * * *}$

(0.37)

578

0.025

0.008

(0.28)

(0.37) (0.39)

0.04

0.054

0.031

0.032

0.034

Table A.5.1.7: Explaining Economic Attitudes in Denmark

\begin{tabular}{lcccc}
\hline & $\begin{array}{c}1 \\
\text { Class \& } \\
\text { education }\end{array}$ & $\begin{array}{c}\text { Globalization } \\
\text { model }\end{array}$ & $\begin{array}{c}3 \\
\text { Combined } \\
\text { model }\end{array}$ & $\begin{array}{c}\text { Interaction } \\
\text { model }\end{array}$ \\
\hline Hi. serv. & $-0.77^{* * *}$ & & $-0.58^{* *}$ & $-0.63^{* *}$ \\
& $(0.18)$ & & $(0.18)$ & $(0.22)$ \\
Lo. serv. & 0.04 & & 0.35 \\
& $(0.17)$ & & 0.23 & $(0.21)$
\end{tabular}




\begin{tabular}{|c|c|c|c|c|}
\hline Rout.nman & $\begin{array}{c}0.06 \\
(0.17)\end{array}$ & & $\begin{array}{c}0.19 \\
(0.17)\end{array}$ & $\begin{array}{c}0.12 \\
(0.20)\end{array}$ \\
\hline Petite b. & $\begin{array}{c}-1.03^{* * *} \\
(0.24)\end{array}$ & & $\begin{array}{c}-0.88^{* * *} \\
(0.25)\end{array}$ & $\begin{array}{l}-0.99^{* *} \\
(0.38)\end{array}$ \\
\hline Skilled w. & $\begin{array}{l}-0.18 \\
(0.21)\end{array}$ & & $\begin{array}{c}-0.14 \\
(0.20)\end{array}$ & $\begin{array}{l}-0.17 \\
(0.23)\end{array}$ \\
\hline Medium edu & $\begin{array}{l}-0.22 \\
(0.14)\end{array}$ & & $\begin{array}{l}-0.21 \\
(0.14)\end{array}$ & $\begin{array}{l}-0.24 \\
(0.14)\end{array}$ \\
\hline Higher edu & $\begin{array}{c}0.08 \\
(0.15)\end{array}$ & & $\begin{array}{c}0.05 \\
(0.14)\end{array}$ & $\begin{array}{c}0.02 \\
(0.14)\end{array}$ \\
\hline Intermediate & & $\begin{array}{l}-0.11 \\
(0.13)\end{array}$ & $\begin{array}{l}-0.07 \\
(0.13)\end{array}$ & $\begin{array}{l}-0.05 \\
(0.14)\end{array}$ \\
\hline Cosmopolitan & & $\begin{array}{c}0.13 \\
(0.21)\end{array}$ & $\begin{array}{c}0.19 \\
(0.22)\end{array}$ & $\begin{array}{c}0.19 \\
(0.22)\end{array}$ \\
\hline Offshorability & & $\begin{array}{c}-0.09^{* * *} \\
(0.02)\end{array}$ & $\begin{array}{c}-0.09^{* * *} \\
(0.02)\end{array}$ & $\begin{array}{l}-0.11^{*} \\
(0.05)\end{array}$ \\
\hline $\begin{array}{l}\text { Hi. serv. \# } \\
\text { Offshorability }\end{array}$ & & & & $\begin{array}{c}0.03 \\
(0.06)\end{array}$ \\
\hline $\begin{array}{l}\text { Lo. serv. \# } \\
\text { Offshorability }\end{array}$ & & & & $\begin{array}{l}-0.02 \\
(0.06)\end{array}$ \\
\hline $\begin{array}{l}\text { Rout.nman \# } \\
\text { Offshorability }\end{array}$ & & & & $\begin{array}{l}0.05 \\
(0.06)\end{array}$ \\
\hline Petite b. \# Offshorability & & & & $\begin{array}{c}0.05 \\
(0.09)\end{array}$ \\
\hline $\begin{array}{l}\text { Skilled w. \# } \\
\text { Offshorability }\end{array}$ & & & & $\begin{array}{r}0.03 \\
(0.08)\end{array}$ \\
\hline Female & $\begin{array}{c}0.36^{* * *} \\
(0.11)\end{array}$ & $\begin{array}{c}0.54^{* * *} \\
(0.10)\end{array}$ & $\begin{array}{l}0.31^{* *} \\
(0.11)\end{array}$ & $\begin{array}{l}0.29^{* *} \\
(0.11)\end{array}$ \\
\hline Age & $\begin{array}{l}0.01^{*} \\
(0.00)\end{array}$ & $\begin{array}{l}0.01^{*} \\
(0.00)\end{array}$ & $\begin{array}{l}0.01^{\text {** }} \\
(0.00)\end{array}$ & $\begin{array}{l}0.01^{*} \\
(0.00)\end{array}$ \\
\hline $\begin{array}{l}\text { Urban-rural } \\
\text { residence }\end{array}$ & $\begin{array}{l}0.05^{*} \\
(0.02)\end{array}$ & $\begin{array}{l}0.06^{* *} \\
(0.02)\end{array}$ & $\begin{array}{l}0.05^{*} \\
(0.02)\end{array}$ & $\begin{array}{l}0.05^{*} \\
(0.02)\end{array}$ \\
\hline Constant & $\begin{array}{l}3.37^{* * *} \\
(0.24)\end{array}$ & $\begin{array}{l}3.22^{* * * *} \\
(0.18)\end{array}$ & $\begin{array}{c}3.42^{* * * *} \\
(0.24)\end{array}$ & $\begin{array}{l}3.48^{* * *} \\
(0.25)\end{array}$ \\
\hline $\begin{array}{l}\text { Observations } \\
R^{2} \\
\text { Adjusted } R^{2}\end{array}$ & $\begin{array}{c}993 \\
0.098 \\
0.089\end{array}$ & $\begin{array}{c}993 \\
0.074 \\
0.068\end{array}$ & $\begin{array}{c}993 \\
0.124 \\
0.112\end{array}$ & $\begin{array}{c}993 \\
0.127 \\
0.111\end{array}$ \\
\hline
\end{tabular}

Standard errors in parentheses

${ }^{*} p<0.05,{ }^{* *} p<0.01,{ }^{* * *} p<0.001$ 
Table A.5.1.8: Explaining Economic Attitudes in Norway

\begin{tabular}{|c|c|c|c|c|}
\hline & $\begin{array}{c}1 \\
\text { Class \& } \\
\text { education }\end{array}$ & $\begin{array}{c}2 \\
\text { Globalization } \\
\text { model }\end{array}$ & $\begin{array}{c}3 \\
\text { Combined } \\
\text { model }\end{array}$ & $\begin{array}{c}4 \\
\text { Interaction } \\
\text { model }\end{array}$ \\
\hline Hi. serv. & $\begin{array}{c}-1.17^{* * * *} \\
(0.24)\end{array}$ & & $\begin{array}{c}-1.19^{* * * *} \\
(0.24)\end{array}$ & $\begin{array}{c}-0.98^{* * *} \\
(0.27)\end{array}$ \\
\hline Lo. serv. & $\begin{array}{c}-0.79^{* * *} \\
(0.23)\end{array}$ & & $\begin{array}{c}-0.80^{* * *} \\
(0.24)\end{array}$ & $\begin{array}{l}-0.82^{* *} \\
(0.28)\end{array}$ \\
\hline Rout.nman & $\begin{array}{l}-0.22 \\
(0.22)\end{array}$ & & $\begin{array}{l}-0.23 \\
(0.22)\end{array}$ & $\begin{array}{l}-0.19 \\
(0.24)\end{array}$ \\
\hline Petite b. & $\begin{array}{c}-1.58^{* * *} \\
(0.29)\end{array}$ & & $\begin{array}{c}-1.58^{* * *} \\
(0.30)\end{array}$ & $\begin{array}{c}-1.45^{* * *} \\
(0.39)\end{array}$ \\
\hline Skilled w. & $\begin{array}{l}-0.44 \\
(0.27)\end{array}$ & & $\begin{array}{l}-0.46 \\
(0.27)\end{array}$ & $\begin{array}{l}-0.44 \\
(0.32)\end{array}$ \\
\hline Medium edu & $\begin{array}{l}-0.04 \\
(0.16)\end{array}$ & & $\begin{array}{l}-0.03 \\
(0.16)\end{array}$ & $\begin{array}{l}-0.05 \\
(0.16)\end{array}$ \\
\hline Higher edu & $\begin{array}{c}0.17 \\
(0.16)\end{array}$ & & $\begin{array}{c}0.16 \\
(0.16)\end{array}$ & $\begin{array}{c}0.14 \\
(0.16)\end{array}$ \\
\hline Intermediate & & $\begin{array}{c}0.04 \\
(0.19)\end{array}$ & $\begin{array}{c}0.03 \\
(0.19)\end{array}$ & $\begin{array}{c}0.04 \\
(0.19)\end{array}$ \\
\hline Cosmopolitan & & $\begin{array}{c}0.36 \\
(0.20)\end{array}$ & $\begin{array}{c}0.30 \\
(0.20)\end{array}$ & $\begin{array}{c}0.30 \\
(0.20)\end{array}$ \\
\hline Offshorability & & $\begin{array}{l}-0.02 \\
(0.02)\end{array}$ & $\begin{array}{c}0.01 \\
(0.02)\end{array}$ & $\begin{array}{c}0.09 \\
(0.09)\end{array}$ \\
\hline $\begin{array}{l}\text { Hi. serv. \# } \\
\text { Offshorability }\end{array}$ & & & & $\begin{array}{l}-0.13 \\
(0.10)\end{array}$ \\
\hline $\begin{array}{l}\text { Lo. serv. \# } \\
\text { Offshorability }\end{array}$ & & & & $\begin{array}{l}-0.06 \\
(0.10)\end{array}$ \\
\hline $\begin{array}{l}\text { Rout.nman \# } \\
\text { Offshorability }\end{array}$ & & & & $\begin{array}{l}-0.08 \\
(0.10)\end{array}$ \\
\hline Petite b. \# Offshorability & & & & $\begin{array}{l}-0.12 \\
(0.12)\end{array}$ \\
\hline $\begin{array}{l}\text { Skilled w. \# } \\
\text { Offshorability }\end{array}$ & & & & $\begin{array}{l}-0.07 \\
(0.11)\end{array}$ \\
\hline Female & $\begin{array}{l}0.47^{* * *} \\
(0.13)\end{array}$ & $\begin{array}{c}0.66^{* * *} \\
(0.12)\end{array}$ & $\begin{array}{l}0.48^{* * * *} \\
(0.13)\end{array}$ & $\begin{array}{l}0.49^{* * * *} \\
(0.13)\end{array}$ \\
\hline Age & $\begin{array}{l}-0.00 \\
(0.00)\end{array}$ & $\begin{array}{l}-0.01 \\
(0.00)\end{array}$ & $\begin{array}{l}-0.00 \\
(0.00)\end{array}$ & $\begin{array}{l}-0.00 \\
(0.00)\end{array}$ \\
\hline
\end{tabular}




\begin{tabular}{lcccc}
$\begin{array}{l}\text { Urban-rural } \\
\text { residence }\end{array}$ & 0.02 & -0.01 & 0.02 & 0.02 \\
& $(0.03)$ & $(0.03)$ & $(0.03)$ & $(0.03)$ \\
Constant & $4.20^{* * * *}$ & $3.84^{* * *}$ & $4.17^{* * *}$ & $4.10^{* * * *}$ \\
& $(0.26)$ & $(0.23)$ & $(0.26)$ & $(0.27)$ \\
\hline Observations & 723 & 723 & 723 & 723 \\
$R^{2}$ & 0.122 & 0.050 & 0.126 & 0.130 \\
Adjusted $R^{2}$ & 0.110 & 0.042 & 0.110 & 0.107 \\
\hline
\end{tabular}

Standard errors in parentheses

${ }^{*} p<0.05,{ }^{* *} p<0.01,{ }^{* * *} p<0.001$

Table A.5.1.9: Explaining Economic Attitudes in Sweden

\begin{tabular}{|c|c|c|c|c|}
\hline & $\begin{array}{c}1 \\
\text { Class \& } \\
\text { education }\end{array}$ & $\begin{array}{c}2 \\
\begin{array}{c}\text { Globalization } \\
\text { model }\end{array}\end{array}$ & $\begin{array}{c}3 \\
\text { Combined } \\
\text { model }\end{array}$ & $\begin{array}{c}4 \\
\text { Interaction } \\
\text { model }\end{array}$ \\
\hline Hi. serv. & $\begin{array}{c}-1.24^{* * * *} \\
(0.28)\end{array}$ & & $\begin{array}{c}-1.17^{* * *} \\
(0.28)\end{array}$ & $\begin{array}{c}-1.43^{* * * *} \\
(0.33)\end{array}$ \\
\hline Lo. serv. & $\begin{array}{c}-0.90^{* * *} \\
(0.25)\end{array}$ & & $\begin{array}{c}-0.84^{* * *} \\
(0.25)\end{array}$ & $\begin{array}{c}-0.92^{* *} \\
(0.29)\end{array}$ \\
\hline Rout.nman & $\begin{array}{l}-0.33 \\
(0.24)\end{array}$ & & $\begin{array}{l}-0.30 \\
(0.24)\end{array}$ & $\begin{array}{l}-0.49 \\
(0.26)\end{array}$ \\
\hline Petite b. & $\begin{array}{c}-1.88^{* * *} \\
(0.32)\end{array}$ & & $\begin{array}{c}-1.86^{* * *} \\
(0.32)\end{array}$ & $\begin{array}{c}-2.16^{* * *} \\
(0.36)\end{array}$ \\
\hline Skilled w. & $\begin{array}{l}-0.11 \\
(0.30)\end{array}$ & & $\begin{array}{l}-0.11 \\
(0.30)\end{array}$ & $\begin{array}{l}-0.39 \\
(0.32)\end{array}$ \\
\hline Medium edu & $\begin{array}{l}-0.37 \\
(0.20)\end{array}$ & & $\begin{array}{l}-0.36 \\
(0.20)\end{array}$ & $\begin{array}{l}-0.39 \\
(0.20)\end{array}$ \\
\hline Higher edu & $\begin{array}{l}-0.18 \\
(0.22)\end{array}$ & & $\begin{array}{l}-0.19 \\
(0.22)\end{array}$ & $\begin{array}{l}-0.24 \\
(0.22)\end{array}$ \\
\hline Intermediate & & $\begin{array}{l}-0.09 \\
(0.16)\end{array}$ & $\begin{array}{l}-0.06 \\
(0.15)\end{array}$ & $\begin{array}{l}-0.06 \\
(0.15)\end{array}$ \\
\hline Cosmopolitan & & $\begin{array}{c}0.29 \\
(0.24)\end{array}$ & $\begin{array}{c}0.11 \\
(0.24)\end{array}$ & $\begin{array}{c}0.11 \\
(0.24)\end{array}$ \\
\hline Offshorability & & $\begin{array}{l}-0.04^{*} \\
(0.02)\end{array}$ & $\begin{array}{l}-0.02 \\
(0.02)\end{array}$ & $\begin{array}{l}-0.13^{*} \\
(0.06)\end{array}$ \\
\hline $\begin{array}{l}\text { Hi. serv. \# } \\
\text { Offshorability }\end{array}$ & & & & $\begin{array}{l}0.14 \\
(0.08)\end{array}$ \\
\hline $\begin{array}{l}\text { Lo. serv. \# } \\
\text { Offshorability }\end{array}$ & & & & $\begin{array}{l}0.08 \\
(0.07)\end{array}$ \\
\hline $\begin{array}{l}\text { Rout.nman \# } \\
\text { Offshorability }\end{array}$ & & & & $\begin{array}{l}0.12 \\
(0.07)\end{array}$ \\
\hline
\end{tabular}


Petite b. \# Offshorability

Skilled w. \#

Offshorability

\begin{tabular}{lcccc} 
Female & $0.45^{* * *}$ & $0.49^{* * *}$ & $0.44^{* *}$ & $0.45^{* *}$ \\
& $(0.14)$ & $(0.13)$ & $(0.14)$ & $(0.14)$ \\
Age & & & 0.01 & 0.01 \\
& $(0.01$ & 0.01 & $(0.00)$ & $(0.00)$ \\
Urban-rural & & $(0.00)$ & 0.04 & 0.04 \\
residence & 0.04 & -0.00 & $(0.03)$ & $(0.03)$ \\
Constant & $(0.03)$ & $(0.03)$ & & \\
& & & $4.25^{* * *}$ & $4.43^{* * *}$ \\
\hline Observations & $4.24^{* * *}$ & $3.63^{* * *}$ & $(0.38)$ & $(0.40)$ \\
$R^{2}$ & $(0.38)$ & $(0.30)$ & 753 & 753 \\
Adjusted $R^{2}$ & 753 & 753 & 0.106 & 0.112 \\
\hline
\end{tabular}

\section{A.5.2: Country specific analyses of EU attitudes}

Table A.5.2.1: Explaining EU Attitudes in Austria

\begin{tabular}{|c|c|c|c|c|}
\hline & $\begin{array}{c}1 \\
\text { Class \& } \\
\text { education }\end{array}$ & $\begin{array}{c}2 \\
\text { Globalization } \\
\text { model }\end{array}$ & $\begin{array}{c}3 \\
\text { Combined } \\
\text { model }\end{array}$ & $\begin{array}{c}4 \\
\text { Interaction } \\
\text { model }\end{array}$ \\
\hline Hi. serv. & $\begin{array}{l}-0.64 \\
(0.39)\end{array}$ & & $\begin{array}{l}-0.39 \\
(0.37)\end{array}$ & $\begin{array}{l}-0.31 \\
(0.40)\end{array}$ \\
\hline Lo. serv. & $\begin{array}{l}-0.53 \\
(0.32)\end{array}$ & & $\begin{array}{l}-0.22 \\
(0.32)\end{array}$ & $\begin{array}{l}-0.17 \\
(0.35)\end{array}$ \\
\hline Rout.nman & $\begin{array}{l}-0.84^{* * *} \\
(0.31)\end{array}$ & & $\begin{array}{l}-0.59 \\
(0.30)\end{array}$ & $\begin{array}{l}-0.63 \\
(0.32)\end{array}$ \\
\hline Petite b. & $\begin{array}{l}-0.44 \\
(0.41)\end{array}$ & & $\begin{array}{l}-0.23 \\
(0.39)\end{array}$ & $\begin{array}{l}-0.64 \\
(0.49)\end{array}$ \\
\hline Skilled w. & $\begin{array}{l}-0.17 \\
(0.36)\end{array}$ & & $\begin{array}{l}-0.28 \\
(0.35)\end{array}$ & $\begin{array}{l}-0.29 \\
(0.37)\end{array}$ \\
\hline Medium edu & $\begin{array}{l}-0.38 \\
(0.27)\end{array}$ & & $\begin{array}{l}-0.48 \\
(0.27)\end{array}$ & $\begin{array}{l}-0.53 \\
(0.27)\end{array}$ \\
\hline Higher edu & $\begin{array}{c}-2.26^{\text {*** }} \\
(0.41)\end{array}$ & & $\begin{array}{c}-1.96^{* * *} \\
(0.40)\end{array}$ & $\begin{array}{c}-2.03^{\text {*** }} \\
(0.40)\end{array}$ \\
\hline Intermediate & & $\begin{array}{c}-1.37^{* * *} \\
(0.26)\end{array}$ & $\begin{array}{c}-1.17^{\text {*** }} \\
(0.25)\end{array}$ & $\begin{array}{c}-1.16^{* * *} \\
(0.26)\end{array}$ \\
\hline Cosmopolitan & & $\begin{array}{c}-2.37^{* * * *} \\
(0.27)\end{array}$ & $\begin{array}{c}-2.14^{* * * *} \\
(0.26)\end{array}$ & $\begin{array}{c}-2.12^{* * * *} \\
(0.27)\end{array}$ \\
\hline
\end{tabular}


Offshorability

Hi. serv. \#

Offshorability

Lo. serv. \#

Offshorability

Rout.nman \#

Offshorability

Petite b. \# Offshorability

Skilled w. \#

Offshorability

\begin{tabular}{lcccc} 
Female & $0.71^{* * *}$ & $0.50^{* *}$ & $0.54^{* *}$ & $0.55^{* *}$ \\
& $(0.19)$ & $(0.17)$ & $(0.18)$ & $(0.18)$ \\
Age & 0.01 & -0.00 & -0.01 & -0.01 \\
& $(0.01)$ & $(0.01)$ & $(0.01)$ & $(0.01)$ \\
Urban-rural & & & -0.03 \\
residence & $-0.07^{*}$ & -0.04 & $(0.03)$ & $(0.03)$ \\
Constant & $(0.03)$ & $(0.03)$ & & $7.43^{* * *}$ \\
& & & & $(0.43)$ \\
\hline Observations & $6.40^{* * * *}$ & $6.47^{* * *}$ & $(0.43)$ & 924 \\
$R^{2}$ & $(0.42)$ & $(0.33)$ & 924 & 0.173 \\
Adjusted $R^{2}$ & 924 & 924 & 0.171 & 0.157 \\
\hline
\end{tabular}

Standard errors in parentheses

${ }^{*} p<0.05,{ }^{* *} p<0.01,{ }^{* * *} p<0.001$

$\begin{array}{lll}-0.07^{*} & -0.06 & -0.25 \\ (0.03) & (0.03) & (0.32)\end{array}$

0.13

$(0.33)$

0.18

$(0.32)$

0.21

$(0.32)$

0.30

(0.34)

0.20

$(0.33)$

$0.55^{* *}$

$-0.01$

$7.43^{* * *}$ 924

0.157

Table A.5.2.2: Explaining EU Attitudes in France

\begin{tabular}{|c|c|c|c|c|}
\hline & $\begin{array}{c}1 \\
\text { Class \& } \\
\text { education }\end{array}$ & $\begin{array}{c}2 \\
\begin{array}{c}\text { Globalization } \\
\text { model }\end{array}\end{array}$ & $\begin{array}{c}3 \\
\text { Combined } \\
\text { model }\end{array}$ & $\begin{array}{c}4 \\
\text { Interaction } \\
\text { model }\end{array}$ \\
\hline Hi. serv. & $\begin{array}{c}-0.89^{* *} \\
(0.29)\end{array}$ & & $\begin{array}{c}-0.86^{* *} \\
(0.30)\end{array}$ & $\begin{array}{c}-0.64 \\
(0.38)\end{array}$ \\
\hline Lo. serv. & $\begin{array}{l}-0.42 \\
(0.24)\end{array}$ & & $\begin{array}{l}-0.36 \\
(0.24)\end{array}$ & $\begin{array}{l}-0.67^{*} \\
(0.31)\end{array}$ \\
\hline Rout.nman & $\begin{array}{l}-0.67^{* *} \\
(0.24)\end{array}$ & & $\begin{array}{l}-0.65^{* *} \\
(0.24)\end{array}$ & $\begin{array}{c}-0.80^{* *} \\
(0.31)\end{array}$ \\
\hline Petite b. & $\begin{array}{l}-0.51 \\
(0.33)\end{array}$ & & $\begin{array}{l}-0.50 \\
(0.32)\end{array}$ & $\begin{array}{l}-0.44 \\
(0.55)\end{array}$ \\
\hline Skilled w. & $\begin{array}{c}0.21 \\
(0.26)\end{array}$ & & $\begin{array}{c}0.21 \\
(0.25)\end{array}$ & $\begin{array}{c}0.14 \\
(0.31)\end{array}$ \\
\hline
\end{tabular}


Medium edu

Higher edu

Intermediate

Cosmopolitan

Offshorability

Hi. serv. \#

Offshorability

Lo. serv. \#

Offshorability

Rout.nman \#

Offshorability

Petite b. \# Offshorability

Skilled w. \#

Offshorability

Female

Age

Urban-rural

residence

Constant

Observations

$R^{2}$

Adjusted $R^{2}$

Standard errors in parentheses

${ }^{*} p<0.05,{ }^{* *} p<0.01,{ }^{* * *} p<0.001$

Table A.5.2.3: Explaining EU Attitudes in Germany

\begin{tabular}{lcccc} 
& $\begin{array}{c}\text { 1 } \\
\text { Class \& } \\
\text { education }\end{array}$ & $\begin{array}{c}\text { Globalization } \\
\text { model }\end{array}$ & $\begin{array}{c}\text { Combined } \\
\text { model }\end{array}$ & $\begin{array}{c}\text { Interaction } \\
\text { model }\end{array}$ \\
\hline Hi. serv. & $-0.98^{*}$ & & -0.74 & -0.44 \\
& $(0.43)$ & & $(0.41)$ & $(0.47)$ \\
Lo. serv. & $-0.96^{* *}$ & & $-0.85^{* *}$ & $-1.02^{* *}$
\end{tabular}

$\begin{array}{ll}-0.34 & -0.33\end{array}$

$(0.21)$

$(0.21)$

$-1.88^{* * * *}$

$-1.69^{* * *}$

$-1.66^{* * *}$

(0.27)

(0.27)

$-0.95^{* * *}$

$-0.60^{* *}$

$-0.63^{* *}$

$(0.21)$

$(0.20)$

(0.20)

$-1.60^{* * *}$

$-1.26^{* * *}$

$-1.29^{* * *}$

$(0.20)$

$(0.19)$

(0.19)

$-0.04$

(0.02)

0.00

$-0.05$

(0.02)

(0.05)

$-0.03$

$(0.07)$

0.11

$(0.07)$

0.07

$(0.07)$

0.02

(0.12)

0.05

(0.08)

$0.46^{* *}$

0.26

$0.43^{* *}$

$0.45^{\text {** }}$

(0.16)

(0.15)

(0.15)

(0.16)

$-0.01^{* *}$

$-0.00$

$-0.01^{* *}$

$-0.01^{* *}$

(0.00)

(0.00)

$-0.06^{*}$

$-0.06^{*}$

$-0.03$

$-0.03$

(0.03)

(0.03)

(0.03)

$8.02^{* * *}$

$7.13^{* * * *}$

$8.27^{* * *}$

$8.34^{* * *}$

(0.27)

(0.37)

(0.38)

1103

0.086

0.194

0.153

0.081

0.190

0.181

0.180

.




\begin{tabular}{|c|c|c|c|c|}
\hline & $(0.30)$ & & $(0.30)$ & $(0.38)$ \\
\hline Rout.nman & $\begin{array}{c}-0.32 \\
(0.31)\end{array}$ & & $\begin{array}{l}-0.46 \\
(0.32)\end{array}$ & $\begin{array}{c}-0.61 \\
(0.35)\end{array}$ \\
\hline Petite $b$. & $\begin{array}{l}-0.78 \\
(0.50)\end{array}$ & & $\begin{array}{l}-0.79 \\
(0.51)\end{array}$ & $\begin{array}{c}-2.09^{* * * *} \\
(0.60)\end{array}$ \\
\hline Skilled w. & $\begin{array}{c}0.05 \\
(0.32)\end{array}$ & & $\begin{array}{c}-0.06 \\
(0.32)\end{array}$ & $\begin{array}{c}-0.14 \\
(0.36)\end{array}$ \\
\hline Medium edu & $\begin{array}{l}-0.21 \\
(0.27)\end{array}$ & & $\begin{array}{l}-0.38 \\
(0.29)\end{array}$ & $\begin{array}{l}-0.44 \\
(0.29)\end{array}$ \\
\hline Higher edu & $\begin{array}{l}-1.02^{* *} \\
(0.35)\end{array}$ & & $\begin{array}{c}-1.18^{* * * *} \\
(0.35)\end{array}$ & $\begin{array}{r}-1.21^{* * * *} \\
(0.35)\end{array}$ \\
\hline Intermediate & & $\begin{array}{l}-0.91^{* *} \\
(0.28)\end{array}$ & $\begin{array}{c}-0.79^{* *} \\
(0.27)\end{array}$ & $\begin{array}{c}-0.85^{* *} \\
(0.27)\end{array}$ \\
\hline Cosmopolitan & & $\begin{array}{c}-1.62^{* * *} \\
(0.27)\end{array}$ & $\begin{array}{c}-1.51^{* * *} \\
(0.26)\end{array}$ & $\begin{array}{c}-1.58^{* * * *} \\
(0.26)\end{array}$ \\
\hline Offshorability & & $\begin{array}{l}-0.03 \\
(0.03)\end{array}$ & $\begin{array}{l}-0.02 \\
(0.03)\end{array}$ & $\begin{array}{l}-0.07 \\
(0.07)\end{array}$ \\
\hline $\begin{array}{l}\text { Hi. serv. \# } \\
\text { Offshorability }\end{array}$ & & & & $\begin{array}{l}-0.11 \\
(0.11)\end{array}$ \\
\hline $\begin{array}{l}\text { Lo. serv. \# } \\
\text { Offshorability }\end{array}$ & & & & $\begin{array}{c}0.09 \\
(0.09)\end{array}$ \\
\hline $\begin{array}{l}\text { Rout.nman \# } \\
\text { Offshorability }\end{array}$ & & & & $\begin{array}{c}0.09 \\
(0.11)\end{array}$ \\
\hline Petite b. \# Offshorability & & & & $\begin{array}{c}0.38^{*} \\
(0.16)\end{array}$ \\
\hline $\begin{array}{l}\text { Skilled w. \# } \\
\text { Offshorability }\end{array}$ & & & & $\begin{array}{c}0.05 \\
(0.11)\end{array}$ \\
\hline Female & $\begin{array}{c}0.02 \\
(0.24)\end{array}$ & $\begin{array}{c}0.01 \\
(0.20)\end{array}$ & $\begin{array}{c}0.03 \\
(0.23)\end{array}$ & $\begin{array}{c}0.02 \\
(0.23)\end{array}$ \\
\hline Age & $\begin{array}{l}-0.01 \\
(0.01)\end{array}$ & $\begin{array}{l}-0.01 \\
(0.01)\end{array}$ & $\begin{array}{l}-0.01 \\
(0.01)\end{array}$ & $\begin{array}{l}-0.01 \\
(0.01)\end{array}$ \\
\hline $\begin{array}{l}\text { Urban-rural } \\
\text { residence }\end{array}$ & $\begin{array}{c}-0.09 \\
(0.05)\end{array}$ & $\begin{array}{l}-0.06 \\
(0.05)\end{array}$ & $\begin{array}{l}-0.06 \\
(0.05)\end{array}$ & $\begin{array}{c}-0.05 \\
(0.05)\end{array}$ \\
\hline Constant & $\begin{array}{l}7.45^{* * *} \\
(0.52)\end{array}$ & $\begin{array}{l}7.39^{* * * *} \\
(0.39)\end{array}$ & $\begin{array}{c}8.13^{* * *} \\
(0.53)\end{array}$ & $\begin{array}{c}8.31^{* * * *} \\
(0.53)\end{array}$ \\
\hline $\begin{array}{l}\text { Observations } \\
R^{2} \\
\text { Adjusted } R^{2}\end{array}$ & $\begin{array}{c}798 \\
0.089 \\
0.077\end{array}$ & $\begin{array}{c}798 \\
0.083 \\
0.076\end{array}$ & $\begin{array}{c}798 \\
0.147 \\
0.133\end{array}$ & $\begin{array}{c}798 \\
0.160 \\
0.141\end{array}$ \\
\hline
\end{tabular}

Standard errors in parentheses 
${ }^{*} p<0.05,{ }^{* *} p<0.01,{ }^{* * *} p<0.001$

Table A.5.2.4: Explaining EU Attitudes in the Netherlands

\begin{tabular}{|c|c|c|c|c|}
\hline & $\begin{array}{c}1 \\
\text { Class \& } \\
\text { education }\end{array}$ & $\begin{array}{c}2 \\
\text { Globalization } \\
\text { model }\end{array}$ & $\begin{array}{c}3 \\
\text { Combined } \\
\text { model }\end{array}$ & $\begin{array}{c}4 \\
\text { Interaction } \\
\text { model }\end{array}$ \\
\hline Hi. serv. & $\begin{array}{l}-0.52 \\
(0.28)\end{array}$ & & $\begin{array}{l}-0.50 \\
(0.27)\end{array}$ & $\begin{array}{l}-0.61 \\
(0.32)\end{array}$ \\
\hline Lo. serv. & $\begin{array}{c}-0.40 \\
(0.27)\end{array}$ & & $\begin{array}{l}-0.34 \\
(0.27)\end{array}$ & $\begin{array}{l}-0.33 \\
(0.31)\end{array}$ \\
\hline Rout.nman & $\begin{array}{c}0.00 \\
(0.27)\end{array}$ & & $\begin{array}{c}0.04 \\
(0.26)\end{array}$ & $\begin{array}{l}-0.15 \\
(0.31)\end{array}$ \\
\hline Petite $b$. & $\begin{array}{l}-0.56 \\
(0.33)\end{array}$ & & $\begin{array}{l}-0.57 \\
(0.33)\end{array}$ & $\begin{array}{l}-0.24 \\
(0.42)\end{array}$ \\
\hline Skilled w. & $\begin{array}{c}0.27 \\
(0.35)\end{array}$ & & $\begin{array}{c}0.14 \\
(0.35)\end{array}$ & $\begin{array}{c}0.11 \\
(0.40)\end{array}$ \\
\hline Medium edu & $\begin{array}{l}-0.50^{* *} \\
(0.19)\end{array}$ & & $\begin{array}{l}-0.46^{*} \\
(0.19)\end{array}$ & $\begin{array}{l}-0.48^{*} \\
(0.19)\end{array}$ \\
\hline Higher edu & $\begin{array}{c}-1.43^{* * *} \\
(0.18)\end{array}$ & & $\begin{array}{c}-1.33^{* * *} \\
(0.18)\end{array}$ & $\begin{array}{l}-1.36^{* * *} \\
(0.18)\end{array}$ \\
\hline Intermediate & & $\begin{array}{c}-1.03^{* * *} \\
(0.16)\end{array}$ & $\begin{array}{c}-0.84^{* * *} \\
(0.16)\end{array}$ & $\begin{array}{c}-0.85^{* * *} \\
(0.16)\end{array}$ \\
\hline Cosmopolitan & & $\begin{array}{c}-0.92^{* * *} \\
(0.21)\end{array}$ & $\begin{array}{c}-0.72^{* * *} \\
(0.19)\end{array}$ & $\begin{array}{l}-0.72^{* * *} \\
(0.19)\end{array}$ \\
\hline Offshorability & & $\begin{array}{c}-0.03 \\
(0.02)\end{array}$ & $\begin{array}{l}-0.01 \\
(0.02)\end{array}$ & $\begin{array}{l}-0.06 \\
(0.08)\end{array}$ \\
\hline $\begin{array}{l}\text { Hi. serv. \# } \\
\text { Offshorability }\end{array}$ & & & & $\begin{array}{l}0.07 \\
(0.09)\end{array}$ \\
\hline $\begin{array}{l}\text { Lo. serv. \# } \\
\text { Offshorability }\end{array}$ & & & & $\begin{array}{l}0.03 \\
(0.09)\end{array}$ \\
\hline $\begin{array}{l}\text { Rout.nman \# } \\
\text { Offshorability }\end{array}$ & & & & $\begin{array}{l}0.11 \\
(0.10)\end{array}$ \\
\hline Petite b. \# Offshorability & & & & $\begin{array}{l}-0.05 \\
(0.11)\end{array}$ \\
\hline $\begin{array}{l}\text { Skilled w. \# } \\
\text { Offshorability }\end{array}$ & & & & $\begin{array}{l}0.03 \\
(0.11)\end{array}$ \\
\hline Female & $\begin{array}{l}0.36^{* *} \\
(0.13)\end{array}$ & $\begin{array}{l}0.40^{* *} \\
(0.14)\end{array}$ & $\begin{array}{l}0.30^{*} \\
(0.14)\end{array}$ & $\begin{array}{l}0.30^{*} \\
(0.14)\end{array}$ \\
\hline Age & -0.00 & 0.01 & 0.00 & 0.00 \\
\hline
\end{tabular}




\begin{tabular}{lcccc} 
& $(0.00)$ & $(0.00)$ & $(0.00)$ & $(0.00)$ \\
Urban-rural & & & & \\
residence & 0.04 & -0.00 & 0.05 & 0.05 \\
& $(0.04)$ & $(0.04)$ & $(0.04)$ & $(0.04)$ \\
Constant & & & & \\
& $5.50^{* * *}$ & $4.87^{* * *}$ & $5.67^{* * *}$ & $5.73^{* * *}$ \\
\hline Observations & $(0.37)$ & $(0.27)$ & $(0.37)$ & $(0.39)$ \\
$R^{2}$ & 1099 & 1099 & 1099 & 1099 \\
Adjusted $R^{2}$ & 0.141 & 0.067 & 0.173 & 0.176 \\
\hline Standard erors & 0.133 & 0.062 & 0.163 & 0.163 \\
\hline
\end{tabular}

Standard errors in parentheses

${ }^{*} p<0.05,{ }^{* *} p<0.01,{ }^{* * *} p<0.001$

Table A.5.2.5: Explaining EU Attitudes in Switzerland

\begin{tabular}{|c|c|c|c|c|}
\hline & $\begin{array}{c}1 \\
\text { Class \& } \\
\text { education }\end{array}$ & $\begin{array}{c}2 \\
\begin{array}{c}\text { Globalization } \\
\text { model }\end{array} \\
\end{array}$ & $\begin{array}{c}3 \\
\text { Combined } \\
\text { model }\end{array}$ & $\begin{array}{c}4 \\
\text { Interaction } \\
\text { model } \\
\end{array}$ \\
\hline Hi. serv. & $\begin{array}{l}-0.77^{*} \\
(0.39)\end{array}$ & & $\begin{array}{l}-0.58 \\
(0.40)\end{array}$ & $\begin{array}{l}-0.40 \\
(0.44)\end{array}$ \\
\hline Lo. serv. & $\begin{array}{c}-0.88^{* *} \\
(0.34)\end{array}$ & & $\begin{array}{l}-0.66 \\
(0.35)\end{array}$ & $\begin{array}{l}-0.31 \\
(0.38)\end{array}$ \\
\hline Rout.nman & $\begin{array}{l}-0.48 \\
(0.35)\end{array}$ & & $\begin{array}{l}-0.39 \\
(0.35)\end{array}$ & $\begin{array}{l}-0.18 \\
(0.37)\end{array}$ \\
\hline Petite b. & $\begin{array}{c}-0.04 \\
(0.58)\end{array}$ & & $\begin{array}{c}0.03 \\
(0.57)\end{array}$ & $\begin{array}{c}0.18 \\
(0.76)\end{array}$ \\
\hline Skilled w. & $\begin{array}{c}-0.09 \\
(0.37)\end{array}$ & & $\begin{array}{c}-0.01 \\
(0.37)\end{array}$ & $\begin{array}{c}0.39 \\
(0.40)\end{array}$ \\
\hline Medium edu & $\begin{array}{l}-0.53^{*} \\
(0.27)\end{array}$ & & $\begin{array}{l}-0.64^{*} \\
(0.26)\end{array}$ & $\begin{array}{l}-0.68^{* *} \\
(0.26)\end{array}$ \\
\hline Higher edu & $\begin{array}{c}-1.22^{* * * *} \\
(0.32)\end{array}$ & & $\begin{array}{c}-1.22^{* * * *} \\
(0.31)\end{array}$ & $\begin{array}{c}-1.27^{* * * *} \\
(0.32)\end{array}$ \\
\hline Intermediate & & $\begin{array}{c}-1.00^{* * * *} \\
(0.20)\end{array}$ & $\begin{array}{c}-0.83^{* * *} \\
(0.20)\end{array}$ & $\begin{array}{c}-0.82^{* * * *} \\
(0.20)\end{array}$ \\
\hline Cosmopolitan & & $\begin{array}{l}-1.41^{* * * *} \\
(0.24)\end{array}$ & $\begin{array}{c}-1.30^{* * *} \\
(0.24)\end{array}$ & $\begin{array}{c}-1.33^{* * *} \\
(0.24)\end{array}$ \\
\hline Offshorability & & $\begin{array}{c}-0.03 \\
(0.03)\end{array}$ & $\begin{array}{c}-0.01 \\
(0.03)\end{array}$ & $\begin{array}{l}0.37^{* * *} \\
(0.14)\end{array}$ \\
\hline $\begin{array}{l}\text { Hi. serv. \# } \\
\text { Offshorability }\end{array}$ & & & & $\begin{array}{l}-0.36^{*} \\
(0.15)\end{array}$ \\
\hline $\begin{array}{l}\text { Lo. serv. \# } \\
\text { Offshorability }\end{array}$ & & & & $\begin{array}{l}-0.42^{* *} \\
(0.14)\end{array}$ \\
\hline $\begin{array}{l}\text { Rout.nman \# } \\
\text { Offshorability }\end{array}$ & & & & $\begin{array}{l}-0.35^{*} \\
(0.16)\end{array}$ \\
\hline
\end{tabular}


Petite b. \# Offshorability

Skilled w. \#

Offshorability

\begin{tabular}{lcccc} 
Female & 0.22 & 0.30 & 0.24 & 0.22 \\
& $(0.19)$ & $(0.17)$ & $(0.19)$ & $(0.19)$ \\
Age & 0.01 & 0.01 & 0.01 & 0.01 \\
& $(0.01)$ & $(0.01)$ & $(0.01)$ & $(0.01)$ \\
Urban-rural & & & $-0.10^{*}$ & $-0.10^{*}$ \\
residence & $-0.12^{*}$ & $-0.13^{* *}$ & $(0.05)$ & $(0.05)$ \\
& $(0.05)$ & $(0.05)$ & & $6.32^{* * *}$ \\
Constant & & & $6.52^{* * *}$ & $(0.47)$ \\
\hline Observations & $5.98^{* * *}$ & $5.44^{* * *}$ & $(0.45)$ & 864 \\
$R^{2}$ & $(0.45)$ & $(0.31)$ & 864 & 0.119 \\
Adjusted $R^{2}$ & 864 & 864 & 0.112 & 0.100 \\
\hline
\end{tabular}

Standard errors in parentheses

${ }^{*} p<0.05,{ }^{* *} p<0.01,{ }^{* * *} p<0.001$

Table A.5.2.6: Explaining EU Attitudes in the UK

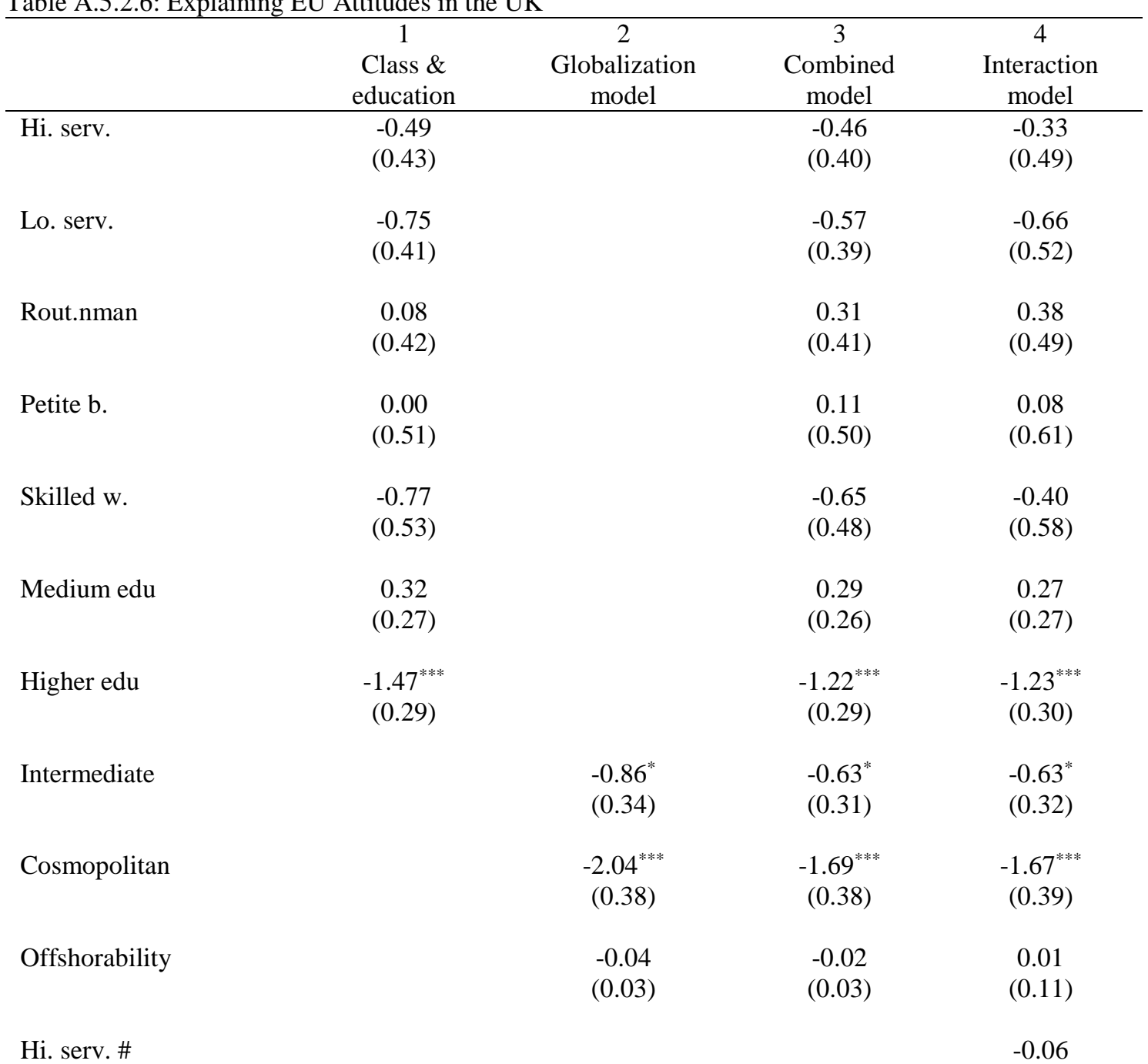


Offshorability

Lo. serv. \#

0.00

Offshorability

Rout.nman \#

$-0.04$

Offshorability

Petite b. \# Offshorability

Skilled w. \#

Offshorability

Female

0.43

0.27

0.28

(0.23)

(0.22)

(0.23)

(0.23)

Age

0.01

0.00

0.01

0.01

$(0.01)$

(0.01)

$(0.01)$

(0.01)

\begin{tabular}{lcccc} 
Urban-rural & $-0.13^{*}$ & $-0.13^{*}$ & $-0.11^{*}$ & $-0.12^{*}$ \\
residence & $(0.05)$ & $(0.06)$ & $(0.05)$ & $(0.05)$ \\
& & & & $7.67^{* * *}$ \\
Constant & $7.34^{* * *}$ & $7.40^{* * *}$ & $7.76^{* * *}$ & $(0.58)$ \\
\hline Observations & $(0.56)$ & $(0.45)$ & $(0.53)$ & 527 \\
$R^{2}$ & 527 & 527 & 527 & 0.202 \\
Adjusted $R^{2}$ & 0.152 & 0.108 & 0.199 & 0.174 \\
\hline
\end{tabular}

Standard errors in parentheses

${ }^{*} p<0.05,{ }^{* *} p<0.01,{ }^{* * *} p<0.001$

Table A.5.2.7: Explaining EU Attitudes in Denmark

\begin{tabular}{|c|c|c|c|c|}
\hline & $\begin{array}{c}1 \\
\text { Class \& } \\
\text { education }\end{array}$ & $\begin{array}{c}2 \\
\text { Globalization } \\
\text { model }\end{array}$ & $\begin{array}{c}3 \\
\text { Combined } \\
\text { model }\end{array}$ & $\begin{array}{c}4 \\
\text { Interaction } \\
\text { model }\end{array}$ \\
\hline Hi. serv. & $\begin{array}{c}-0.94^{* *} \\
(0.30)\end{array}$ & & $\begin{array}{l}-0.72^{*} \\
(0.31)\end{array}$ & $\begin{array}{l}-0.82^{*} \\
(0.36)\end{array}$ \\
\hline Lo. serv. & $\begin{array}{l}-0.30 \\
(0.28)\end{array}$ & & $\begin{array}{l}-0.10 \\
(0.28)\end{array}$ & $\begin{array}{l}-0.18 \\
(0.34)\end{array}$ \\
\hline Rout.nman & $\begin{array}{l}-0.14 \\
(0.30)\end{array}$ & & $\begin{array}{l}-0.06 \\
(0.30)\end{array}$ & $\begin{array}{l}-0.10 \\
(0.34)\end{array}$ \\
\hline Petite b. & $\begin{array}{l}-1.06^{* * *} \\
(0.37)\end{array}$ & & $\begin{array}{l}-0.80^{*} \\
(0.38)\end{array}$ & $\begin{array}{l}-0.71 \\
(0.47)\end{array}$ \\
\hline Skilled w. & $\begin{array}{c}0.74^{*} \\
(0.35)\end{array}$ & & $\begin{array}{c}0.75^{*} \\
(0.35)\end{array}$ & $\begin{array}{c}0.66 \\
(0.40)\end{array}$ \\
\hline Medium edu & $\begin{array}{c}-0.31 \\
(0.24)\end{array}$ & & $\begin{array}{l}-0.28 \\
(0.24)\end{array}$ & $\begin{array}{l}-0.29 \\
(0.24)\end{array}$ \\
\hline Higher edu & $-1.26^{* * *}$ & & $-1.18^{* * *}$ & $-1.18^{* * *}$ \\
\hline
\end{tabular}


Intermediate

$-0.82^{* * *}$

$-0.60^{* *}$

$-0.61^{* *}$

$(0.21)$

(0.21)

$(0.21)$

Cosmopolitan

$-1.88^{* * *}$

$-1.54^{* * *}$

$-1.54^{* * *}$

(0.34)

(0.34)

(0.34)

Offshorability

$-0.09^{* * *}$

$-0.07^{* * *}$

$-0.12$

(0.03)

(0.03)

(0.10)

Hi. serv. \#

Offshorability

0.06

Lo. serv. \#

0.05

Offshorability

Rout.nman \#

0.04

Offshorability

Petite b. \# Offshorability

Skilled w. \#

0.07

Offshorability

Female

$0.53^{* *}$

$0.39^{*}$

$0.47^{* *}$

$0.48^{* *}$

(0.17)

(0.16)

(0.17)

(0.17)

Age

$$
0.01
$$

0.00

0.01

0.01

$(0.01)$

$(0.01)$

(0.01)

$(0.01)$

Urban-rural

$-0.08^{*}$

$-0.09^{*}$

$-0.06$

$-0.06$

residence

$(0.04)$

(0.04)

(0.04)

(0.04)

\begin{tabular}{lcccc} 
Constant & $5.34^{* * *}$ & $5.25^{* * *}$ & $5.63^{* * *}$ & $5.67^{* * *}$ \\
& $(0.42)$ & $(0.33)$ & $(0.41)$ & $(0.44)$ \\
\hline Observations & 964 & 964 & 964 & 964 \\
$R^{2}$ & 0.119 & 0.075 & 0.151 & 0.151 \\
Adjusted $R^{2}$ & 0.110 & 0.070 & 0.139 & 0.135 \\
\hline
\end{tabular}

Standard errors in parentheses

${ }^{*} p<0.05,{ }^{* *} p<0.01,{ }^{* * *} p<0.001$

Table A.5.2.8: Explaining EU Attitudes in Sweden

\begin{tabular}{lcccc} 
& $\begin{array}{c}\text { Class \& } \\
\text { education }\end{array}$ & $\begin{array}{c}\text { Globalization } \\
\text { model }\end{array}$ & $\begin{array}{c}\text { Combined } \\
\text { model }\end{array}$ & $\begin{array}{c}\text { Interaction } \\
\text { model }\end{array}$ \\
\hline Hi. serv. & $-1.41^{* *}$ & & $-1.48^{* * *}$ & $-2.09^{* * *}$ \\
& $(0.44)$ & & $(0.44)$ & $(0.54)$ \\
Lo. serv. & $-0.94^{*}$ & & $-1.04^{* *}$ & $-1.15^{* *}$ \\
& $(0.38)$ & & $(0.38)$ & $(0.44)$ \\
Rout.nman & 0.15 & & 0.14 & 0.20 \\
& $(0.39)$ & & $(0.38)$ & $(0.42)$
\end{tabular}


Petite b.

$-1.60^{* *}$

$(0.55)$

Skilled w.

$-0.01$

(0.45)

$-0.88^{* *}$

Medium edu

(0.32)

Higher edu

$-1.78^{* * *}$

(0.35)

Intermediate

Cosmopolitan

Offshorability

Hi. serv. \#

Offshorability

Lo. serv. \#

Offshorability

Rout.nman \#

Offshorability

Petite b. \# Offshorability

$-0.54^{*}$

$(0.25)$

$-1.31^{* *}$

(0.40)

$-0.04$

(0.03)

$-1.77^{* *}$

(0.54)

$-1.61^{* *}$

(0.61)

0.01

(0.46)

$-0.37$

(0.51)

$-0.96^{* *}$

(0.32)

$-0.99^{* *}$

(0.32)

$-1.79^{* * *}$

(0.34)

$-1.85^{\text {*** }}$

(0.35)

$-0.47^{*}$

$(0.23)$

$-0.47^{*}$

$(0.23)$

$-1.53^{* * * *}$

$-1.51^{\text {**** }}$

(0.36)

(0.37)

0.00

(0.03)

$-0.10$

(0.12)

0.23

(0.14)

0.10

(0.13)

0.01

(0.14)

$-0.05$

(0.21)

Skilled w. \#

Offshorability

0.23

(0.18)

Female

$0.49^{*}$

(0.21)

0.41

(0.21)

0.39

(0.21)

0.39

$-0.01$

(0.01)

$-0.00$

(0.01)

$-0.00$

(0.01)

$-0.00$

$-0.08$

(0.05)

$-0.16^{* *}$

(0.05)

$-0.07$

(0.05)

$-0.06$

(0.05)

\begin{tabular}{lcccc} 
Constant & $7.64^{* * * *}$ & $6.61^{* * *}$ & $8.00^{* * *}$ & $8.12^{\text {**** }}$ \\
& $(0.56)$ & $(0.45)$ & $(0.56)$ & $(0.59)$ \\
\hline Observations & 656 & 656 & 656 & 656 \\
$R^{2}$ & 0.160 & 0.052 & 0.191 & 0.202 \\
Adjusted $R^{2}$ & 0.147 & 0.043 & 0.175 & 0.179 \\
\hline
\end{tabular}




\section{A.5.3: Country specific analyses of immigration attitudes}

Table A.5.3.1: Explaining Immigration Attitudes in Austria

\begin{tabular}{|c|c|c|c|c|}
\hline & $\begin{array}{c}1 \\
\text { Class \& } \\
\text { education }\end{array}$ & $\begin{array}{c}2 \\
\text { Globalization } \\
\text { model }\end{array}$ & $\begin{array}{c}3 \\
\text { Combined } \\
\text { model }\end{array}$ & $\begin{array}{c}4 \\
\text { Interaction } \\
\text { model }\end{array}$ \\
\hline Hi. serv. & $\begin{array}{c}0.18 \\
(0.31)\end{array}$ & & $\begin{array}{l}-0.03 \\
(0.29)\end{array}$ & $\begin{array}{l}-0.19 \\
(0.31)\end{array}$ \\
\hline Lo. serv. & $\begin{array}{c}0.02 \\
(0.27)\end{array}$ & & $\begin{array}{l}-0.18 \\
(0.27)\end{array}$ & $\begin{array}{l}-0.11 \\
(0.30)\end{array}$ \\
\hline Rout.nman & $\begin{array}{c}0.42 \\
(0.25)\end{array}$ & & $\begin{array}{c}0.24 \\
(0.24)\end{array}$ & $\begin{array}{c}0.22 \\
(0.25)\end{array}$ \\
\hline Petite b. & $\begin{array}{l}-0.20 \\
(0.31)\end{array}$ & & $\begin{array}{l}-0.28 \\
(0.30)\end{array}$ & $\begin{array}{c}0.10 \\
(0.41)\end{array}$ \\
\hline Skilled w. & $\begin{array}{l}-0.35 \\
(0.28)\end{array}$ & & $\begin{array}{l}-0.23 \\
(0.25)\end{array}$ & $\begin{array}{l}-0.25 \\
(0.27)\end{array}$ \\
\hline Medium edu & $\begin{array}{c}0.28 \\
(0.22)\end{array}$ & & $\begin{array}{c}0.38 \\
(0.21)\end{array}$ & $\begin{array}{c}0.41 \\
(0.22)\end{array}$ \\
\hline Higher edu & $\begin{array}{l}1.84^{* * *} \\
(0.33)\end{array}$ & & $\begin{array}{l}1.49^{* * *} \\
(0.32)\end{array}$ & $\begin{array}{l}1.56^{* * *} \\
(0.32)\end{array}$ \\
\hline Intermediate & & $\begin{array}{l}1.34^{* * *} \\
(0.22)\end{array}$ & $\begin{array}{l}1.21^{* * *} \\
(0.22)\end{array}$ & $\begin{array}{l}1.21^{* * *} \\
(0.22)\end{array}$ \\
\hline Cosmopolitan & & $\begin{array}{l}2.56^{* * *} \\
(0.23)\end{array}$ & $\begin{array}{l}2.37^{* * * *} \\
(0.23)\end{array}$ & $\begin{array}{c}2.35^{* * *} \\
(0.23)\end{array}$ \\
\hline Offshorability & & $\begin{array}{c}0.02 \\
(0.02)\end{array}$ & $\begin{array}{c}0.02 \\
(0.02)\end{array}$ & $\begin{array}{c}0.03 \\
(0.09)\end{array}$ \\
\hline $\begin{array}{l}\text { Hi. serv. \# } \\
\text { Offshorability }\end{array}$ & & & & $\begin{array}{l}0.08 \\
(0.12)\end{array}$ \\
\hline $\begin{array}{l}\text { Lo. serv. \# } \\
\text { Offshorability }\end{array}$ & & & & $\begin{array}{l}-0.04 \\
(0.11)\end{array}$ \\
\hline $\begin{array}{l}\text { Rout.nman \# } \\
\text { Offshorability }\end{array}$ & & & & $\begin{array}{l}-0.00 \\
(0.10)\end{array}$ \\
\hline Petite b. \# Offshorability & & & & $\begin{array}{l}-0.12 \\
(0.13)\end{array}$ \\
\hline $\begin{array}{l}\text { Skilled w. \# } \\
\text { Offshorability }\end{array}$ & & & & $\begin{array}{l}-0.01 \\
(0.11)\end{array}$ \\
\hline Female & -0.25 & -0.00 & -0.08 & -0.10 \\
\hline
\end{tabular}




\begin{tabular}{lcccc} 
& $(0.15)$ & $(0.13)$ & $(0.14)$ & $(0.14)$ \\
Age & $-0.02^{* * *}$ & $-0.01^{* * *}$ & $-0.01^{*}$ & $-0.01^{*}$ \\
& $(0.00)$ & $(0.00)$ & $(0.00)$ & $(0.00)$ \\
Urban-rural & & & & \\
residence & $0.14^{* * *}$ & $0.10^{* * *}$ & $0.09^{* * *}$ & $0.09^{* * *}$ \\
& $(0.03)$ & $(0.03)$ & $(0.03)$ & $(0.03)$ \\
Constant & & & & \\
& $4.04^{* * *}$ & $3.44^{* * *}$ & $2.97^{* * *}$ & $2.97^{* * *}$ \\
\hline Observations & $(0.37)$ & $(0.26)$ & $(0.34)$ & $0.35)$ \\
$R^{2}$ & 960 & 960 & 960 & 960 \\
Adjusted $R^{2}$ & 0.136 & 0.230 & 0.260 & 0.263 \\
\hline
\end{tabular}

Table A.5.3.2: Explaining Immigration Attitudes in France

\begin{tabular}{|c|c|c|c|c|}
\hline & $\begin{array}{c}1 \\
\text { Class \& } \\
\text { education }\end{array}$ & $\begin{array}{c}2 \\
\begin{array}{c}\text { Globalization } \\
\text { model }\end{array} \\
\end{array}$ & $\begin{array}{c}3 \\
\text { Combined } \\
\text { model }\end{array}$ & $\begin{array}{c}4 \\
\text { Interaction } \\
\text { model } \\
\end{array}$ \\
\hline Hi. serv. & $\begin{array}{l}0.79^{* *} \\
(0.26)\end{array}$ & & $\begin{array}{l}0.70^{* *} \\
(0.25)\end{array}$ & $\begin{array}{c}0.37 \\
(0.32)\end{array}$ \\
\hline Lo. serv. & $\begin{array}{c}0.80^{* * *} \\
(0.23)\end{array}$ & & $\begin{array}{l}0.71^{* *} \\
(0.22)\end{array}$ & $\begin{array}{l}1.08^{* * *} \\
(0.27)\end{array}$ \\
\hline Rout.nman & $\begin{array}{l}0.56^{*} \\
(0.23)\end{array}$ & & $\begin{array}{l}0.53^{*} \\
(0.22)\end{array}$ & $\begin{array}{c}0.52 \\
(0.27)\end{array}$ \\
\hline Petite b. & $\begin{array}{c}0.14 \\
(0.29)\end{array}$ & & $\begin{array}{c}0.10 \\
(0.29)\end{array}$ & $\begin{array}{c}0.79 \\
(0.57)\end{array}$ \\
\hline Skilled w. & $\begin{array}{l}-0.16 \\
(0.25)\end{array}$ & & $\begin{array}{l}-0.16 \\
(0.24)\end{array}$ & $\begin{array}{c}-0.44 \\
(0.27)\end{array}$ \\
\hline Medium edu & $\begin{array}{c}0.22 \\
(0.19)\end{array}$ & & $\begin{array}{c}0.16 \\
(0.18)\end{array}$ & $\begin{array}{c}0.15 \\
(0.18)\end{array}$ \\
\hline Higher edu & $\begin{array}{c}0.85^{* * *} \\
(0.22)\end{array}$ & & $\begin{array}{l}0.60^{* * *} \\
(0.22)\end{array}$ & $\begin{array}{l}0.58^{* *} \\
(0.22)\end{array}$ \\
\hline Intermediate & & $\begin{array}{l}1.08^{* * *} \\
(0.17)\end{array}$ & $\begin{array}{l}0.91^{* * *} \\
(0.17)\end{array}$ & $\begin{array}{l}0.94^{* * *} \\
(0.17)\end{array}$ \\
\hline Cosmopolitan & & $\begin{array}{l}1.71^{* * *} \\
(0.16)\end{array}$ & $\begin{array}{l}1.52^{* * *} \\
(0.16)\end{array}$ & $\begin{array}{l}1.52^{* * *} \\
(0.16)\end{array}$ \\
\hline Offshorability & & $\begin{array}{c}0.03 \\
(0.02)\end{array}$ & $\begin{array}{c}0.00 \\
(0.02)\end{array}$ & $\begin{array}{c}0.01 \\
(0.06)\end{array}$ \\
\hline $\begin{array}{l}\text { Hi. serv. \# } \\
\text { Offshorability }\end{array}$ & & & & $\begin{array}{c}0.08 \\
(0.07)\end{array}$ \\
\hline $\begin{array}{l}\text { Lo. serv. \# } \\
\text { Offshorability }\end{array}$ & & & & $\begin{array}{l}-0.10 \\
(0.07)\end{array}$ \\
\hline $\begin{array}{l}\text { Rout.nman \# } \\
\text { Offshorability }\end{array}$ & & & & 0.01 \\
\hline
\end{tabular}


Petite b. \# Offshorability

Skilled w. \#

Offshorability

Female

$$
0.01
$$

(0.14)

0.20

(0.13)

0.06

0.03

Age

$$
\begin{gathered}
-0.02^{* * *} \\
(0.00)
\end{gathered}
$$

$-0.02^{* * *}$

(0.13)

(0.13)

Age

$(0.00)$

$-0.02^{* * *}$

$-0.02^{* * *}$

(0.00)

(0.00)

Urban-rural

$0.08^{* *}$

(0.02)

$0.06^{* *}$

(0.02)

0.04

0.04

residence

$5.06^{* * *}$

$5.31^{* * * *}$

(0.02)

(0.02)

\begin{tabular}{lcccc} 
Constant & $5.06^{* * *}$ & $5.31^{* * *}$ & $4.75^{* * *}$ & $4.78^{* * *}$ \\
& $(0.33)$ & $(0.25)$ & $(0.32)$ & $(0.33)$ \\
\hline Observations & 1123 & 1123 & 1123 & 1123 \\
$R^{2}$ & 0.137 & 0.167 & 0.208 & 0.221 \\
Adjusted $R^{2}$ & 0.129 & 0.162 & 0.199 & 0.208 \\
\hline Standard errors in parentheses & & &
\end{tabular}

Standard errors in parentheses

\begin{tabular}{|c|c|c|c|c|}
\hline & $\begin{array}{c}1 \\
\text { Class \& } \\
\text { education }\end{array}$ & $\begin{array}{c}2 \\
\begin{array}{c}\text { Globalization } \\
\text { model }\end{array} \\
\end{array}$ & $\begin{array}{c}3 \\
\text { Combined } \\
\text { model }\end{array}$ & $\begin{array}{c}4 \\
\text { Interaction } \\
\text { model } \\
\end{array}$ \\
\hline Hi. serv. & $\begin{array}{c}0.62 \\
(0.36)\end{array}$ & & $\begin{array}{c}0.36 \\
(0.35)\end{array}$ & $\begin{array}{c}0.55 \\
(0.39)\end{array}$ \\
\hline Lo. serv. & $\begin{array}{c}0.40 \\
(0.29)\end{array}$ & & $\begin{array}{c}0.28 \\
(0.28)\end{array}$ & $\begin{array}{c}0.51 \\
(0.34)\end{array}$ \\
\hline Rout.nman & $\begin{array}{l}-0.20 \\
(0.29)\end{array}$ & & $\begin{array}{l}-0.09 \\
(0.27)\end{array}$ & $\begin{array}{l}-0.11 \\
(0.30)\end{array}$ \\
\hline Petite b. & $\begin{array}{c}0.53 \\
(0.43)\end{array}$ & & $\begin{array}{c}0.48 \\
(0.42)\end{array}$ & $\begin{array}{c}0.97 \\
(0.53)\end{array}$ \\
\hline Skilled w. & $\begin{array}{l}-0.74^{*} \\
(0.30)\end{array}$ & & $\begin{array}{l}-0.66^{*} \\
(0.30)\end{array}$ & $\begin{array}{l}-0.61 \\
(0.33)\end{array}$ \\
\hline Medium edu & $\begin{array}{c}0.37 \\
(0.28)\end{array}$ & & $\begin{array}{l}0.54^{*} \\
(0.27)\end{array}$ & $\begin{array}{c}0.54^{*} \\
(0.27)\end{array}$ \\
\hline Higher edu & $\begin{array}{c}0.77^{*} \\
(0.33)\end{array}$ & & $\begin{array}{l}0.93^{\text {** }} \\
(0.32)\end{array}$ & $\begin{array}{l}0.91^{* *} \\
(0.32)\end{array}$ \\
\hline Intermediate & & $\begin{array}{c}0.77^{* * *} \\
(0.23)\end{array}$ & $\begin{array}{l}0.66^{\text {** }} \\
(0.21)\end{array}$ & $\begin{array}{l}0.64^{* *} \\
(0.21)\end{array}$ \\
\hline Cosmopolitan & & $\begin{array}{l}1.55^{* * *} \\
(0.21)\end{array}$ & $\begin{array}{l}1.42^{* * * *} \\
(0.21)\end{array}$ & $\begin{array}{l}1.44^{* * *} \\
(0.21)\end{array}$ \\
\hline
\end{tabular}

${ }^{*} p<0.05,{ }^{* *} p<0.01,{ }^{* * *} p<0.001$

Table A.5.3.3: Explaining Immigration Attitudes in Germany 
Offshorability

$\begin{array}{ccc}0.03 & 0.02 & 0.07 \\ (0.03) & (0.03) & (0.07)\end{array}$

Hi. serv. \#

$-0.09$

Offshorability

Lo. serv. \#

$-0.10$

Offshorability

Rout.nman \#

0.03

Offshorability

Petite b. \# Offshorability

Skilled w. \# $-0.05$

Offshorability

Female

0.21

0.23

0.20

0.15

(0.19)

(0.16)

(0.17)

(0.18)

Age

$-0.01^{*}$

$-0.01$

$-0.01^{*}$

$-0.01^{*}$

(0.01)

(0.01)

$(0.01)$

\begin{tabular}{lcccc} 
Urban-rural & 0.04 & -0.00 & 0.00 & 0.00 \\
residence & $(0.05)$ & $(0.05)$ & $(0.04)$ & $(0.04)$ \\
& & & & $3.76^{* * *}$ \\
Constant & $4.38^{* * *}$ & $4.04^{* * *}$ & $(0.42)$ & $(0.43)$ \\
\hline Observations & $(0.44)$ & $(0.32)$ & 825 & 825 \\
$R^{2}$ & 825 & 825 & 0.163 & 0.169 \\
Adjusted $R^{2}$ & 0.089 & 0.101 & 0.149 & 0.150 \\
\hline
\end{tabular}

Standard errors in parentheses

${ }^{*} p<0.05,{ }^{* *} p<0.01,{ }^{* * *} p<0.001$

Table A.5.3.4: Explaining Immigration Attitudes in the Netherlands

\begin{tabular}{|c|c|c|c|c|}
\hline & $\begin{array}{c}1 \\
\text { Class \& } \\
\text { education }\end{array}$ & $\begin{array}{c}2 \\
\text { Globalization } \\
\text { model }\end{array}$ & $\begin{array}{c}3 \\
\text { Combined } \\
\text { model }\end{array}$ & $\begin{array}{c}4 \\
\text { Interaction } \\
\text { model }\end{array}$ \\
\hline Hi. serv. & $\begin{array}{c}0.48^{*} \\
(0.24)\end{array}$ & & $\begin{array}{c}0.45 \\
(0.24)\end{array}$ & $\begin{array}{c}0.55 \\
(0.28)\end{array}$ \\
\hline Lo. serv. & $\begin{array}{c}0.52^{*} \\
(0.23)\end{array}$ & & $\begin{array}{l}0.46^{*} \\
(0.23)\end{array}$ & $\begin{array}{l}0.59^{*} \\
(0.27)\end{array}$ \\
\hline Rout.nman & $\begin{array}{c}0.33 \\
(0.23)\end{array}$ & & $\begin{array}{c}0.26 \\
(0.23)\end{array}$ & $\begin{array}{c}0.47 \\
(0.27)\end{array}$ \\
\hline Petite b. & $\begin{array}{c}0.28 \\
(0.29)\end{array}$ & & $\begin{array}{c}0.27 \\
(0.28)\end{array}$ & $\begin{array}{l}-0.01 \\
(0.41)\end{array}$ \\
\hline
\end{tabular}


Skilled w. $\quad 0.05$

(0.28)

Medium edu

Higher edu

Intermediate

Cosmopolitan

Offshorability

Hi. serv. \#

Offshorability

Lo. serv. \#

Offshorability

Rout.nman \#

Offshorability

Petite b. \# Offshorability

Skilled w. \#

Offshorability

Female

$$
\begin{gathered}
0.04 \\
(0.12)
\end{gathered}
$$

Age

$$
\begin{gathered}
-0.00 \\
(0.00)
\end{gathered}
$$

$-0.01^{*}$

$-0.00$

$-0.00$

(0.00)

(0.00)

Urban-rural

0.03

$0.07^{*}$

0.02

0.02

residence

(0.03)

(0.03)

(0.03)

\begin{tabular}{lcccc} 
Constant & $3.89^{* * *}$ & $4.39^{* * *}$ & $3.72^{* * *}$ & $3.62^{* * *}$ \\
& $(0.32)$ & $(0.24)$ & $(0.31)$ & $(0.33)$ \\
\hline Observations & 1149 & 1149 & 1149 & 1149 \\
$R^{2}$ & 0.113 & 0.076 & 0.155 & 0.160 \\
Adjusted $R^{2}$ & 0.105 & 0.071 & 0.145 & 0.147
\end{tabular}

Standard errors in parentheses

${ }^{*} p<0.05,{ }^{* *} p<0.01,{ }^{* * *} p<0.001$

Table A.5.3.5: Explaining Immigration Attitudes in Switzerland

$\begin{array}{cccc}1 & 2 & 3 & 4 \\ \text { Class \& } & \text { Globalization } & \text { Combined } & \text { Interaction } \\ \text { education } & \text { model } & \text { model } & \text { model }\end{array}$




\begin{tabular}{|c|c|c|c|c|}
\hline Hi. serv. & $\begin{array}{c}0.39 \\
(0.29)\end{array}$ & & $\begin{array}{c}0.24 \\
(0.28)\end{array}$ & $\begin{array}{c}0.08 \\
(0.32)\end{array}$ \\
\hline Lo. serv. & $\begin{array}{c}0.46 \\
(0.24)\end{array}$ & & $\begin{array}{c}0.28 \\
(0.24)\end{array}$ & $\begin{array}{c}0.09 \\
(0.26)\end{array}$ \\
\hline Rout.nman & $\begin{array}{c}0.12 \\
(0.24)\end{array}$ & & $\begin{array}{c}0.06 \\
(0.23)\end{array}$ & $\begin{array}{c}0.08 \\
(0.25)\end{array}$ \\
\hline Petite $b$. & $\begin{array}{l}-0.25 \\
(0.34)\end{array}$ & & $\begin{array}{c}-0.21 \\
(0.33)\end{array}$ & $\begin{array}{l}-0.20 \\
(0.38)\end{array}$ \\
\hline Skilled w. & $\begin{array}{l}-0.00 \\
(0.27)\end{array}$ & & $\begin{array}{l}-0.08 \\
(0.26)\end{array}$ & $\begin{array}{l}-0.10 \\
(0.30)\end{array}$ \\
\hline Medium edu & $\begin{array}{l}-0.01 \\
(0.21)\end{array}$ & & $\begin{array}{c}0.06 \\
(0.20)\end{array}$ & $\begin{array}{c}0.10 \\
(0.20)\end{array}$ \\
\hline Higher edu & $\begin{array}{c}0.63^{*} \\
(0.27)\end{array}$ & & $\begin{array}{l}0.58^{*} \\
(0.25)\end{array}$ & $\begin{array}{l}0.62^{*} \\
(0.25)\end{array}$ \\
\hline Intermediate & & $\begin{array}{l}1.03^{* * * *} \\
(0.14)\end{array}$ & $\begin{array}{c}0.90^{* * * *} \\
(0.15)\end{array}$ & $\begin{array}{l}0.92^{* * *} \\
(0.15)\end{array}$ \\
\hline Cosmopolitan & & $\begin{array}{l}1.49^{* * *} \\
(0.18)\end{array}$ & $\begin{array}{c}1.41^{* * * *} \\
(0.18)\end{array}$ & $\begin{array}{l}1.44^{* * *} \\
(0.18)\end{array}$ \\
\hline Offshorability & & $\begin{array}{c}0.01 \\
(0.02)\end{array}$ & $\begin{array}{c}-0.01 \\
(0.02)\end{array}$ & $\begin{array}{l}-0.12 \\
(0.12)\end{array}$ \\
\hline $\begin{array}{l}\text { Hi. serv. \# } \\
\text { Offshorability }\end{array}$ & & & & $\begin{array}{l}0.14 \\
(0.13)\end{array}$ \\
\hline $\begin{array}{l}\text { Lo. serv. \# } \\
\text { Offshorability }\end{array}$ & & & & $\begin{array}{l}0.15 \\
(0.12)\end{array}$ \\
\hline $\begin{array}{l}\text { Rout.nman \# } \\
\text { Offshorability }\end{array}$ & & & & $\begin{array}{l}0.02 \\
(0.13)\end{array}$ \\
\hline Petite b. \# Offshorability & & & & $\begin{array}{c}0.08 \\
(0.15)\end{array}$ \\
\hline $\begin{array}{l}\text { Skilled w.\# } \\
\text { Offshorability }\end{array}$ & & & & $\begin{array}{c}0.09 \\
(0.13)\end{array}$ \\
\hline Female & $\begin{array}{c}0.02 \\
(0.14)\end{array}$ & $\begin{array}{l}-0.04 \\
(0.12)\end{array}$ & $\begin{array}{c}0.00 \\
(0.13)\end{array}$ & $\begin{array}{c}0.02 \\
(0.13)\end{array}$ \\
\hline Age & $\begin{array}{c}-0.01^{* * *} \\
(0.00)\end{array}$ & $\begin{array}{l}-0.01^{* *} \\
(0.00)\end{array}$ & $\begin{array}{c}-0.01^{* *} \\
(0.00)\end{array}$ & $\begin{array}{l}-0.01^{*} \\
(0.00)\end{array}$ \\
\hline $\begin{array}{l}\text { Urban-rural } \\
\text { residence }\end{array}$ & $\begin{array}{l}0.08^{*} \\
(0.03)\end{array}$ & $\begin{array}{l}0.07^{*} \\
(0.03)\end{array}$ & $\begin{array}{c}0.06 \\
(0.03)\end{array}$ & $\begin{array}{c}0.06 \\
(0.03)\end{array}$ \\
\hline Constant & $\begin{array}{c}4.78^{* * *} \\
(0.35)\end{array}$ & $\begin{array}{c}4.47^{* * * *} \\
(0.22)\end{array}$ & $\begin{array}{c}4.24^{* * * *} \\
(0.33)\end{array}$ & $\begin{array}{c}4.23^{* * *} \\
(0.34)\end{array}$ \\
\hline
\end{tabular}




\begin{tabular}{lcccc}
\hline Observations & 980 & 980 & 980 & 980 \\
$R^{2}$ & 0.069 & 0.124 & 0.149 & 0.154 \\
Adjusted $R^{2}$ & 0.059 & 0.119 & 0.137 & 0.138 \\
\hline Standard errors in parentheses & & &
\end{tabular}

${ }^{*} p<0.05,{ }^{* *} p<0.01,{ }^{* * *} p<0.001$

Table A.5.3.6: Explaining Immigration Attitudes in the UK

\begin{tabular}{|c|c|c|c|c|}
\hline & $\begin{array}{c}1 \\
\text { Class \& } \\
\text { education }\end{array}$ & $\begin{array}{c}2 \\
\begin{array}{c}\text { Globalization } \\
\text { model }\end{array}\end{array}$ & $\begin{array}{c}3 \\
\text { Combined } \\
\text { model }\end{array}$ & $\begin{array}{c}4 \\
\text { Interaction } \\
\text { model }\end{array}$ \\
\hline Hi. serv. & $\begin{array}{c}0.50 \\
(0.33)\end{array}$ & & $\begin{array}{c}0.46 \\
(0.33)\end{array}$ & $\begin{array}{c}0.22 \\
(0.42)\end{array}$ \\
\hline Lo. serv. & $\begin{array}{l}0.71^{*} \\
(0.31)\end{array}$ & & $\begin{array}{c}0.54 \\
(0.30)\end{array}$ & $\begin{array}{c}0.66 \\
(0.41)\end{array}$ \\
\hline Rout.nman & $\begin{array}{c}0.27 \\
(0.34)\end{array}$ & & $\begin{array}{c}0.07 \\
(0.33)\end{array}$ & $\begin{array}{l}-0.01 \\
(0.40)\end{array}$ \\
\hline Petite b. & $\begin{array}{c}0.51 \\
(0.38)\end{array}$ & & $\begin{array}{c}0.38 \\
(0.38)\end{array}$ & $\begin{array}{l}0.16 \\
(0.47)\end{array}$ \\
\hline Skilled w. & $\begin{array}{l}-0.26 \\
(0.38)\end{array}$ & & $\begin{array}{l}-0.36 \\
(0.36)\end{array}$ & $\begin{array}{l}-0.70 \\
(0.42)\end{array}$ \\
\hline Medium edu & $\begin{array}{c}0.20 \\
(0.24)\end{array}$ & & $\begin{array}{c}0.22 \\
(0.24)\end{array}$ & $\begin{array}{c}0.24 \\
(0.24)\end{array}$ \\
\hline Higher edu & $\begin{array}{l}1.47^{* * * *} \\
(0.24)\end{array}$ & & $\begin{array}{l}1.26^{* * * *} \\
(0.24)\end{array}$ & $\begin{array}{l}1.25^{* * *} \\
(0.24)\end{array}$ \\
\hline Intermediate & & $\begin{array}{l}1.04^{* * *} \\
(0.27)\end{array}$ & $\begin{array}{l}0.80^{* *} \\
(0.26)\end{array}$ & $\begin{array}{l}0.79^{* *} \\
(0.26)\end{array}$ \\
\hline Cosmopolitan & & $\begin{array}{l}1.66^{* * *} \\
(0.30)\end{array}$ & $\begin{array}{l}1.35^{* * * *} \\
(0.28)\end{array}$ & $\begin{array}{l}1.33^{* * * *} \\
(0.28)\end{array}$ \\
\hline Offshorability & & $\begin{array}{c}0.05 \\
(0.03)\end{array}$ & $\begin{array}{c}0.02 \\
(0.03)\end{array}$ & $\begin{array}{l}-0.04 \\
(0.09)\end{array}$ \\
\hline $\begin{array}{l}\text { Hi. serv. \# } \\
\text { Offshorability }\end{array}$ & & & & $\begin{array}{c}0.11 \\
(0.11)\end{array}$ \\
\hline $\begin{array}{l}\text { Lo. serv. \# } \\
\text { Offshorability }\end{array}$ & & & & $\begin{array}{l}0.00 \\
(0.10)\end{array}$ \\
\hline $\begin{array}{l}\text { Rout.nman \# } \\
\text { Offshorability }\end{array}$ & & & & $\begin{array}{l}0.05 \\
(0.11)\end{array}$ \\
\hline Petite b. \# Offshorability & & & & $\begin{array}{c}0.10 \\
(0.13)\end{array}$ \\
\hline $\begin{array}{l}\text { Skilled w. \# } \\
\text { Offshorability }\end{array}$ & & & & $\begin{array}{l}0.19 \\
(0.13)\end{array}$ \\
\hline
\end{tabular}




\begin{tabular}{lcccc} 
Female & -0.04 & 0.15 & 0.10 & 0.07 \\
& $(0.20)$ & $(0.18)$ & $(0.19)$ & $(0.20)$ \\
Age & & & -0.00 \\
& -0.01 & -0.01 & -0.00 & $(0.01)$ \\
& $(0.01)$ & $(0.01)$ & $(0.01)$ & 0.05 \\
Urban-rural & & & 0.05 & $(0.04)$ \\
residence & 0.06 & 0.07 & $(0.04)$ & $2.83^{* * *}$ \\
& $(0.04)$ & $(0.05)$ & & $(0.46)$ \\
Constant & & & $2.69^{* * *}$ & 578 \\
& $3.10^{* * *}$ & $3.24^{* * *}$ & $(0.43)$ & 0.201 \\
\hline Observations & $(0.43)$ & $(0.38)$ & 578 & 0.175 \\
$R^{2}$ & 578 & 578 & 0.195 & 0.176 \\
Adjusted $R^{2}$ & 0.149 & 0.095 & &
\end{tabular}

${ }^{*} p<0.05,{ }^{* *} p<0.01,{ }^{* * *} p<0.001$

Table A.5.3.7: Explaining Immigration Attitudes in Denmark

\begin{tabular}{|c|c|c|c|c|}
\hline & $\begin{array}{c}1 \\
\text { Class \& } \\
\text { education }\end{array}$ & $\begin{array}{c}2 \\
\text { Globalization } \\
\text { model }\end{array}$ & $\begin{array}{c}3 \\
\text { Combined } \\
\text { model }\end{array}$ & $\begin{array}{c}4 \\
\text { Interaction } \\
\text { model }\end{array}$ \\
\hline Hi. serv. & $\begin{array}{c}0.33 \\
(0.22)\end{array}$ & & $\begin{array}{c}0.30 \\
(0.23)\end{array}$ & $\begin{array}{c}0.40 \\
(0.27)\end{array}$ \\
\hline Lo. serv. & $\begin{array}{l}0.45^{*} \\
(0.20)\end{array}$ & & $\begin{array}{l}0.43^{*} \\
(0.21)\end{array}$ & $\begin{array}{l}0.63^{*} \\
(0.25)\end{array}$ \\
\hline Rout.nman & $\begin{array}{c}0.21 \\
(0.23)\end{array}$ & & $\begin{array}{c}0.21 \\
(0.23)\end{array}$ & $\begin{array}{c}0.20 \\
(0.26)\end{array}$ \\
\hline Petite b. & $\begin{array}{c}0.11 \\
(0.30)\end{array}$ & & $\begin{array}{c}0.06 \\
(0.30)\end{array}$ & $\begin{array}{l}-0.08 \\
(0.38)\end{array}$ \\
\hline Skilled w. & $\begin{array}{l}-0.44 \\
(0.24)\end{array}$ & & $\begin{array}{l}-0.43 \\
(0.24)\end{array}$ & $\begin{array}{l}-0.46 \\
(0.28)\end{array}$ \\
\hline Medium edu & $\begin{array}{l}0.34^{*} \\
(0.17)\end{array}$ & & $\begin{array}{c}0.33 \\
(0.17)\end{array}$ & $\begin{array}{c}0.32 \\
(0.17)\end{array}$ \\
\hline Higher edu & $\begin{array}{l}0.96^{* * *} \\
(0.18)\end{array}$ & & $\begin{array}{l}0.93^{* * * *} \\
(0.18)\end{array}$ & $\begin{array}{l}0.92^{* * *} \\
(0.18)\end{array}$ \\
\hline Intermediate & & $\begin{array}{c}0.24 \\
(0.16)\end{array}$ & $\begin{array}{c}0.11 \\
(0.15)\end{array}$ & $\begin{array}{c}0.13 \\
(0.15)\end{array}$ \\
\hline Cosmopolitan & & $\begin{array}{l}0.75^{* *} \\
(0.26)\end{array}$ & $\begin{array}{l}0.54^{*} \\
(0.25)\end{array}$ & $\begin{array}{l}0.56^{*} \\
(0.25)\end{array}$ \\
\hline Offshorability & & $\begin{array}{c}0.03 \\
(0.02)\end{array}$ & $\begin{array}{c}0.00 \\
(0.02)\end{array}$ & $\begin{array}{c}0.04 \\
(0.08)\end{array}$ \\
\hline $\begin{array}{l}\text { Hi. serv. \# } \\
\text { Offshorability }\end{array}$ & & & & $\begin{array}{l}-0.06 \\
(0.09)\end{array}$ \\
\hline $\begin{array}{l}\text { Lo. serv. \# } \\
\text { Offshorability }\end{array}$ & & & & -0.09 \\
\hline
\end{tabular}


Rout.nman \#

$-0.01$

Offshorability

(0.09)

Petite b. \# Offshorability

0.03

(0.12)

Skilled w. \#

0.00

Offshorability

Female

$$
0.19
$$

(0.13)

$0.38^{* *}$

(0.12)

0.20

0.17

Age

$$
\begin{gathered}
-0.02^{* * *} \\
(0.00)
\end{gathered}
$$

$-0.02^{* * *}$

(0.13)

(0.13)

Age

(0.00)

$-0.02^{* * *}$

$-0.02^{* * *}$

(0.00)

(0.00)

Urban-rural

0.03

$(0.03)$

0.05

0.02

0.02

residence

(0.03)

$(0.03)$

(0.03)

\begin{tabular}{lcccc} 
Constant & $5.36^{* * *}$ & $5.73^{* * * *}$ & $5.29^{* * * *}$ & $5.30^{* * *}$ \\
& $(0.28)$ & $(0.23)$ & $(0.28)$ & $(0.30)$ \\
\hline Observations & 993 & 993 & 993 & 993 \\
$R^{2}$ & 0.130 & 0.070 & 0.134 & 0.138 \\
Adjusted $R^{2}$ & 0.121 & 0.065 & 0.123 & 0.122 \\
\hline
\end{tabular}

Standard errors in parentheses

${ }^{*} p<0.05,{ }^{* *} p<0.01,{ }^{* * *} p<0.001$

Table A.5.3.8: Explaining Immigration Attitudes in Norway

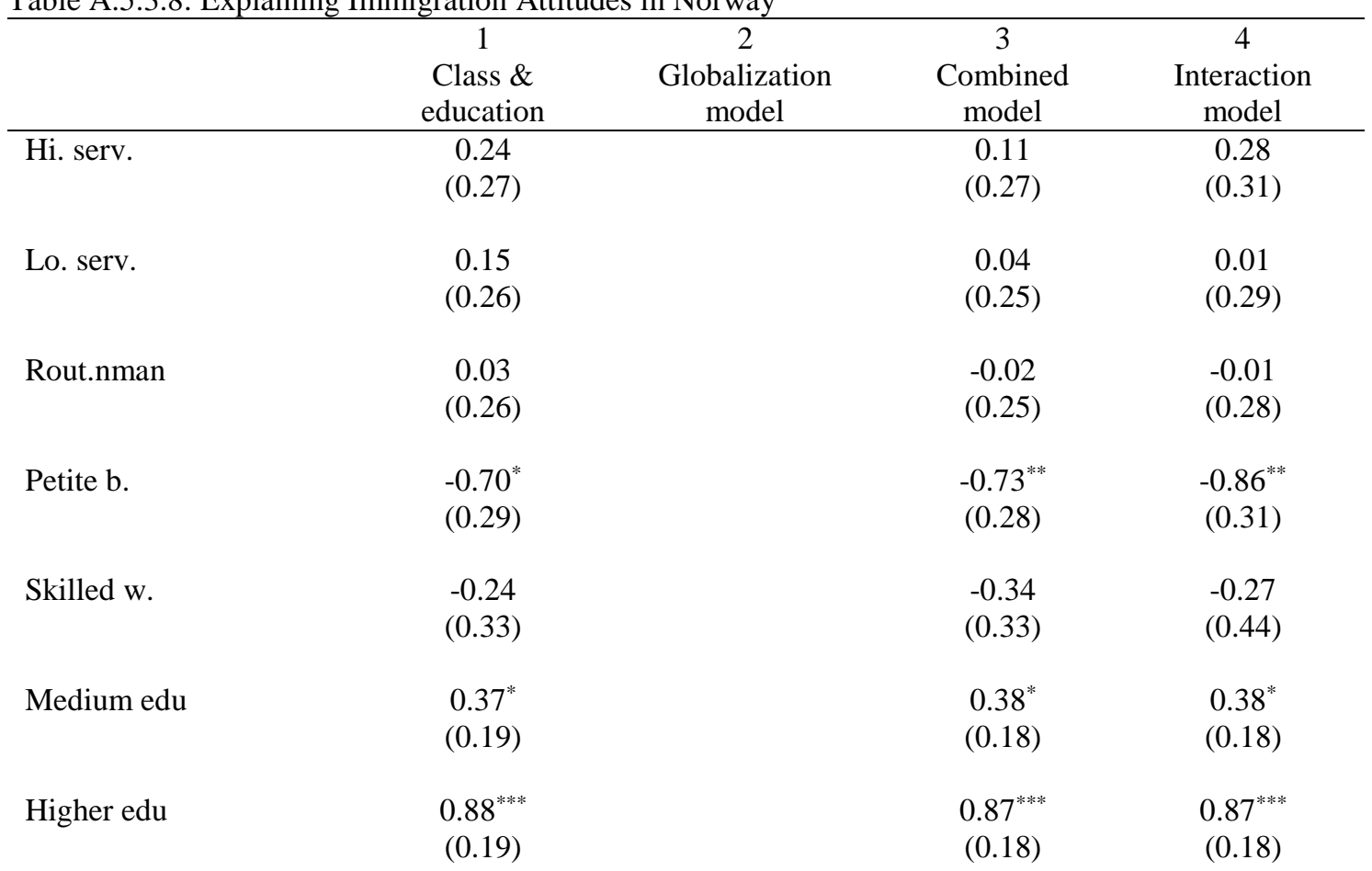


Intermediate

Cosmopolitan

Offshorability

Hi. serv. \#

Offshorability

Lo. serv. \#

Offshorability

Rout.nman \#

Offshorability

Petite b. \# Offshorability

Skilled w. \#

Offshorability

$\begin{array}{ccc}0.34 & 0.30 & 0.29 \\ (0.20) & (0.18) & (0.19) \\ & & \\ 0.77^{* * *} & 0.75^{* * *} & 0.75^{* * *} \\ (0.20) & (0.21) & (0.21) \\ & & \\ 0.07^{* * *} & 0.06^{* *} & 0.09 \\ (0.02) & (0.02) & (0.08)\end{array}$

$-0.07$

(0.09)

$-0.01$

(0.09)

$-0.02$

(0.09)

0.04

(0.11)

$-0.05$

(0.11)

Female

$0.45^{* * *}$

(0.13)

$0.60^{* * *}$

$0.48^{* * * *}$

$0.48^{* * *}$

(0.13)

(0.13)

(0.13)

Age

$-0.01$

(0.00)

$-0.01^{* * *}$

$-0.01$

$-0.01$

(0.00)

(0.00)

(0.00)

Urban-rural

$0.08^{* *}$

(0.03)

$0.11^{* * *}$

$0.06^{*}$

(0.03)

$0.06^{*}$

(0.03)

(0.03)

\begin{tabular}{lcccc} 
Constant & $3.79^{* * *}$ & $4.08^{* * *}$ & $3.69^{* * *}$ & $3.69^{* * *}$ \\
& $(0.29)$ & $(0.24)$ & $(0.29)$ & $(0.31)$ \\
\hline Observations & 723 & 723 & 723 & 723 \\
$R^{2}$ & 0.142 & 0.105 & 0.170 & 0.173 \\
Adjusted $R^{2}$ & 0.130 & 0.098 & 0.155 & 0.152 \\
\hline
\end{tabular}

Standard errors in parentheses

${ }^{*} p<0.05,{ }^{* *} p<0.01,{ }^{* * *} p<0.001$

Table A.5.3.9: Explaining Immigration Attitudes in Sweden

\begin{tabular}{lcccc} 
& $\begin{array}{c}1 \\
\text { Class \& } \\
\text { education }\end{array}$ & $\begin{array}{c}\text { Globalization } \\
\text { model }\end{array}$ & $\begin{array}{c}3 \\
\text { Combined } \\
\text { model }\end{array}$ & $\begin{array}{c}\text { Interaction } \\
\text { model }\end{array}$ \\
\hline Hi. serv. & 0.64 & & $0.77^{*}$ & 0.58 \\
& $(0.39)$ & & $(0.39)$ & $(0.47)$ \\
Lo. serv. & 0.34 & & 0.47 & 0.48 \\
& $(0.33)$ & & $(0.32)$ & $(0.39)$
\end{tabular}




\begin{tabular}{|c|c|c|c|c|}
\hline Rout.nman & $\begin{array}{c}0.15 \\
(0.33)\end{array}$ & & $\begin{array}{c}0.23 \\
(0.33)\end{array}$ & $\begin{array}{c}0.25 \\
(0.38)\end{array}$ \\
\hline Petite $b$. & $\begin{array}{l}-0.45 \\
(0.46)\end{array}$ & & $\begin{array}{l}-0.31 \\
(0.44)\end{array}$ & $\begin{array}{l}-0.08 \\
(0.51)\end{array}$ \\
\hline Skilled w. & $\begin{array}{c}0.31 \\
(0.44)\end{array}$ & & $\begin{array}{c}0.32 \\
(0.43)\end{array}$ & $\begin{array}{c}0.60 \\
(0.48)\end{array}$ \\
\hline Medium edu & $\begin{array}{l}0.68^{*} \\
(0.27)\end{array}$ & & $\begin{array}{l}0.74^{* *} \\
(0.27)\end{array}$ & $\begin{array}{l}0.82^{* *} \\
(0.28)\end{array}$ \\
\hline Higher edu & $\begin{array}{l}1.70^{* * * *} \\
(0.30)\end{array}$ & & $\begin{array}{l}1.71^{* * * *} \\
(0.30)\end{array}$ & $\begin{array}{l}1.78^{* * *} \\
(0.31)\end{array}$ \\
\hline Intermediate & & $\begin{array}{c}0.38 \\
(0.21)\end{array}$ & $\begin{array}{c}0.26 \\
(0.21)\end{array}$ & $\begin{array}{c}0.29 \\
(0.21)\end{array}$ \\
\hline Cosmopolitan & & $\begin{array}{l}0.86^{* *} \\
(0.33)\end{array}$ & $\begin{array}{l}0.97^{* *} \\
(0.31)\end{array}$ & $\begin{array}{l}0.94^{* *} \\
(0.31)\end{array}$ \\
\hline Offshorability & & $\begin{array}{c}0.00 \\
(0.03)\end{array}$ & $\begin{array}{l}-0.02 \\
(0.03)\end{array}$ & $\begin{array}{c}0.00 \\
(0.08)\end{array}$ \\
\hline $\begin{array}{l}\text { Hi. serv. \# } \\
\text { Offshorability }\end{array}$ & & & & $\begin{array}{r}0.03 \\
(0.10)\end{array}$ \\
\hline $\begin{array}{l}\text { Lo. serv. \# } \\
\text { Offshorability }\end{array}$ & & & & $\begin{array}{l}-0.02 \\
(0.09)\end{array}$ \\
\hline $\begin{array}{l}\text { Rout.nman \# } \\
\text { Offshorability }\end{array}$ & & & & $\begin{array}{l}-0.02 \\
(0.09)\end{array}$ \\
\hline Petite b. \# Offshorability & & & & $\begin{array}{l}-0.12 \\
(0.16)\end{array}$ \\
\hline $\begin{array}{l}\text { Skilled w. \# } \\
\text { Offshorability }\end{array}$ & & & & $\begin{array}{l}-0.16 \\
(0.16)\end{array}$ \\
\hline Female & $\begin{array}{l}0.62^{* * * *} \\
(0.18)\end{array}$ & $\begin{array}{l}0.81^{* * * *} \\
(0.18)\end{array}$ & $\begin{array}{c}0.65^{* * *} \\
(0.18)\end{array}$ & $\begin{array}{l}0.63^{* * *} \\
(0.18)\end{array}$ \\
\hline Age & $\begin{array}{c}0.01 \\
(0.01)\end{array}$ & $\begin{array}{c}0.01 \\
(0.01)\end{array}$ & $\begin{array}{c}0.01 \\
(0.01)\end{array}$ & $\begin{array}{c}0.01 \\
(0.01)\end{array}$ \\
\hline $\begin{array}{l}\text { Urban-rural } \\
\text { residence }\end{array}$ & $\begin{array}{c}0.03 \\
(0.05)\end{array}$ & $\begin{array}{c}0.08 \\
(0.05)\end{array}$ & $\begin{array}{c}0.02 \\
(0.05)\end{array}$ & $\begin{array}{c}0.02 \\
(0.05)\end{array}$ \\
\hline Constant & $\begin{array}{l}3.17^{* * * *} \\
(0.54) \\
\end{array}$ & $\begin{array}{c}4.09^{* * * *} \\
(0.45) \\
\end{array}$ & $\begin{array}{c}2.95^{* * *} \\
(0.52) \\
\end{array}$ & $\begin{array}{l}2.86^{* * * *} \\
(0.54) \\
\end{array}$ \\
\hline $\begin{array}{l}\text { Observations } \\
R^{2} \\
\text { Adjusted } R^{2}\end{array}$ & $\begin{array}{c}753 \\
0.118 \\
0.106\end{array}$ & $\begin{array}{c}753 \\
0.044 \\
0.037\end{array}$ & $\begin{array}{c}753 \\
0.134 \\
0.119\end{array}$ & $\begin{array}{c}753 \\
0.138 \\
0.117\end{array}$ \\
\hline
\end{tabular}

Standard errors in parentheses

${ }^{*} p<0.05,{ }^{* *} p<0.01,{ }^{* * *} p<0.001$ 


\section{A.6. The multinomial logistic regression analysis of party preference}

Table A.6.1: Explaining Party Preference. Multinomial logistic regression analyses. Country FE.

\begin{tabular}{|c|c|c|c|c|}
\hline & $\begin{array}{c}1 \\
\text { Class \& } \\
\text { education } \\
\end{array}$ & $\begin{array}{c}2 \\
\text { Globalization } \\
\text { model }\end{array}$ & $\begin{array}{c}3 \\
\begin{array}{c}\text { Combined } \\
\text { model }\end{array} \\
\end{array}$ & $\begin{array}{c}4 \\
\text { Interaction } \\
\text { model } \\
\end{array}$ \\
\hline $\begin{array}{l}\text { Comm__Left_Soc_ } \\
\text { Hi. serv. }\end{array}$ & $\begin{array}{c}0.01 \\
(0.21)\end{array}$ & & $\begin{array}{c}0.04 \\
(0.21)\end{array}$ & $\begin{array}{c}-0.94^{* * * *} \\
(0.24)\end{array}$ \\
\hline Lo. serv. & $\begin{array}{c}0.28 \\
(0.18)\end{array}$ & & $\begin{array}{c}0.31 \\
(0.18)\end{array}$ & $\begin{array}{l}-0.32 \\
(0.22)\end{array}$ \\
\hline Rout.nman & $\begin{array}{c}0.20 \\
(0.18)\end{array}$ & & $\begin{array}{c}0.23 \\
(0.18)\end{array}$ & $\begin{array}{l}-0.20 \\
(0.21)\end{array}$ \\
\hline Petite $b$. & $\begin{array}{l}-0.26 \\
(0.32)\end{array}$ & & $\begin{array}{l}-0.23 \\
(0.32)\end{array}$ & $\begin{array}{l}-1.14^{* *} \\
(0.43)\end{array}$ \\
\hline Skilled w. & $\begin{array}{c}0.01 \\
(0.21)\end{array}$ & & $\begin{array}{c}0.04 \\
(0.21)\end{array}$ & $\begin{array}{l}-0.13 \\
(0.25)\end{array}$ \\
\hline Medium edu & $\begin{array}{l}-0.17 \\
(0.15)\end{array}$ & & $\begin{array}{l}-0.16 \\
(0.15)\end{array}$ & $\begin{array}{l}-0.19 \\
(0.15)\end{array}$ \\
\hline Higher edu & $\begin{array}{c}0.00 \\
(0.17)\end{array}$ & & $\begin{array}{l}-0.03 \\
(0.17)\end{array}$ & $\begin{array}{l}-0.12 \\
(0.16)\end{array}$ \\
\hline Intermediate & & $\begin{array}{l}0.33^{*} \\
(0.13)\end{array}$ & $\begin{array}{l}0.31^{*} \\
(0.13)\end{array}$ & $\begin{array}{l}0.36^{* *} \\
(0.13)\end{array}$ \\
\hline Cosmopolitan & & $\begin{array}{l}0.50^{* * *} \\
(0.15)\end{array}$ & $\begin{array}{l}0.48^{* *} \\
(0.15)\end{array}$ & $\begin{array}{l}1.05^{* * *} \\
(0.16)\end{array}$ \\
\hline offshore10 & & $\begin{array}{l}-0.03 \\
(0.02)\end{array}$ & $\begin{array}{l}-0.03 \\
(0.02)\end{array}$ & $\begin{array}{l}-0.04 \\
(0.06)\end{array}$ \\
\hline Hi. serv. \# offshore10 & & & & $\begin{array}{l}-0.03 \\
(0.07)\end{array}$ \\
\hline Lo. serv. \# offshore10 & & & & $\begin{array}{l}-0.04 \\
(0.07)\end{array}$ \\
\hline $\begin{array}{l}\text { Rout.nman \# } \\
\text { offshore } 10\end{array}$ & & & & $\begin{array}{l}0.04 \\
(0.07)\end{array}$ \\
\hline Petite b. \# offshore10 & & & & $\begin{array}{l}-0.11 \\
(0.12)\end{array}$ \\
\hline Skilled w. \# offshore10 & & & & $\begin{array}{l}-0.01 \\
(0.08)\end{array}$ \\
\hline Female & $\begin{array}{l}-0.08 \\
(0.12)\end{array}$ & $\begin{array}{c}0.01 \\
(0.10)\end{array}$ & $\begin{array}{l}-0.07 \\
(0.12)\end{array}$ & $\begin{array}{c}0.07 \\
(0.12)\end{array}$ \\
\hline age & $\begin{array}{l}-0.01^{* *} \\
(0.00)\end{array}$ & $\begin{array}{l}-0.01^{* *} \\
(0.00)\end{array}$ & $\begin{array}{l}-0.01^{* *} \\
(0.00)\end{array}$ & $\begin{array}{c}-0.01^{* * * *} \\
(0.00)\end{array}$ \\
\hline
\end{tabular}




\begin{tabular}{|c|c|c|c|c|}
\hline urb8 & $\begin{array}{c}0.03 \\
(0.02)\end{array}$ & $\begin{array}{c}0.03 \\
(0.02)\end{array}$ & $\begin{array}{c}0.02 \\
(0.03)\end{array}$ & $\begin{array}{l}0.10^{* * * *} \\
(0.02)\end{array}$ \\
\hline Constant & $\begin{array}{c}-2.49^{* * *} \\
(0.42)\end{array}$ & $\begin{array}{c}-2.65^{* * *} \\
(0.37) \\
\end{array}$ & $\begin{array}{c}-2.62^{* * *} \\
(0.42) \\
\end{array}$ & $\begin{array}{c}-1.86^{\text {*** }} \\
(0.43)\end{array}$ \\
\hline $\begin{array}{l}\text { Green } \\
\text { Hi. serv. }\end{array}$ & $\begin{array}{l}0.60^{*} \\
(0.24)\end{array}$ & & $\begin{array}{l}0.58^{*} \\
(0.24)\end{array}$ & $\begin{array}{l}-0.42 \\
(0.28)\end{array}$ \\
\hline Lo. serv. & $\begin{array}{l}0.78^{* * *} \\
(0.21)\end{array}$ & & $\begin{array}{l}0.76^{* * * *} \\
(0.22)\end{array}$ & $\begin{array}{c}0.17 \\
(0.25)\end{array}$ \\
\hline Rout.nman & $\begin{array}{c}0.27 \\
(0.21)\end{array}$ & & $\begin{array}{c}0.27 \\
(0.21)\end{array}$ & $\begin{array}{l}-0.08 \\
(0.26)\end{array}$ \\
\hline Petite b. & $\begin{array}{c}0.53 \\
(0.34)\end{array}$ & & $\begin{array}{c}0.53 \\
(0.35)\end{array}$ & $\begin{array}{c}0.01 \\
(0.43)\end{array}$ \\
\hline Skilled w. & $\begin{array}{c}0.26 \\
(0.26)\end{array}$ & & $\begin{array}{c}0.34 \\
(0.26)\end{array}$ & $\begin{array}{c}0.14 \\
(0.30)\end{array}$ \\
\hline Medium edu & $\begin{array}{l}-0.02 \\
(0.19)\end{array}$ & & $\begin{array}{l}-0.00 \\
(0.20)\end{array}$ & $\begin{array}{l}-0.03 \\
(0.20)\end{array}$ \\
\hline Higher edu & $\begin{array}{c}0.71^{* * * *} \\
(0.20)\end{array}$ & & $\begin{array}{c}0.67^{* * *} \\
(0.20)\end{array}$ & $\begin{array}{l}0.59^{* *} \\
(0.20)\end{array}$ \\
\hline Intermediate & & $\begin{array}{c}0.52^{* * *} \\
(0.14)\end{array}$ & $\begin{array}{l}0.39^{* *} \\
(0.15)\end{array}$ & $\begin{array}{l}0.44^{* * *} \\
(0.14)\end{array}$ \\
\hline Cosmopolitan & & $\begin{array}{c}0.83^{* * *} \\
(0.14)\end{array}$ & $\begin{array}{c}0.71^{* * *} \\
(0.15)\end{array}$ & $\begin{array}{l}1.28^{* * * *} \\
(0.15)\end{array}$ \\
\hline offshore 10 & & $\begin{array}{c}0.01 \\
(0.02)\end{array}$ & $\begin{array}{l}-0.01 \\
(0.02)\end{array}$ & $\begin{array}{c}0.01 \\
(0.07)\end{array}$ \\
\hline Hi. serv. \# offshore10 & & & & $\begin{array}{l}-0.04 \\
(0.08)\end{array}$ \\
\hline Lo. serv. \# offshore10 & & & & $\begin{array}{l}-0.07 \\
(0.08)\end{array}$ \\
\hline $\begin{array}{l}\text { Rout.nman \# } \\
\text { offshore10 }\end{array}$ & & & & $\begin{array}{l}-0.01 \\
(0.08)\end{array}$ \\
\hline Petite b. \# offshore10 & & & & $\begin{array}{l}-0.26^{*} \\
(0.13)\end{array}$ \\
\hline Skilled w. \# offshore10 & & & & $\begin{array}{c}0.00 \\
(0.10)\end{array}$ \\
\hline Female & $\begin{array}{c}0.47^{* * *} \\
(0.12)\end{array}$ & $\begin{array}{c}0.49^{* * *} \\
(0.11)\end{array}$ & $\begin{array}{c}0.50^{* * *} \\
(0.12)\end{array}$ & $\begin{array}{l}0.64^{* * * *} \\
(0.12)\end{array}$ \\
\hline age & $\begin{array}{c}-0.03^{* * *} \\
(0.00)\end{array}$ & $\begin{array}{c}-0.02^{* * *} \\
(0.00)\end{array}$ & $\begin{array}{c}-0.02^{* * *} \\
(0.00)\end{array}$ & $\begin{array}{c}-0.03^{* * *} \\
(0.00)\end{array}$ \\
\hline urb8 & $\begin{array}{c}0.02 \\
(0.03)\end{array}$ & $\begin{array}{c}0.02 \\
(0.03)\end{array}$ & $\begin{array}{c}0.01 \\
(0.03)\end{array}$ & $\begin{array}{c}0.09^{* * *} \\
(0.03)\end{array}$ \\
\hline
\end{tabular}




\begin{tabular}{|c|c|c|c|c|}
\hline Constant & $\begin{array}{l}-0.38 \\
(0.35) \\
\end{array}$ & $\begin{array}{l}-0.25 \\
(0.24) \\
\end{array}$ & $\begin{array}{l}-0.64 \\
(0.35) \\
\end{array}$ & $\begin{array}{c}0.08 \\
(0.37) \\
\end{array}$ \\
\hline $\begin{array}{l}\text { Soc__Dem_ } \\
\text { Hi. serv. }\end{array}$ & $\begin{array}{c}0.00 \\
(.)\end{array}$ & & $\begin{array}{c}0.00 \\
(.)\end{array}$ & $\begin{array}{c}-1.05^{* * *} \\
(0.18)\end{array}$ \\
\hline Lo. serv. & $\begin{array}{c}0.00 \\
(.)\end{array}$ & & $\begin{array}{c}0.00 \\
(.)\end{array}$ & $\begin{array}{c}-0.61^{\text {**** }} \\
(0.17)\end{array}$ \\
\hline Rout.nman & $\begin{array}{c}0.00 \\
(.)\end{array}$ & & $\begin{array}{c}0.00 \\
(.)\end{array}$ & $\begin{array}{l}-0.23 \\
(0.17)\end{array}$ \\
\hline Petite b. & $\begin{array}{c}0.00 \\
(.)\end{array}$ & & $\begin{array}{c}0.00 \\
(.)\end{array}$ & $\begin{array}{c}-1.09^{* * *} \\
(0.28)\end{array}$ \\
\hline Skilled w. & $\begin{array}{c}0.00 \\
(.)\end{array}$ & & $\begin{array}{c}0.00 \\
(.)\end{array}$ & $\begin{array}{l}-0.16 \\
(0.20)\end{array}$ \\
\hline Medium edu & $\begin{array}{c}0.00 \\
(.)\end{array}$ & & $\begin{array}{c}0.00 \\
(.)\end{array}$ & $\begin{array}{l}-0.01 \\
(0.11)\end{array}$ \\
\hline Higher edu & $\begin{array}{c}0.00 \\
(.)\end{array}$ & & $\begin{array}{c}0.00 \\
(.)\end{array}$ & $\begin{array}{l}-0.07 \\
(0.12)\end{array}$ \\
\hline Intermediate & & $\begin{array}{c}0.00 \\
(.)\end{array}$ & $\begin{array}{c}0.00 \\
(.)\end{array}$ & $\begin{array}{c}0.05 \\
(0.10)\end{array}$ \\
\hline Cosmopolitan & & $\begin{array}{c}0.00 \\
(.)\end{array}$ & $\begin{array}{c}0.00 \\
(.)\end{array}$ & $\begin{array}{l}0.56^{* * * *} \\
(0.13)\end{array}$ \\
\hline offshore 10 & & $\begin{array}{c}0.00 \\
(.)\end{array}$ & $\begin{array}{c}0.00 \\
(.)\end{array}$ & $\begin{array}{c}0.03 \\
(0.05)\end{array}$ \\
\hline Hi. serv. \# offshore10 & & & & $\begin{array}{l}-0.03 \\
(0.06)\end{array}$ \\
\hline Lo. serv. \# offshore10 & & & & $\begin{array}{l}-0.07 \\
(0.05)\end{array}$ \\
\hline $\begin{array}{l}\text { Rout.nman \# } \\
\text { offshore } 10\end{array}$ & & & & $\begin{array}{l}-0.08 \\
(0.06)\end{array}$ \\
\hline Petite b. \# offshore10 & & & & $\begin{array}{l}-0.08 \\
(0.07)\end{array}$ \\
\hline Skilled w. \# offshore10 & & & & $\begin{array}{l}-0.02 \\
(0.06)\end{array}$ \\
\hline Female & $\begin{array}{c}0.00 \\
(.)\end{array}$ & $\begin{array}{c}0.00 \\
(.)\end{array}$ & $\begin{array}{c}0.00 \\
(.)\end{array}$ & $\begin{array}{c}0.14 \\
(0.09)\end{array}$ \\
\hline age & $\begin{array}{c}0.00 \\
(.)\end{array}$ & $\begin{array}{c}0.00 \\
(.)\end{array}$ & $\begin{array}{c}0.00 \\
(.)\end{array}$ & $\begin{array}{l}-0.00 \\
(0.00)\end{array}$ \\
\hline urb8 & $\begin{array}{c}0.00 \\
(.)\end{array}$ & $\begin{array}{c}0.00 \\
(.)\end{array}$ & $\begin{array}{c}0.00 \\
(.)\end{array}$ & $\begin{array}{l}0.08^{* * * *} \\
(0.02)\end{array}$ \\
\hline Constant & 0.00 & 0.00 & 0.00 & $0.69^{* *}$ \\
\hline
\end{tabular}




\begin{tabular}{|c|c|c|c|c|}
\hline & (.) & (.) & (.) & $(0.24)$ \\
\hline $\begin{array}{l}\text { Liberal } \\
\text { Hi. serv. }\end{array}$ & $\begin{array}{l}1.41^{* * *} \\
(0.22)\end{array}$ & & $\begin{array}{l}1.32^{* * * *} \\
(0.23)\end{array}$ & $\begin{array}{c}0.56^{*} \\
(0.27)\end{array}$ \\
\hline Lo. serv. & $\begin{array}{l}1.25^{* * *} \\
(0.21)\end{array}$ & & $\begin{array}{l}1.15^{* * *} \\
(0.22)\end{array}$ & $\begin{array}{c}0.60^{*} \\
(0.27)\end{array}$ \\
\hline Rout.nman & $\begin{array}{l}0.94^{* * *} \\
(0.22)\end{array}$ & & $\begin{array}{l}0.87^{* * *} \\
(0.22)\end{array}$ & $\begin{array}{c}0.50 \\
(0.28)\end{array}$ \\
\hline Petite $b$. & $\begin{array}{l}1.27^{* * *} \\
(0.28)\end{array}$ & & $\begin{array}{l}1.17^{* * * *} \\
(0.29)\end{array}$ & $\begin{array}{c}0.38 \\
(0.37)\end{array}$ \\
\hline Skilled w. & $\begin{array}{c}0.46 \\
(0.27)\end{array}$ & & $\begin{array}{c}0.46 \\
(0.27)\end{array}$ & $\begin{array}{c}0.53 \\
(0.33)\end{array}$ \\
\hline Medium edu & $\begin{array}{c}0.28 \\
(0.16)\end{array}$ & & $\begin{array}{c}0.27 \\
(0.16)\end{array}$ & $\begin{array}{c}0.23 \\
(0.16)\end{array}$ \\
\hline Higher edu & $\begin{array}{l}0.78^{* * *} \\
(0.16)\end{array}$ & & $\begin{array}{l}0.76^{* * *} \\
(0.16)\end{array}$ & $\begin{array}{c}0.67^{* * *} \\
(0.16)\end{array}$ \\
\hline Intermediate & & $\begin{array}{c}0.25^{*} \\
(0.13)\end{array}$ & $\begin{array}{c}0.12 \\
(0.13)\end{array}$ & $\begin{array}{c}0.17 \\
(0.12)\end{array}$ \\
\hline Cosmopolitan & & $\begin{array}{l}0.38^{* *} \\
(0.13)\end{array}$ & $\begin{array}{c}0.24 \\
(0.14)\end{array}$ & $\begin{array}{c}0.80^{* * * *} \\
(0.15)\end{array}$ \\
\hline offshore10 & & $\begin{array}{l}0.08^{* * *} \\
(0.02)\end{array}$ & $\begin{array}{l}0.05^{* *} \\
(0.02)\end{array}$ & $\begin{array}{c}0.12 \\
(0.08)\end{array}$ \\
\hline Hi. serv. \# offshore10 & & & & $\begin{array}{l}-0.14 \\
(0.08)\end{array}$ \\
\hline Lo. serv. \# offshore10 & & & & $\begin{array}{l}-0.11 \\
(0.08)\end{array}$ \\
\hline $\begin{array}{l}\text { Rout.nman \# } \\
\text { offshore } 10\end{array}$ & & & & $\begin{array}{l}-0.03 \\
(0.08)\end{array}$ \\
\hline Petite b. \# offshore10 & & & & $\begin{array}{l}-0.18 \\
(0.10)\end{array}$ \\
\hline Skilled w. \# offshore10 & & & & $\begin{array}{l}-0.15 \\
(0.10)\end{array}$ \\
\hline Female & $\begin{array}{l}-0.25^{*} \\
(0.11)\end{array}$ & $\begin{array}{l}-0.21^{*} \\
(0.10)\end{array}$ & $\begin{array}{l}-0.21^{*} \\
(0.11)\end{array}$ & $\begin{array}{l}-0.08 \\
(0.11)\end{array}$ \\
\hline age & $\begin{array}{l}-0.00 \\
(0.00)\end{array}$ & $\begin{array}{l}-0.01^{*} \\
(0.00)\end{array}$ & $\begin{array}{l}-0.00 \\
(0.00)\end{array}$ & $\begin{array}{c}-0.01^{* *} \\
(0.00)\end{array}$ \\
\hline urb8 & $\begin{array}{c}0.00 \\
(0.02)\end{array}$ & $\begin{array}{c}0.03 \\
(0.02)\end{array}$ & $\begin{array}{l}-0.00 \\
(0.02)\end{array}$ & $\begin{array}{c}0.08^{* * * *} \\
(0.02)\end{array}$ \\
\hline Constant & $\begin{array}{c}-3.09^{* * *} \\
(0.38)\end{array}$ & $\begin{array}{c}-2.12^{* * * *} \\
(0.29)\end{array}$ & $\begin{array}{c}-3.20^{* * * *} \\
(0.38)\end{array}$ & $\begin{array}{c}-2.57^{\text {**** }} \\
(0.40)\end{array}$ \\
\hline
\end{tabular}

CD_Cons_ 


\begin{tabular}{|c|c|c|c|c|}
\hline Hi. serv. & $\begin{array}{l}1.09^{* * *} \\
(0.15)\end{array}$ & & $\begin{array}{l}1.05^{\text {*** }} \\
(0.16)\end{array}$ & $\begin{array}{c}0.00 \\
(.)\end{array}$ \\
\hline Lo. serv. & $\begin{array}{l}0.80^{* * *} \\
(0.14)\end{array}$ & & $\begin{array}{l}0.75^{\text {*** }} \\
(0.14)\end{array}$ & $\begin{array}{c}0.00 \\
(.)\end{array}$ \\
\hline Rout.nman & $\begin{array}{l}0.37^{* *} \\
(0.14)\end{array}$ & & $\begin{array}{l}0.35^{*} \\
(0.15)\end{array}$ & $\begin{array}{c}0.00 \\
(.)\end{array}$ \\
\hline Petite b. & $\begin{array}{l}1.30^{* * *} \\
(0.19)\end{array}$ & & $\begin{array}{l}1.25^{\text {*** }} \\
(0.19)\end{array}$ & $\begin{array}{c}0.00 \\
(.)\end{array}$ \\
\hline Skilled w. & $\begin{array}{c}0.20 \\
(0.17)\end{array}$ & & $\begin{array}{c}0.17 \\
(0.17)\end{array}$ & $\begin{array}{c}0.00 \\
(.)\end{array}$ \\
\hline Medium edu & $\begin{array}{c}0.02 \\
(0.11)\end{array}$ & & $\begin{array}{c}0.01 \\
(0.11)\end{array}$ & $\begin{array}{c}0.00 \\
(.)\end{array}$ \\
\hline Higher edu & $\begin{array}{c}0.04 \\
(0.12)\end{array}$ & & $\begin{array}{c}0.07 \\
(0.12)\end{array}$ & $\begin{array}{c}0.00 \\
(.)\end{array}$ \\
\hline Intermediate & & $\begin{array}{c}0.03 \\
(0.10)\end{array}$ & $\begin{array}{l}-0.05 \\
(0.10)\end{array}$ & $\begin{array}{c}0.00 \\
(.)\end{array}$ \\
\hline Cosmopolitan & & $\begin{array}{c}-0.49^{* * *} \\
(0.13)\end{array}$ & $\begin{array}{c}-0.56^{* * *} \\
(0.13)\end{array}$ & $\begin{array}{c}0.00 \\
(.)\end{array}$ \\
\hline offshore10 & & $\begin{array}{l}0.05^{* * *} \\
(0.01)\end{array}$ & $\begin{array}{l}0.03^{*} \\
(0.01)\end{array}$ & $\begin{array}{c}0.00 \\
(.)\end{array}$ \\
\hline Hi. serv. \# offshore10 & & & & $\begin{array}{c}0.00 \\
(.)\end{array}$ \\
\hline Lo. serv. \# offshore10 & & & & $\begin{array}{c}0.00 \\
(.)\end{array}$ \\
\hline $\begin{array}{l}\text { Rout.nman \# } \\
\text { offshore10 }\end{array}$ & & & & $\begin{array}{c}0.00 \\
(.)\end{array}$ \\
\hline Petite b. \# offshore10 & & & & $\begin{array}{l}0.00 \\
(.)\end{array}$ \\
\hline Skilled w. \# offshore10 & & & & $\begin{array}{c}0.00 \\
(.)\end{array}$ \\
\hline Female & $\begin{array}{l}-0.14 \\
(0.08)\end{array}$ & $\begin{array}{c}-0.20^{* *} \\
(0.08)\end{array}$ & $\begin{array}{l}-0.15 \\
(0.08)\end{array}$ & $\begin{array}{c}0.00 \\
(.)\end{array}$ \\
\hline age & $\begin{array}{c}0.00 \\
(0.00)\end{array}$ & $\begin{array}{l}0.01^{*} \\
(0.00)\end{array}$ & $\begin{array}{c}0.00 \\
(0.00)\end{array}$ & $\begin{array}{c}0.00 \\
(.)\end{array}$ \\
\hline urb8 & $\begin{array}{c}-0.08^{* * *} \\
(0.02)\end{array}$ & $\begin{array}{c}-0.07^{* * * *} \\
(0.02)\end{array}$ & $\begin{array}{c}-0.08^{* * *} \\
(0.02)\end{array}$ & $\begin{array}{c}0.00 \\
(.)\end{array}$ \\
\hline Constant & $\begin{array}{c}-0.85^{* * *} \\
(0.23)\end{array}$ & $\begin{array}{l}-0.32 \\
(0.19) \\
\end{array}$ & $\begin{array}{c}-0.76^{* *} \\
(0.23)\end{array}$ & $\begin{array}{c}0.00 \\
(.)\end{array}$ \\
\hline $\begin{array}{l}\text { Populist_Right } \\
\text { Hi. serv. }\end{array}$ & $\begin{array}{c}0.31 \\
(0.23)\end{array}$ & & $\begin{array}{c}0.34 \\
(0.24)\end{array}$ & $\begin{array}{l}-0.67^{*} \\
(0.28)\end{array}$ \\
\hline
\end{tabular}




\begin{tabular}{|c|c|c|c|c|}
\hline Lo. serv. & $\begin{array}{c}0.00 \\
(0.21)\end{array}$ & & $\begin{array}{c}0.02 \\
(0.21)\end{array}$ & $\begin{array}{l}-0.57^{*} \\
(0.26)\end{array}$ \\
\hline Rout.nman & $\begin{array}{l}-0.07 \\
(0.20)\end{array}$ & & $\begin{array}{l}-0.06 \\
(0.21)\end{array}$ & $\begin{array}{l}-0.19 \\
(0.24)\end{array}$ \\
\hline Petite b. & $\begin{array}{l}0.74^{* *} \\
(0.26)\end{array}$ & & $\begin{array}{l}0.72^{* *} \\
(0.26)\end{array}$ & $\begin{array}{l}-0.26 \\
(0.32)\end{array}$ \\
\hline Skilled w. & $\begin{array}{c}0.33 \\
(0.21)\end{array}$ & & $\begin{array}{c}0.31 \\
(0.21)\end{array}$ & $\begin{array}{c}0.13 \\
(0.26)\end{array}$ \\
\hline Medium edu & $\begin{array}{l}-0.18 \\
(0.16)\end{array}$ & & $\begin{array}{l}-0.19 \\
(0.16)\end{array}$ & $\begin{array}{l}-0.19 \\
(0.16)\end{array}$ \\
\hline Higher edu & $\begin{array}{c}-0.96^{* * *} \\
(0.21)\end{array}$ & & $\begin{array}{c}-0.93^{* * *} \\
(0.21)\end{array}$ & $\begin{array}{c}-1.00^{* * *} \\
(0.21)\end{array}$ \\
\hline Intermediate & & $\begin{array}{c}-0.49^{* *} \\
(0.17)\end{array}$ & $\begin{array}{l}-0.41^{*} \\
(0.17)\end{array}$ & $\begin{array}{l}-0.36^{*} \\
(0.18)\end{array}$ \\
\hline Cosmopolitan & & $\begin{array}{c}-0.90^{* * *} \\
(0.22)\end{array}$ & $\begin{array}{c}-0.83^{* * *} \\
(0.23)\end{array}$ & $\begin{array}{l}-0.26 \\
(0.23)\end{array}$ \\
\hline offshore10 & & $\begin{array}{c}0.00 \\
(0.02)\end{array}$ & $\begin{array}{c}0.01 \\
(0.02)\end{array}$ & $\begin{array}{c}0.08 \\
(0.07)\end{array}$ \\
\hline Hi. serv. \# offshore10 & & & & $\begin{array}{l}-0.07 \\
(0.09)\end{array}$ \\
\hline Lo. serv. \# offshore10 & & & & $\begin{array}{l}-0.11 \\
(0.08)\end{array}$ \\
\hline $\begin{array}{l}\text { Rout.nman \# } \\
\text { offshore10 }\end{array}$ & & & & $\begin{array}{l}-0.16 \\
(0.09)\end{array}$ \\
\hline Petite b. \# offshore10 & & & & $\begin{array}{l}-0.15 \\
(0.10)\end{array}$ \\
\hline Skilled w. \# offshore10 & & & & $\begin{array}{l}-0.04 \\
(0.09)\end{array}$ \\
\hline Female & $\begin{array}{c}-0.45^{* * *} \\
(0.13)\end{array}$ & $\begin{array}{c}-0.56^{* * *} \\
(0.12)\end{array}$ & $\begin{array}{c}-0.47^{* * *} \\
(0.13)\end{array}$ & $\begin{array}{l}-0.34^{* *} \\
(0.13)\end{array}$ \\
\hline age & $\begin{array}{l}-0.01 \\
(0.00)\end{array}$ & $\begin{array}{l}-0.00 \\
(0.00)\end{array}$ & $\begin{array}{l}-0.01^{*} \\
(0.00)\end{array}$ & $\begin{array}{l}-0.01^{* *} \\
(0.00)\end{array}$ \\
\hline urb8 & $\begin{array}{c}-0.08^{* *} \\
(0.03)\end{array}$ & $\begin{array}{c}-0.10^{\text {*** }} \\
(0.03)\end{array}$ & $\begin{array}{c}-0.08^{* *} \\
(0.03)\end{array}$ & $\begin{array}{c}0.01 \\
(0.03)\end{array}$ \\
\hline Constant & $\begin{array}{c}0.21 \\
(0.31) \\
\end{array}$ & $\begin{array}{c}0.27 \\
(0.27) \\
\end{array}$ & $\begin{array}{c}0.39 \\
(0.32) \\
\end{array}$ & $\begin{array}{l}1.04^{* *} \\
(0.34)\end{array}$ \\
\hline $\begin{array}{l}\text { Other } \\
\text { Hi. serv. }\end{array}$ & $\begin{array}{c}0.36 \\
(0.22)\end{array}$ & & $\begin{array}{c}0.38 \\
(0.22)\end{array}$ & $\begin{array}{l}-0.60^{*} \\
(0.27)\end{array}$ \\
\hline Lo. serv. & $0.51^{\text {*** }}$ & & $0.53^{* *}$ & 0.01 \\
\hline
\end{tabular}


Rout.nman

0.18

(0.19)

Petite b.

Skilled w.

0.27

Medium edu

$-0.17$

(0.15)

$-0.44^{*}$

$(0.18)$

Higher edu

Intermediate

Cosmopolitan

offshore 10

Hi. serv. \# offshore10

Lo. serv. \# offshore10

Rout.nman \#

offshore 10

Petite b. \# offshore10

Skilled w. \# offshore10

Female

$-0.28^{*}$

(0.12)

age

$-0.01^{* *}$

$(0.00)$

urb8

$-0.14^{* * *}$
$(0.02)$

$(0.02)$

Constant

$-0.42$

$(0.32)$

Observations

Pseudo $R^{2}$

AIC

$B I C$

0.126

19452.51

20216.99

Standard errors in parentheses

${ }^{*} p<0.05,{ }^{* *} p<0.01,{ }^{* * *} p<0.001$ $\begin{array}{cc}0.20 & -0.01 \\ (0.19) & (0.23)\end{array}$

$1.02^{* * *} \quad 0.22$

(0.26) (0.32)

$\begin{array}{ll}0.26 & 0.09\end{array}$

(0.22) (0.26)

$\begin{array}{ll}-0.17 & -0.18\end{array}$

(0.15) (0.15)

$-0.42^{*} \quad-0.49^{* *}$

(0.18) (0.18)

$-0.16$

$-0.16-0.11$

(0.15)

(0.15)

(0.15)

$-0.36^{*}$

$-0.33$

0.23

(0.17)

(0.17)

(0.18)

0.00

(0.02)

$-0.01$

(0.02)

0.06

(0.06)

$-0.07$

(0.07)

$-0.12$

(0.07)

$-0.09$

$(0.07)$

$-0.19^{*}$

(0.09)

$-0.03$

$(0.08)$

$-0.17$

(0.12)

(0.11)

$-0.30^{*}$

(0.1

$-0.01^{*}$

$-0.01^{\text {** }}$

$-0.01^{* * *}$

(0.00)

(0.00)

$-0.14^{* * *}$

$-0.13^{* * *}$

$-0.05^{*}$

(0.02)

(0.02)

(0.02)

$\begin{array}{lll}-0.30 & -0.35 & 0.31\end{array}$

(0.33)

(0.34)

6039

6039 6039

0.115

0.133

0.135

19653.84

19326.06

19344.38

20257.38

20211.25 
A.7. The full tables including all coefficients.

Table 1. Explaining economic left-right attitudes. OLS.

\begin{tabular}{|c|c|c|c|c|}
\hline & $\begin{array}{c}1 \\
\text { Class and } \\
\text { education }\end{array}$ & $\begin{array}{c}2 \\
\text { Globalization } \\
\text { variables }\end{array}$ & $\begin{array}{c}3 \\
\text { Combined } \\
\text { model }\end{array}$ & $\begin{array}{c}4 \\
\text { Interaction } \\
\text { model }\end{array}$ \\
\hline Class: Hi. serv. & $\begin{array}{c}-0.78^{* * *} \\
(0.07)\end{array}$ & & $\begin{array}{c}-0.74^{* * *} \\
(0.07)\end{array}$ & $\begin{array}{c}-0.74^{* * *} \\
(0.09)\end{array}$ \\
\hline Class: Lo. serv. & $\begin{array}{c}-0.44^{* * *} \\
(0.07)\end{array}$ & & $\begin{array}{c}-0.40^{* * * *} \\
(0.07)\end{array}$ & $\begin{array}{c}-0.32^{* * * *} \\
(0.08)\end{array}$ \\
\hline Class: Rout.nman & $\begin{array}{c}-0.19^{* *} \\
(0.06)\end{array}$ & & $\begin{array}{c}-0.17^{* *} \\
(0.06)\end{array}$ & $\begin{array}{l}-0.14^{*} \\
(0.07)\end{array}$ \\
\hline Class: Petite bourg. & $\begin{array}{c}-0.99^{* * *} \\
(0.09)\end{array}$ & & $\begin{array}{c}-0.94^{* * * *} \\
(0.09)\end{array}$ & $\begin{array}{c}-0.93^{* * * *} \\
(0.13)\end{array}$ \\
\hline Class: Skilled workers & $\begin{array}{l}-0.06 \\
(0.07)\end{array}$ & & $\begin{array}{l}-0.04 \\
(0.07)\end{array}$ & $\begin{array}{l}-0.10 \\
(0.08)\end{array}$ \\
\hline Education: Medium & $\begin{array}{c}-0.18^{* * *} \\
(0.05)\end{array}$ & & $\begin{array}{c}-0.17^{* *} \\
(0.05)\end{array}$ & $\begin{array}{c}-0.17^{* *} \\
(0.05)\end{array}$ \\
\hline Education: Higher & $\begin{array}{l}-0.13^{*} \\
(0.06)\end{array}$ & & $\begin{array}{l}-0.15^{*} \\
(0.06)\end{array}$ & $\begin{array}{l}-0.15^{*} \\
(0.06)\end{array}$ \\
\hline Nat. ID: Intermediate & & $\begin{array}{c}0.01 \\
(0.05)\end{array}$ & $\begin{array}{c}0.07 \\
(0.05)\end{array}$ & $\begin{array}{c}0.07 \\
(0.05)\end{array}$ \\
\hline Nat. ID: Cosmopolitan & & $\begin{array}{l}0.22^{* * * *} \\
(0.06)\end{array}$ & $\begin{array}{l}0.25^{* * *} \\
(0.06)\end{array}$ & $\begin{array}{l}0.26^{* * *} \\
(0.06)\end{array}$ \\
\hline Offshorability & & $\begin{array}{c}-0.04^{* * *} \\
(0.01)\end{array}$ & $\begin{array}{c}-0.02^{* * * *} \\
(0.01)\end{array}$ & $\begin{array}{l}-0.01 \\
(0.02)\end{array}$ \\
\hline Hi. serv. x Offshorability & & & & $\begin{array}{l}-0.01 \\
(0.02)\end{array}$ \\
\hline Lo. serv. x Offshorability & & & & $\begin{array}{l}-0.03 \\
(0.02)\end{array}$ \\
\hline Rout.nman x Offshorability & & & & $\begin{array}{l}-0.02 \\
(0.02)\end{array}$ \\
\hline Petite bourg. x Offshorability & & & & $\begin{array}{l}-0.01 \\
(0.03)\end{array}$ \\
\hline Skilled w. x Offshorability & & & & $\begin{array}{c}0.03 \\
(0.03)\end{array}$ \\
\hline Female & $\begin{array}{l}0.34^{* * * *} \\
(0.04)\end{array}$ & $\begin{array}{l}0.40^{* * * *} \\
(0.04)\end{array}$ & $\begin{array}{c}0.34^{* * *} \\
(0.04)\end{array}$ & $\begin{array}{l}0.33^{* * * *} \\
(0.04)\end{array}$ \\
\hline Age & $\begin{array}{l}-0.00 \\
(0.00)\end{array}$ & $\begin{array}{l}-0.00 \\
(0.00)\end{array}$ & $\begin{array}{l}-0.00 \\
(0.00)\end{array}$ & $\begin{array}{l}-0.00 \\
(0.00)\end{array}$ \\
\hline $\begin{array}{l}\text { Urban-rural } \\
\text { residence }\end{array}$ & $\begin{array}{c}0.04^{* * *} \\
(0.01)\end{array}$ & $\begin{array}{l}0.03^{* * *} \\
(0.01)\end{array}$ & $\begin{array}{c}0.03^{* * *} \\
(0.01)\end{array}$ & $\begin{array}{c}0.03^{* * *} \\
(0.01)\end{array}$ \\
\hline Constant & $\begin{array}{l}4.76^{* * *} \\
(0.11)\end{array}$ & $\begin{array}{l}4.33^{* * *} \\
(0.08)\end{array}$ & $\begin{array}{l}4.70^{* * *} \\
(0.11)\end{array}$ & $\begin{array}{l}4.70^{* * *} \\
(0.11)\end{array}$ \\
\hline $\begin{array}{l}\text { Observations } \\
R^{2} \\
\text { Adjusted } R^{2}\end{array}$ & $\begin{array}{l}8084 \\
0.084 \\
0.082\end{array}$ & $\begin{array}{l}8084 \\
0.054 \\
0.052\end{array}$ & $\begin{array}{c}8084 \\
0.089 \\
0.086\end{array}$ & $\begin{array}{l}8084 \\
0.090 \\
0.087\end{array}$ \\
\hline
\end{tabular}

Note: ${ }^{*} p<0.05,{ }^{* *} p<0.01,{ }^{* * *} p<0.001$. Reference categories: Class: unskilled workers; Nat. ID: Strong national identity; Education: lower. Standard errors in parentheses. 
Table 2: Explaining EU attitudes. OLS.

\begin{tabular}{|c|c|c|c|c|}
\hline & $\begin{array}{c}1 \\
\text { Class and } \\
\text { education }\end{array}$ & $\begin{array}{c}2 \\
\text { Globalization } \\
\text { variables }\end{array}$ & $\begin{array}{c}3 \\
\text { Combined } \\
\text { model }\end{array}$ & $\begin{array}{c}4 \\
\text { Interaction } \\
\text { model }\end{array}$ \\
\hline Class: Hi. serv. & $\begin{array}{c}-0.85^{* * *} \\
(0.12)\end{array}$ & & $\begin{array}{c}-0.74^{* * *} \\
(0.12)\end{array}$ & $\begin{array}{c}-0.74^{* * * *} \\
(0.14)\end{array}$ \\
\hline Class: Lo. serv. & $\begin{array}{c}-0.65^{* * * *} \\
(0.11)\end{array}$ & & $\begin{array}{c}-0.52^{* * *} \\
(0.11)\end{array}$ & $\begin{array}{c}-0.58^{* * * *} \\
(0.13)\end{array}$ \\
\hline Class: Rout.nman & $\begin{array}{c}-0.34^{* *} \\
(0.11)\end{array}$ & & $\begin{array}{c}-0.28^{* * *} \\
(0.11)\end{array}$ & $\begin{array}{c}-0.34^{* *} \\
(0.12)\end{array}$ \\
\hline Class: Petite bourg. & $\begin{array}{c}-0.64^{* * * *} \\
(0.15)\end{array}$ & & $\begin{array}{c}-0.59^{* * * *} \\
(0.15)\end{array}$ & $\begin{array}{l}-0.65^{* *} \\
(0.20)\end{array}$ \\
\hline Class: Skilled workers & $\begin{array}{c}0.10 \\
(0.13)\end{array}$ & & $\begin{array}{c}0.07 \\
(0.12)\end{array}$ & $\begin{array}{c}0.04 \\
(0.14)\end{array}$ \\
\hline Education: Medium & $\begin{array}{c}-0.35^{* * *} \\
(0.09)\end{array}$ & & $\begin{array}{c}-0.37^{\text {*** }} \\
(0.09)\end{array}$ & $\begin{array}{c}-0.38^{* * *} \\
(0.09)\end{array}$ \\
\hline Education: Higher & $\begin{array}{c}-1.41^{* * * *} \\
(0.10)\end{array}$ & & $\begin{array}{c}-1.32^{* * *} \\
(0.10)\end{array}$ & $\begin{array}{c}-1.32^{* * *} \\
(0.10)\end{array}$ \\
\hline Nat. ID: Intermediate & & $\begin{array}{c}-0.95^{* * *} \\
(0.08)\end{array}$ & $\begin{array}{c}-0.75^{* * *} \\
(0.08)\end{array}$ & $\begin{array}{c}-0.75^{* * *} \\
(0.08)\end{array}$ \\
\hline Nat. ID: Cosmopolitan & & $\begin{array}{c}-1.57^{* * * *} \\
(0.09)\end{array}$ & $\begin{array}{c}-1.38^{* * * *} \\
(0.09)\end{array}$ & $\begin{array}{c}-1.38^{* * *} \\
(0.09)\end{array}$ \\
\hline Offshorability & & $\begin{array}{c}-0.05^{* * *} \\
(0.01)\end{array}$ & $\begin{array}{l}-0.02^{*} \\
(0.01)\end{array}$ & $\begin{array}{l}-0.05 \\
(0.03)\end{array}$ \\
\hline Hi. serv. x Offshorability & & & & $\begin{array}{c}0.01 \\
(0.04)\end{array}$ \\
\hline Lo. serv. x Offshorability & & & & $\begin{array}{c}0.04 \\
(0.04)\end{array}$ \\
\hline Rout.nman x Offshorability & & & & $\begin{array}{c}0.04 \\
(0.04)\end{array}$ \\
\hline Petite bourg. x Offshorability & & & & $\begin{array}{c}0.04 \\
(0.05)\end{array}$ \\
\hline Skilled w. x Offshorability & & & & $\begin{array}{c}0.03 \\
(0.04)\end{array}$ \\
\hline Female & $\begin{array}{l}0.39^{* * * *} \\
(0.07)\end{array}$ & $\begin{array}{c}0.32^{\text {*** }} \\
(0.06)\end{array}$ & $\begin{array}{l}0.33^{* * *} \\
(0.06)\end{array}$ & $\begin{array}{c}0.33^{* * *} \\
(0.06)\end{array}$ \\
\hline Age & $\begin{array}{c}0.00 \\
(0.00)\end{array}$ & $\begin{array}{c}0.00 \\
(0.00)\end{array}$ & $\begin{array}{l}-0.00 \\
(0.00)\end{array}$ & $\begin{array}{l}-0.00 \\
(0.00)\end{array}$ \\
\hline $\begin{array}{l}\text { Urban-rural } \\
\text { residence }\end{array}$ & $\begin{array}{c}-0.07^{* * *} \\
(0.01)\end{array}$ & $\begin{array}{c}-0.07^{* * *} \\
(0.01)\end{array}$ & $\begin{array}{c}-0.05^{* * *} \\
(0.01)\end{array}$ & $\begin{array}{c}-0.05^{* * *} \\
(0.01)\end{array}$ \\
\hline Constant & $\begin{array}{c}6.56^{* * * *} \\
(0.18) \\
\end{array}$ & $\begin{array}{l}6.32^{* * *} \\
(0.14)\end{array}$ & $\begin{array}{l}6.96^{* * *} \\
(0.18)\end{array}$ & $\begin{array}{l}7.00^{* * *} \\
(0.18)\end{array}$ \\
\hline Observations & 6935 & 6935 & 6935 & 6935 \\
\hline$R^{2}$ & 0.151 & 0.127 & 0.191 & 0.191 \\
\hline Adjusted $R^{2}$ & 0.149 & 0.126 & 0.188 & 0.188 \\
\hline
\end{tabular}

Note: ${ }^{*} p<0.05,{ }^{* *} p<0.01,{ }^{* * *} p<0.001$. Reference categories: Class: unskilled workers; Nat. ID: Strong national identity; Education: lower. Standard errors in parentheses. 
Table 3: Explaining immigration attitudes. OLS.

\begin{tabular}{|c|c|c|c|c|}
\hline & $\begin{array}{c}1 \\
\text { Class and } \\
\text { education }\end{array}$ & $\begin{array}{c}2 \\
\text { Globalization } \\
\text { variables } \\
\end{array}$ & $\begin{array}{c}3 \\
\text { Combined } \\
\text { model }\end{array}$ & $\begin{array}{c}4 \\
\begin{array}{c}\text { Interaction } \\
\text { model }\end{array} \\
\end{array}$ \\
\hline Class: Hi. serv. & $\begin{array}{c}0.44^{* * *} \\
(0.10)\end{array}$ & & $\begin{array}{c}0.36^{* * *} \\
(0.09)\end{array}$ & $\begin{array}{l}0.31^{* *} \\
(0.11)\end{array}$ \\
\hline Class: Lo. serv. & $\begin{array}{c}0.45^{* * * *} \\
(0.09)\end{array}$ & & $\begin{array}{c}0.36^{* * * *} \\
(0.09)\end{array}$ & $\begin{array}{c}0.45^{* * *} \\
(0.10)\end{array}$ \\
\hline Class: Rout.nman & $\begin{array}{l}0.24^{* * *} \\
(0.09)\end{array}$ & & $\begin{array}{l}0.20^{*} \\
(0.08)\end{array}$ & $\begin{array}{c}0.21^{*} \\
(0.09)\end{array}$ \\
\hline Class: Petite bourg. & $\begin{array}{c}0.01 \\
(0.11)\end{array}$ & & $\begin{array}{l}-0.01 \\
(0.11)\end{array}$ & $\begin{array}{l}-0.03 \\
(0.15)\end{array}$ \\
\hline Class: Skilled workers & $\begin{array}{l}-0.21^{*} \\
(0.10)\end{array}$ & & $\begin{array}{l}-0.18 \\
(0.10)\end{array}$ & $\begin{array}{l}-0.21 \\
(0.11)\end{array}$ \\
\hline Education: Medium & $\begin{array}{c}0.28^{* * *} \\
(0.07)\end{array}$ & & $\begin{array}{c}0.30^{* * * *} \\
(0.07)\end{array}$ & $\begin{array}{c}0.30^{* * *} \\
(0.07)\end{array}$ \\
\hline Education: Higher & $\begin{array}{l}1.09^{* * * *} \\
(0.08)\end{array}$ & & $\begin{array}{l}1.01^{* * *} \\
(0.07)\end{array}$ & $\begin{array}{l}1.00^{* * * *} \\
(0.07)\end{array}$ \\
\hline Nat. ID: Intermediate & & $\begin{array}{l}0.79^{* * *} \\
(0.06)\end{array}$ & $\begin{array}{l}0.66^{* * *} \\
(0.06)\end{array}$ & $\begin{array}{c}0.66^{* * *} \\
(0.06)\end{array}$ \\
\hline Nat. ID: Cosmopolitan & & $\begin{array}{l}1.45^{* * *} \\
(0.07)\end{array}$ & $\begin{array}{l}1.32^{* * * *} \\
(0.07)\end{array}$ & $\begin{array}{l}1.32^{* * * *} \\
(0.07)\end{array}$ \\
\hline Offshorability & & $\begin{array}{l}0.03^{* * *} \\
(0.01)\end{array}$ & $\begin{array}{c}0.01 \\
(0.01)\end{array}$ & $\begin{array}{c}0.02 \\
(0.03)\end{array}$ \\
\hline Hi. serv. $x$ Offshorability & & & & $\begin{array}{c}0.02 \\
(0.03)\end{array}$ \\
\hline Lo. serv. x Offshorability & & & & $\begin{array}{l}-0.03 \\
(0.03)\end{array}$ \\
\hline Rout.nman x Offshorability & & & & $\begin{array}{l}-0.00 \\
(0.03)\end{array}$ \\
\hline Petite bourg. x Offshorability & & & & $\begin{array}{c}0.00 \\
(0.04)\end{array}$ \\
\hline Skilled w. x Offshorability & & & & $\begin{array}{c}0.01 \\
(0.04)\end{array}$ \\
\hline Female & $\begin{array}{l}0.13^{* *} \\
(0.05)\end{array}$ & $\begin{array}{l}0.24^{* * *} \\
(0.05)\end{array}$ & $\begin{array}{c}0.18^{* * *} \\
(0.05)\end{array}$ & $\begin{array}{c}0.18^{* * * *} \\
(0.05)\end{array}$ \\
\hline Age & $\begin{array}{c}-0.01^{* * * *} \\
(0.00)\end{array}$ & $\begin{array}{c}-0.01^{\text {**** }} \\
(0.00)\end{array}$ & $\begin{array}{c}-0.01^{* * * *} \\
(0.00)\end{array}$ & $\begin{array}{c}-0.01^{* * *} \\
(0.00)\end{array}$ \\
\hline $\begin{array}{l}\text { Urban-rural } \\
\text { residence }\end{array}$ & $\begin{array}{l}0.07^{* * * *} \\
(0.01)\end{array}$ & $\begin{array}{l}0.08^{* * * *} \\
(0.01)\end{array}$ & $\begin{array}{l}0.05^{* * *} \\
(0.01)\end{array}$ & $\begin{array}{c}0.05^{* * *} \\
(0.01)\end{array}$ \\
\hline Constant & $\begin{array}{c}3.52^{* * *} \\
(0.14) \\
\end{array}$ & $\begin{array}{l}3.57^{* * * *} \\
(0.11) \\
\end{array}$ & $\begin{array}{l}3.15^{* * *} \\
(0.13) \\
\end{array}$ & $\begin{array}{c}3.15^{* * * *} \\
(0.14) \\
\end{array}$ \\
\hline Observations & 8084 & 8084 & 8084 & 8084 \\
\hline$R^{2}$ & 0.152 & 0.151 & 0.201 & 0.202 \\
\hline Adjusted $R^{2}$ & 0.150 & 0.150 & 0.199 & 0.199 \\
\hline
\end{tabular}

Note: ${ }^{*} p<0.05,{ }^{* *} p<0.01,{ }^{* * *} p<0.001$. Reference categories: Class: unskilled workers; Nat. ID: Strong national identity; Education: lower. Standard errors in parentheses. 
